\title{
The Lawfulness of the Reconstruction Amendments
}

\author{
John Harrison $\dagger$
}

During Reconstruction the Thirteenth, Fourteenth, and Fifteenth Amendments were added to the Constitution. The circumstances under which the Reconstruction amendments were proposed and ratified were extremely unusual, and at the time serious objections were raised to the legality of the proceedings. Although for practical purposes that controversy is long over, the amendments' lawfulness remains a nagging problem. There are two important lines of objection to the amendments' adoption. One is that some or all of the southern state governments that participated in ratifying them were not legally competent to do so because of the irregular fashion in which those governments had been created. The other objection is that some or all of the southern ratifications were extorted from the states through unlawful federal threats.

This Article reviews the relevant history and discusses legal rationales under which the constitutional amendments were valid even if there were serious illegalities in the creation of the southern state governments. According to one such rationale, southern ratifications were unnecessary because the ex-Confederate states were excluded from the denominator on which the Article V supermajority is calculated. The Article concludes that this thesis is plausible but ultimately unpersua. sive. Another theory is that the identification of a state's lawful government is a political question to be decided by the political branches of the national government and ultimately by Congress, and that Congress endorsed the ratifying southern governments, thereby binding all other actors to treat those governments as lawful. The Article reviews the arguments for and against this version of the political question doctrine and regards the issue as an open one. Finally, the southern ratifications may have been effective, despite legal defects in the ratifying governments, because those governments had de facto authority and hence were able to bind their states. The legal authority of de facto governments is a familiar principle of international law that has been followed in American constitutional practice, and the Article endorses it in this context. Either the political question or the de facto government thesis must confront the argument that southern ratifications were invalid because extorted through unlawful federal threats. The Article maintains that it is doubtful whether the ratifications were so extorted, and claims that in any event Article $V$ of the Constitution does not implicitly invalidate ratifications made in the face of illegal threats.

The conclusion argues that this result, under which constitutional amendments can be validly ratified even when principles of state autonomy are violated, is nevertheless consistent with the purpose of Article $V$ and the constitutional system in general. Certainty as to the text of the Constitution is more fundamental than more substantive considerations.

Article $\mathrm{V}$ of the Constitution seeks to capture, in a bottle made of legal form, the lightning of American popular sovereignty. Its compound supermajority rules reflect the compound nature of that sovereignty.' As Madison explained, Article $\mathrm{V}$ is partly federal and partly

$\dagger$ Professor of Là and Class of 1966 Research Professor, University of Virginia. The title comes from Charles L. Black, Jr., The Lawfulness of the Segregation Decisions, 69 Yale L J 421 (1960). The connection is more than title-deep: Black was right only if the Fourteenth Amendment was validly adopted. Demian Jackson, Sarah Erickson, and Daniel Lovejoy provided excellent research assistance.

1 Amendments may be proposed by a two-thirds vote in each house of Congress, or by a convention called by Congress on the application of two-thirds of the states. They are then submitted to either the state legislatures or to ratifying conventions in each state, as Congress determines. Three-fourths of the legislatures or conventions are required to make a proposed amendment "valid to all Intents and Purposes, as Part of this Constitution." US Const Art V. 
national. ${ }^{2}$ Behind that complexity is the goal of determining whether a proposed change in the basic law has the consent of the governed.

Rules and their reasons can lose touch with one another, and Article $\mathrm{V}$ is no exception to this principle. If the stakes are low such slippage can produce puzzles that are of little practical importance. The leading example is the Twenty-seventh Amendment, proposed by the First Congress in 1789 and ratified, if ratified, in $19922^{3}$ Article V mentions no time limit; the question with respect to the Amendment is whether Article $\mathrm{V}$ is really so formalistic that it permits ratification in the absence of a contemporary consensus that would truly reflect popular consent.

Sometimes the stakes are higher, as they were in the 1860 s. According to the official documents, Congress proposed and threefourths of the state legislatures ratified three constitutional amendments of considerable importance. The Thirteenth Amendment eliminated slavery, the Fourteenth protected the freed slaves' civil rights and sought to curb the political power of the former rebels, and the Fifteenth forbade race discrimination with respect to the franchise. These issues were more important than congressional salaries.

During the turmoil of Reconstruction, one major question was whether the Article $V$ process was truly being followed. Much of the country was not represented in the Congress that proposed the Thirteenth and Fourteenth Amendments. State governments in the South were being made, unmade, and remade through extraordinary processes in which the federal government took the lead. These convulsions created doubts as to whether the resulting political organizations were truly empowered to speak for their states in ratification. Many of those governments were given strong and possibly unlawful incentives to ratify. The most blatant such threat was the statement in the first Military Reconstruction Act that the ten southern states then excluded from representation in Congress would be restored when they

2 Federalist Number 39 contains Madison's explanation:

If we try the Constitution by its last relation, to the authority by which amendments are to be made, we find it neither wholly national, nor wholly federal.... In requiring more than a majority, and particularly, in computing the proportion by States, not by citizens, it departs from the national, and advances toward the federal character: In rendering the concurrence of less than the whole number of States sufficient, it loses again the federal, and partakes of the national character.

Federalist 39 (Madison), in Jacob E. Cooke, ed, The Federalist Papers 250, 257 (Wesleyan 1961).

3 See US Const Amend XXVII (Laws varying compensation of senators and representatives do not take effect until an election for the House intervenes.).

4 See, for example, William Van Alstyne, What Do You Think About the Twenty-Seventh Amendment?, 10 Const Commen 9,14-18 (1993) (discussing doubts as to the Amendment's ratification). 
had met a series of conditions, including ratification of the Fourteenth Amendment.'

Despite the bitterness of Reconstruction, for political purposes the question of the amendments' validity was quickly settled: In 1872 both major parties accepted all three. Since then the issue has attracted almost no attention for practical or even theoretical purposes.'

American constitutional theorists now have reason to think about this issue because the most prominent of them has made it central to his work. Bruce Ackerman says that twice since the framing, the American people have changed their constitution without using the Article V process. The second time, in the 1930 s, they dispensed with the written amendments contemplated by that provision. ${ }^{8}$ But the first time, in the 1860 s, they used a procedure that resembled but was not Article $\mathrm{V}$ to produce three authoritative texts that had the appearance, but only the appearance, of Article $\mathrm{V}$ amendments.' Hyperformalists and hypertextualists, says Ackerman, cannot account for the Thirteenth and Fourteenth Amendments, which became part of the fundamental law through a process inconsistent with the formal rules of Article V's text."

This Article is concerned specifically with two objections to the ratification process. First is the claim that some or all of the southern state legislatures that ratified the Thirteenth and Fourteenth Amendments lacked the legal power to act for their states. Second is that

5 See Act of March 2,1867, ch CLIIL, § 5, 14 Stat 428, 429 (enumerating requirements for admission of senators and representatives).

6 See Donald Bruce Johnson, ed, 1 National Party Platforms 41, 46-47 (Illinois 1978) (Democratic and Republican platforms of 1872).

7 The Supreme Court cast a sidelong glance at these problems in Coleman v Miller, 307 US 433, 451-56 (1939) (Kansas), and its companion case, Chandler v Wise, 307 US 474, 477-78 (1939) (Kentucky), which refused to reach the merits of two challenges to state ratification of the proposed Child Labor Amendment.

The leading law review articles on this subject are Ferdinand F. Fernandez, The Constitutionality of the Fourteenth Amendment, 39 S Cal L Rev 378, 379, 385 (1966) (defending the ratification process); Joseph L. Call, The Fourteenth Amendment and Its Skeptical Background, 13 Baylor L Rev 1, 1, 16-17 (1961) (criticizing the ratification process); Pinckney G. McElwee, The 14th Amendment to the Constitution of the United States and the Threat That It Poses to Our Democratic Government, 11 SC L Q 484, 484, 510-13 (1959) (criticizing the process); and Walter J. Suthron, Jr., The Dubious Origin of the Fourteenth Amendment, 28 Tulane L Rev 22, 40-44 (1953) (raising but not answering questions about the ratification process).

8 Bruce Ackerman, 2 We the People: Transformations 23-26 (Belknap 1998) (discussing similarities and differences between Reconstruction and the New Deal).

9 "While the Reconstruction Republicans repudiated the federalist premises of the Founding, they memorialized their revolutionary reforms by placing them in legal packages that resemble Article Five amendments - bearing the numbers XIII and XIV and placing themselves in sober sequence with other amendments of less uncertain pedigree." Id at 269.

10 In a chapter titled "Formalist Dilemmas," Ackerman explains: "This book's central target is hypertextualism - the naive, but orthodox, view that Article Five provides a framework within which modern lawyers can explain all valid amendments since the Founding." Id at 115. 
those ratifications, even if made by valid state legislatures, were void because they were made under unlawful political pressure from the national government." I maintain that the proposal and ratification of the Reconstruction amendments was legally effective under Article $\mathrm{V}^{12}$ The words "legally effective" are chosen carefully, for the argu-

11 The debate over the amendments includes other issues, but they are not actually very difficult. One question is whether the Congresses that proposed the amendments were themselves valid. The objection is that they did not represent the entire Union. Both houses of the Thirty-eighth and Thirty-ninth Congresses, however, contained an absolute majority of the Senate and House even if the South was counted in the denominator. Hence each house had a quorum to do business under the Constitution. See US Const Art I, $\$ 5, \mathrm{cl} 1$ (defining quorum as a majority). The quorum requirement does not distinguish between votes on constitutional amendments and other business. Whether the houses should have acted on any major questions, including a constitutional amendment, while a substantial part of the country was unrepresented was a question of policy, not power.

Next, several of the southern states that ultimately ratified the Fourteenth Amendment did so only after their legislatures had earlier considered ratification without ratifying. See 1 USC LXII-LXIII (1994) (listing ratifications and prior rejections). This raises the longstanding question whether a state may ratify after having once rejected. See, for example, Coleman, 307 US at 450 (refusing to decide whether a state that has once rejected may then ratify). Although the question is old, it seems easy to me. Article $V$ refers only to ratification. It does not mention, does not attach any consequences to, and does not define, rejection. It does not distinguish, for example, among cases in which one house of the legislature votes down a motion to ratify and the other house does not act, cases in which neither house acts at all (perhaps because the amendment clearly is doomed in that state), and cases in which both houses defeat motions to ratify. The inference is that a state's options under Article $V$ are ratification and non-ratification.

Third is a more difficult question: whether a ratification may be rescinded. Two northern legislatures, Ohio's and New Jersey's, adopted resolutions purporting to rescind their ratifications of the Fourteenth Amendment. See 1 USC LXII-LXIII (listing ratifications and purported rescissions). Whether a state lawfully may rescind depends on whether ratification is an ongoing choice, so that a state may move in and out of it, or a once-and-for-all decision as to which the trap slams shut and stays shut. Michael Stokes Paulsen addresses this issue in developing a theory of Article V based on the model of legislation. Michael Stokes Paulsen, A General Theory of Article V: The Constitutional Lessons of the Twenty-seventh Amendment, 103 Yale L J 677, 722-23 (1993). It is not necessary to resolve this question, however, because if the southern ratifications were valid, Ohio and New Jersey were not needed; and if the southern ratifications were invalid, Ohio and New Jersey would not make up the difference. On July 28,1868 , Secretary of State Seward proclaimed the Fourteenth Amendment ratified, listing thirty ratifications, which included Ohio and New Jersey. William H. Seward, Proclamation No 13, July 28, 1868, 15 Stat Appendix $708,708-10$. In July 1868 , there were thirty-seven states in the Union, see 1 USC LXIII, and twenty-eight is more than three-fourths of thirty-seven.

12 Although this Article is about all three Reconstruction amendments, it will be necessary to discuss in detail only two, the Thirteenth and the Fourteenth. The Fifteenth Amendment was proposed by the Third Session of the Fortieth Congress, which had members from substantially more states than the Congresses that proposed the two earlier amendments. Secretary of State Hamilton Fish promulgated it on March 30,1870, listing thirty ratifying states, which was one more than necessary. Hamilton Fish, Proclamation No 10, March 30, 1870, 16 Stat 1131, 1131. The legislature of New York, which was on Fish's list, had passed a resolution purporting to withdraw its ratification. Id. All of the southern ratifications came from governments established under congressional reconstruction. Three of the southern ratifications came from states that had not yet been declared entitled to representation in Congress (Mississippi, Texas, and Virginia), and one came from a state that had been declared eligible but then treated by Congress as possibly ineligible (Georgia). See id (listing ratifying states); note 184 (listing dates of readmission). The objections to the Fourteenth and Fifteenth Amendments are thus the same, and if those objec- 
ment is formalistic: it does not deny that during Reconstruction Article $\mathrm{V}$ badly served its purpose of balancing the federal and national principles. ${ }^{13}$ Moreover, I will admit the possibility that the amendment process included illegal acts, some of them by Congress. Nevertheless, I will assert that the amendments satisfied the Constitution's explicit and implicit requirements for validity. Those requirements do not implement every plausible description of Article V's purposes and they tolerate some illegalities.

Part I presents yet another brief history of Reconstruction, this one focused on the ratification process and in particular on the changes in southern state governments. That Part also discusses the Republicans' responses to the legal objections they faced. Part II then presents three plausible theories under which the amendments were validly ratified. One claims that massive disruptions to a state's government can temporarily remove that state from the total number of which three-fourths are needed for ratification, thus for a while taking it out of the Article $\mathrm{V}$ denominator without permanently taking it out of the Union. I find this thesis plausible but unpersuasive, although others may be more persuaded. The other two theories assert that legally doubtful state governments nevertheless may perform legally effective acts, either because the legal doubts are resolved by recognition from the federal political branches or because in general a government de facto may bind the state for which it acts despite defects in its claim to power. I think the first rationale arguable but very difficult ultimately to assess, while I think the second is correct. Both theories that include all the states in the denominator must deal with the claim that Article $\mathrm{V}$ does not count ratifications obtained through federal political coercion. I suggest that the problem posed by coercion is not fatal. ${ }^{14}$ Part III then moves away from the detail and explains how it is

tions are not fatal to the Fourteenth they are not fatal to the Fifteenth either.

13 That is the heart of Ackerman's argument that the ratification process was inconsistent with Article V. "[I]t was the Reconstruction Republicans, not the New Deal Democrats, who first established that We the People could speak through national institutions and demand that the states accept the primacy of American citizenship." Ackerman, 2 We the People at 269 (cited in note 8).

14 All three theories share two important features: they make it unnecessary to decide whether Congress acted fully lawfully when it displaced ten existing southern governments through the Military Reconstruction Acts, and they are immune to the argument that the validity of the Thirteenth Amendment implies the invalidity of the Fourteenth, and vice versa. The latter argument arises naturally because in the first Military Reconstruction Act Congress declared ten existing southern governments to be provisional only, see Act of March 2, 1867, § 6, 14 Stat at 429 , even though several of those state legislatures had participated in ratifying the Thirteenth Amendment, see 1 USC LXII (listing ratifications). President Johnson pointed to this problem in his veto message. "If this assumption of the bill be correct, [the ten illegal legislatures'] concurrence can not be considered as having been legally given, and the important fact is made to appear that the consent of three-fourths of the States - the requisite number-has not been constitutionally obtained to the ratification of [the Thirteenth Amendment]." Andrew Johnson, Veto 
sensible to read Article $\mathrm{V}$ so that it is so formalistic and so tolerant of possibly illegal acts.

After describing the many problems confronting the Thirteenth and Fourteenth Amendments, Ackerman asks, "Is there any way out of the textualist wilderness?"15 This Article is a voice that cries from that wilderness. It says that the path of the Reconstruction amendments, although in many ways winding, was legally straight.

\section{HISTORY}

A. The Adoption of the Thirteenth and Fourteenth Amendments

Part I.A's summary of political and legal developments in the $1860 \mathrm{~s}$ is divided into three parts. It first treats the period from the beginning of secession through the proposal of the Thirteenth Amendment, a period during which loyalist regimes were erected in four seceded states. Then, at the cusp between civil war and reconstruction, Part I.A.2 pauses to set out the leading legal theories about what had happened to the Union and what was needed to put it back together again. Those theories formed the basis for the events recounted in the next part, which describes Reconstruction by President Johnson and Congress, focusing on the legal status of the southern state governments and the progress of the Thirteenth and Fourteenth Amendments.

1. Southern state governments during the war.

Shortly after the presidential election of 1860 , southern states began to secede. South Carolina, home of the fire-eaters, took the lead and set the procedural precedent under which the legislature would call a convention on the issue. By the time Lincoln took office on March 4, 1861, the states of the lower South had seceded, formed a provisional Confederate government, and taunted the Yankees by inaugurating their President before Lincoln could take the helm of a shrinking Union. ${ }^{16}$

Through March and into April of 1861, the great questions of union or disunion, war or peace, hung in the balance. Probably the crucial weight on the scale was Virginia, without which the Confederacy

Message, Mar 2, 1867, in James D. Richardson, ed, 6 A Compilation of the Messages and Papers of the Presidents 1789-1897 448, 508 (GPO 1897).

15 Ackerman, 2 We the People at 113 (cited in note 8).

16 The secession of the lower South is described in David M. Potter, The Impending Crisis: 1848-1861 490-99 (Harper \& Row 1976). South Carolina's convention adopted its ordinance of secession on December 20, 1860, Mississippi's convention did so on January 9, 1861, Florida's on January 10, Alabama's on January 11, Georgia's on January 19, Louisiana's on January 26, and Texas's on February 1. See id at 492, 498. 
was not much of a country. As long as the federal government did not seek to coerce the states, the Virginia secessionists were unable to achieve a majority. When Lincoln responded with force to the attack on Fort Sumter, however, the vote in Virginia went in favor of secession. ${ }^{17}$ Arkansas followed on May 6, North Carolina on May $21 .^{18}$ Tennessee, which was bitterly divided, followed a slightly different path, effectively joining the Confederacy on May 7, although the people did not vote in favor of secession until June $8 .{ }^{19}$ By the middle of May 1861 eleven states were substantially controlled by authorities that looked to the Confederacy as their federal government. ${ }^{20}$

The Union as Americans had known it had collapsed.

Reconstruction began in Virginia before that state's secession was even complete. After the Virginia convention voted to secede on April 17 , a series of mass meetings in the northwest part of the state resulted in a convention that met in Wheeling on May 13, 1861. ${ }^{21}$ This first Wheeling convention denounced secession, urged the people to vote against it in the coming referendum, and called for another convention of Unionists to meet in June should the statewide vote go for secession. When disunion prevailed, Unionists employed irregular means to select delegates to a second meeting to convene in Wheeling on June $11 .^{23}$ That body assumed the power of a convention of the

17 On February 4, 1861, Virginia elected a convention to deliberate on the crisis. See id at 505. Advocates of immediate secession fared poorly in the election of delegates, and the people endorsed a requirement that secession be submitted to a referendum. See id at 507-08. The convention first met on February 18, but did not vote in favor of secession until April 17, soon after the attack on Fort Sumter. See Charles H. Ambler, Francis H. Pierpont: Union War Governor of Virginia and Father of West Virginia 79-80 (North Carolina 1937).

18 Edward McPherson, The Political History of the United States of America, During the Great Rebellion 4-5 (Philp \& Solomons 1864) (listing actions taken by seceding states' legislatures).

19 James Walter Fertig, The Secession and Reconstruction of Tennessee 20, 26, 27 (Chicago 1898). On February 9,1861 , in a referendum called by the legislature, Tennessee's voters rejected a convention call and voted against secession. Id at 19-20. The Governor and legislature, however, were pro-secession, and a committee appointed by the legislature entered into negotiations with the Confederate States. Id at 23-24. On May 7 the legislature ratified a military alliance with the Confederacy, having the previous day provided for a referendum on secession. Id at 24 25 . The referendum, conducted after the state had in effect seceded, approved that act by a vote of 104,913 to 47,238 . Id at 27.

20 McPherson, Rebellion at 2-6 (cited in note 18) (listing the Confederate states and their respective time lines for seceding from the Union).

21 See James G. Randall, Constitutional Problems Under Lincoln 438 (Appleton 1926) (explaining the division of Virginia into Virginia and West Virginia). Members of the May convention in Wheeling generally had not been elected in any regular fashion, so it was itself a mass meeting more than a constituent body. See id at 438-39.

22 Id at 439.

23 Id at 440-43. According to Randall, delegates "were chosen in various ways, sometimes by mass meeting, sometimes by the county committee [of safety organized by local Unionists], sometimes apparently by self-appointment. There was no popular election in the true sense." Id at $440-41$. 
people of Virginia and reorganized the state government, acting to replace the officers who had taken the state into the Confederacy. ${ }^{24}$ It elected as Governor Francis H. Pierpont, a western Virginian and ardent Unionist, and arranged for the creation of a legislature to replace the body sitting in Richmond. ${ }^{25}$ On June 21, 1861, Governor Pierpont wrote to Abraham Lincoln, calling on the President to perform his constitutional duty and suppress the rebellion and violence that had overcome much of Virginia.

In July 1861 the new legislature met at the "Restored Virginia" capital of Wheeling in a special session called by Governor Pierpont. ${ }^{27}$ It elected two Unionist Senators, Waitman T. Willey and John S. Carlile, to replace the secessionists James M. Mason and R.M.T. Hunter. On July 13 their credentials were presented to the Senate by a senator from Tennessee, Andrew Johnson, and enthusiastically accepted by the Republican majority despite some doubts about the Wheeling regime. ${ }^{29}$ In similar fashion the House seated four representatives from Virginia congressional districts controlled by the Unionist authorities.

Pierpont and his colleagues became even more of a rump once they had assisted in the creation of West Virginia. After years as a permanent minority in the state's councils, western Virginians seized the opportunity provided by their nominal control of the government of Virginia and sought a permanent solution. A convention met at Wheeling, organized a new state, sought and obtained the Pierpont legislature's permission to subdivide the Old Dominion, and applied

24 Id at $443-44$.

25 Id at 445-50. Governor Pierpont is emblematic of the confused events in Virginia, and the strange origins of West Virginia, in that it is not clear how to spell his name. Francis Harrison Pierpont spelled his own last name Peirpoint until 1881, when he decided that his father, Francis Peirpoint, and his relatives, had been spelling it incorrectly for many decades. See Ambler, Pierpont at 3 (cited in note 17). (The middle name came from the elder Peirpoint's former commander, William Henry Harrison. Id.) In keeping with the Governor's wishes I will refer to him as Pierpont.

26 Ambler, Pierpont at 388 (cited in note 17). Under Article IV of the Constitution, the United States is to protect each state against invasion "and on Application of the Legislature, or of the Executive (when the Legislature cannot be convened) against domestic Violence." US Const Art IV, $\S 4$. In keeping with the Constitution, Governor Pierpont recited that "large numbers of evil-minded persons" were "making war on the loyal people of the State"; he could not convene the legislature in time to act in the premises; and he requested that the President "furnish a military force to aid in suppressing the rebellion and to protect the good people of this Commonwealth from domestic violence." Ambler, Pierpont at 388. In answer to Pierpont's letter, Secretary of War Simon Cameron explained that the President had directed him to tell the Governor "that a large additional force will soon be sent to your relief." Id. Eventually, under the command of Ulysses S. Grant, that force did relieve Governor Pierpont.

27 Randall, Constitutional Problems at 449 (cited in note 21).

28 Id at 451.

29 See Cong Globe, 37th Cong, 1st Sess 103-09 (July 13, 1861) (debate and vote). 
to Congress for admission to the Union." Once again, the Pierpont government's doubtful claim to represent a majority of Virginians was discussed in Congress and once again the decision was to accept the loyal minority as speaking for the whole. ${ }^{32}$ President Lincoln sought his cabinet's advice before signing the legislation, then did so despite an opinion from Attorney General Bates that the Wheeling legislature did not lawfully represent all of Virginia. ${ }^{33}$ In June 1863 West Virginia entered the Union. ${ }^{34}$ Pierpont, although a westerner, moved to Alexandria, where he and his associates more or less governed those parts of the state under Union occupation.

31 Randall, Constitutional Problems at 451-53 (cited in note 21). Article IV provides "New States may be admitted by the Congress into this Union; but no new State shall be formed or erected within the Jurisdiction of any other State; nor any State be formed by the Junction of two or more States, or Parts of States, without the Consent of the Legislatures of the States concerned as well as of the Congress." US Const Art IV, § 3.

32 Randall, Constitutional Problems at 454-56 (cited in note 21). One opponent of partition was Representative Joseph Segar, who had been elected from counties in eastern Virginia that were under Union control. Segar argued that admitting West Virginia would leave Virginia itself with no loyal government at all, whereas the Wheeling organization was a nucleus around which Unionists would collect. Cong Globe, 37th Cong, 3d Sess 55 (Dec 10, 1862). Another participant in the congressional decision, Representative James G. Blaine of Maine, later discussed the debate in detail in his memoir. See James G. Blaine, 1 Twenty Years of Congress: From Lincoln to Garfield 457-69 (Henry Bill 1884). Blaine described a noteworthy exchange between Thaddeus Stevens and John Bingham in the House. Stevens said that it was absurd to treat the Wheeling legislature as the legislature of Virginia, but that he was prepared to admit West Virginia, not under the Constitution, but under the law of war. Bingham replied that the proceedings were lawful: the rebel majority, who had abandoned their political rights under the Constitution, could not be allowed to keep the loyal minority from exercising the rights they retained, so in this situation the minority was entitled to speak for the state. See id at 464-65 (reviewing the Stevens-Bingham debate); Cong Globe, 37th Cong, 3d Sess 50 (Dec 9, 1862) (remarks of Rep Stevens); id at 56-59 (Dec 10,1862) (remarks of Rep Bingham).

33 Lincoln called for the written opinions of his department heads and the Attorney General, and the Cabinet divided evenly on the question. Secretary of State Seward, Secretary of the Treasury Chase, and Secretary of War Stanton favored the bill, while Attorney General Bates, Postmaster General Blair, and Secretary of the Navy Welles were opposed. See Randall, Constitutional Problems at 457-59 (cited in note 21); 10 Op Atty Gen 426, 435 (Dec 27,1862) (Edward Bates, AG). At the Cabinet meeting President Lincoln stated that the disloyal could not be treated as the political equals of those who maintained their loyalty, and that while he was troubled by the dismemberment of Virginia he thought it a necessary war measure. See John G. Nicolay and John Hay, eds, 8 Complete Works of Abraham Lincoln 157-60 (Tandy new and enl ed 1905). In the end, Lincoln signed the bill, see Randall, Constitutional Problems at 460, which conditioned admission of West Virginia on a state constitutional amendment providing for gradual emancipation of slaves in the new state, see Act of December 31, 1862, ch VI, 12 Stat 633, 634.

34 Abraham Lincoln, Proclamation, Apr 20, 1863, in Richardson, ed, 6 Messages and Papers of the Presidents at 167 (cited in note 14) (taking effect in sixty days).

35 Randall, Constitutional Problems at 461-63 (cited in note 21). Of particular interest for this Article is restored Virginia's representation in Congress. Two Virginia senators elected by the Wheeling legislature were seated in July 1861. See Cong Globe, 37th Cong, 1st Sess 103-09 (July 13,1861 ) (debate and vote concerning the seating of Waitman T. Willey and John S. Carlile).

In the House, four Virginians were seated in the Thirty-seventh Congress, which sat from 1861 to 1863 . Three were from what became West Virginia and one from eastern parts of the state that were partially under the control of the Union. See Kenneth C. Martis, The Historical Atlas of the United States Congressional Districts, 1789-1983 94-95 (Free Press 1982) (listing the 
While Virginians engaged in genuine self-reconstruction, creating a loyal government with no official guidance from Washington City, loyalists in other seceded states were given more of a push from the center. By a proclamation of December 8, 1863, President Lincoln announced the terms on which he would recognize loyalist political organizations as state governments entitled to the benefits of Article IV. ${ }^{36} \mathrm{He}$ offered a pardon to most participants in the rebellion who would take and faithfully keep an oath to support the Constitution along with specified Union war measures. ${ }^{37}$ Under Lincoln's plan a new state government could be formed by a group of oath-takers eligible to vote under state law as it stood at the time of secession if that group amounted to at least one-tenth of the votes cast in the 1860 presidential election. ${ }^{38}$ If republican in form, such a government, in the President's view, would be entitled to the Article IV guarantees. ${ }^{39}$ Loyalists would seek to take the President up on his offer by forming new governments in Louisiana, Arkansas, and Tennessee.

Thanks to Union naval superiority, major portions of the population and some of the territory of Louisiana came into federal hands early in the war. ${ }^{40}$ The capture of New Orleans brought Louisiana's

membership of the Thirty-seventh Congress and displaying maps of their respective districts). The Representative from eastern Virginia was Joseph Segar, from a district that contained the Eastern Shore. See id. Lewis McKenzie claimed a seat from the Alexandria district, Cong Globe, 37th Cong, 3d Sess 602 (Jan 29, 1863) (credentials presented), but he was not seated, id at 1037 (Feb 17,1863) (credentials rejected). No Virginian was seated by the House of Representatives in the Thirty-eighth, Thirty-ninth, or Fortieth Congress. See Martis, Historical Atlas at 97-101 (showing the membership of the Thirty-eighth, Thirty-ninth, and Fortieth Congresses and maps of their districts).

36 Lincoln, Proclamation, Dec 8, 1863, in Richardson, ed, 6 Messages and Papers of the Presidents at 213-15 (cited in note 14).

37 The oath was:

$\mathrm{I}, \longrightarrow,-$, do solemnly swear, in presence of Almighty God, that I will henceforth faithfully support, protect, and defend the Constitution of the United States and the Union of the States thereunder; and that I will in like manner abide by and faithfully support all acts of Congress passed during the existing rebellion with reference to slaves, so long and so far as not repealed, modified, or held void by Congress or by decision of the Supreme Court; and that I will in like manner abide by and faithfully support all proclamations of the President made during the existing rebellion having reference to slaves, so long and so far as not modified or declared void by decision of the Supreme Court. So help me God.

Id at 213-14. Excluded from the pardon offer were various specified categories of Confederate leaders, those who had broken an earlier oath to the United States, and those who had violated the laws of war with respect to federal military personnel who were "colored persons, or white persons in charge of such." Id at 214.

38 Id.

39 Id. To avoid misunderstanding, he explained, "it may be proper to further say that whether members sent to Congress from any State shall be admitted to seats constitutionally rests exclusively with the respective Houses, and not to any extent with the Executive." Id at 215.

40 In the early morning of April 24, 1862, United States Navy forces under Admiral David Farragut began an assault in which they fought their way past the Confederate forts and vessels 
First and Second Congressional Districts largely under Union control, and in December 1862 special elections were held to fill out the remaining term of the Thirty-seventh Congress. ${ }^{41}$ (That term would end on March 3,1863. ${ }^{42}$ ) After considerable debate, the House seated the Louisiana claimants in February 1863; they would be the last from Louisiana until 1868 . $^{43}$

Louisiana was thus one of the targets of Lincoln's program of creating loyal state governments, a program that would be implemented by General Nathaniel P. Banks, commanding the Department of the Gulf. ${ }^{44}$ On December 24, 1863, the President instructed Banks to "give us a free State reorganization of Louisiana in the shortest possible time. ${ }^{.45}$ Banks conducted two elections in early 1864 . The first, to select state-wide officers under the Louisiana Constitution of 1852, was held in February 1864; the Governorship was won by Michael Hahn, a moderate leader of the Free-State party. ${ }^{46}$ Then in March General Banks conducted an election for delegates to a constitutional convention. ${ }^{47}$ The convention drafted a constitution that abolished slavery but restricted the suffrage to whites while authorizing the legislature to extend it to non-whites on the basis of military service, taxpaying, or intellectual fitness. ${ }^{48}$ The Free-State Constitution was rati-

defending New Orleans. J.G. Randall and David Donald, The Civil War and Reconstruction 44546 (Raytheon 2d ed 1969). Once Farragut's ships had taken command of the river and had the city under their guns, the Confederate troops withdrew. Id at 446 . A full occupying force under General Benjamin Butler, whose harsh rule would become a cause célèbre in the South, landed on May 2, and New Orleans was firmly under Union control. Id.

41 See Joe Gray Taylor, Louisiana Reconstructed, 1863-1877 16-17 (LSU 1974).

42 See Cong Globe, 37th Cong, 3d Sess 1553 (Mar 3, 1863) (adjourning).

43 Taylor, Louisiana Reconstructed at 16-17 (cited in note 41). See also Cong Globe, 37th Cong, 3d Sess 1031-35 (Feb 17, 1863) (debate on seating Louisiana claimants); id at 1036 (both claimants declared entitled to seats, Hahn sworn in); id at 1208 (Feb 23, 1863) (Flanders sworn in).

44 See Taylor, Louisiana Reconstructed at 18-25 (cited in note 41) (describing Banks's actions to bring Louisiana back into the Union).

45 Id at 25.

46 See id at 27-30 (reviewing the electoral contest). The Free-State grouping followed a political line between that of the Conservative Unionists, who struck some as Copperheads, and the Radicals. See id. As Taylor notes, the poll in this election was more than 20 percent of that cast in the 1860 presidential election, id at 30 , indicating that Union-controlled Louisiana easily could satisfy Lincoln's 10 percent requirement, id at 29.

47 Id at 42 . Louisiana's 1852 constitution extended the suffrage to every free white male citizen who had resided in the state for one year and in the parish in which he voted for six months. See La Const of 1852 Art 10 (superseded 1864). Banks's election call employed this rule with the further qualification of Lincoln's amnesty oath. Taylor, Louisiana Reconstructed at 42 (cited in note 41 ). The constitutional convention's apportionment rule, however, differed from that of the legislature under the 1852 constitution in that the convention was apportioned according to the white population, which reduced Louisiana's version of the Slave Power. See id at 43 (noting that each delegate represented two thousand white inhabitants).

48 See La Const of 1864 Arts 1, 2 (superseded 1868) (abolishing slavery); id Arts 14, 15 (providing suffrage rules). 
fied by a majority of the votes cast in an election on September 5 , 1864. ${ }^{49}$ The new legislature met in October 1864 and elected two United States Senators, R. King Cutler and Charles Smith, the latter to a term that would expire in March $1865 .{ }^{50}$ When it convened again in January 1865, the legislature elected Governor Hahn to the term that would begin in March of that year. ${ }^{51}$ Members of Congress for the term to expire in March 1865 had been chosen at the September 1864 election. ${ }^{52}$ None of the Louisianans was seated, although the Senate Judiciary Committee had reported favorably as to the senatorial claimants.

Arkansas followed a broadly similar path, although apparently with more spontaneous activity by local Unionists. Little Rock and Fort Smith fell to the United States in September 1863, and in October loyalists held mass meetings in those cities. ${ }^{54}$ In response to Lincoln's 10 percent proclamation, they organized a series of meetings to elect delegates to a convention that met in Little Rock in January $1864 .^{55}$ The convention drafted a constitution that abolished slavery but retained the all-white franchise. ${ }^{56}$ On President Lincoln's instructions, the federal military registered voters and conducted an election in the middle of March. ${ }^{57}$ According to the official returns, the constitution was ratified by the lopsided vote of 12,179 in favor and 226 against. ${ }^{58}$

49 The vote was 6,836 in favor and 1,566 against, which satisfied Lincoln's 10 percent requirement. Taylor, Louisiana Reconstructed at 52 (cited in note 41).

50 Id at 54.

51 Id.

52 See id at 53-54 (describing the election of representatives).

53 On December 6,1864 , the credentials of the Louisiana senatorial claimants were referred to the Senate Judiciary Committee. Cong Globe, 38th Cong, 2d Sess 8 (Dec 8, 1864). On February 18, 1865, the committee's Chairman, Lyman Trumbull of Illinois, introduced as the committee's report a resolution recognizing the reconstructed regime as the legitimate government of Louisiana, with the implication that the claimants' credentials were valid. See id at 903 (Feb 18, 1865). The resolution was debated at some length, see id at 1061-70 (Feb 24, 1865); id at 1091-99 (Feb 25, 1865); id at 1101-11 (Feb 25, 1865), and not adopted, see id at 1126-29 (Feb 27, $1865)$.

The day before Trumbull's favorable report on the Louisiana claimants, the House Committee on Elections had reported favorably on two claimants each from Louisiana and Arkansas, see id at 870 (Feb 17, 1865), but they were not seated either, see Taylor, Louisiana Reconstructed at 54 (cited in note 41) (Louisiana's elected officials); Carl H. Moneyhon, The Impact of the Civil War and Reconstruction on Arkansas: Persistence in the Midst of Ruin 165 (LSU 1994) (Arkansas's elected officials).

54 See Moneyhon, Impact of the Civil War at 159 (cited in note 53).

55 Id at $159-61$.

56 See Ark Const of 1864 Art V, $\S 1$ (superseded 1868) (abolishing slavery); id Art IV, $\S 2$ (establishing suffrage for free white male citizens).

57 Moneyhon, Impact of the Civil War at 162-63 (cited in note 53).

58 Id at 164. Substantial parts of the state were still under Confederate control. 
When senators and representatives elected under the new regime presented their credentials in 1864 they were rejected. ${ }^{59}$ Two objections were especially important: that the loyalist government did not represent a majority of the people of Arkansas and that its authority was tainted by the President's role in creating it. Senator Saulsbury of Delaware combined the two arguments when he complained that the Arkansas claimants came from "a rotten borough government established by Abraham Lincoln, and not by the people of Arkansas.",60

Tennessee was last of the three to organize under Lincoln's plan. In March 1862, President Lincoln persuaded Senator Andrew Johnson to serve as military governor of those parts of the state under Union control. ${ }^{61}$ On January 9,1865 , a loyalist convention, which was really a mass meeting in that many of its members had been chosen irregularly, convened in Nashville. ${ }^{62}$ Governor (and Vice President-elect) Johnson urged the convention to take action even though its origins were questionable; he explained that "[a]ny man may draw up resolutions, which when ratified by the people become law." ${ }^{\circ 3}$ The delegates proposed a constitutional amendment abolishing slavery and an accompanying schedule providing for the transition back to civilian rule; these were submitted to a referendum on February $22,1865 .^{64}$ The schedule also regulated suffrage for the ratification referendum, requiring that voters take a titanium-clad loyalty oath. ${ }^{65}$ The proposals

$59 \quad$ Id at 165.

60 Cong Globe, 38th Cong, 1st Sess 2903 (June 13, 1864). In similar fashion Senator Charles Sumner argued that the new Arkansas government was revolutionary in character and, worse yet, could be traced to a military order. See id at 2897.

61 Thomas B. Alexander, Political Reconstruction in Tennessee 14-15 (Vanderbilt 1950).

62 See id at 16-17 (describing the delegates).

63 Fertig, Secession and Reconstruction 57 (cited in note 19) (internal quotation omitted) (quoting Johnson's speech to the convention).

64 Ben Perley Poore, ed, 2 The Federal and State Constitutions, Colonial Charters, and Other Organic Laws of the United States $1692 \mathrm{n}$ * (GPO 2d ed 1878). The amendment abolished slavery and denied to the legislature the power to make any law recognizing the right of property in man. See Tenn Const of 1834 Amend I (superseded 1870). The schedule went on at greater length. It declared the ordinance of secession treasonous, null, and void, then it generally nullified actions of the Confederate State government, and ratified the appointments made by Governor Johnson to state offices. Id Schedule, \$§ 2-7.

65 The Tennessee delegates required voters to take the following oath:

I solemnly swear that I will henceforth support the Constitution of the United States, and defend it against the assaults of all its enemies; that $\mathrm{I}$ am an active friend of the Government of the United States, and the enemy of the so-called Confederate States; that I ardently desire the suppression of the present rebellion against the Government of the United States; that I sincerely rejoice in the triumph of the armies and navies of the United States, and in the defeat and overthrow of the armies, navies, and of all armed combinations in the so-called Confederate States; that I will cordially oppose all armistices or negotiations for peace with rebels in arms, until the Constitution of the United States, and all laws and proclamations made in pursuance thereof, shall be established over all the people of every State and Territory embraced within the national Union; and that I will heartily aid and assist the loyal people in whatever measures may be adopted for the attainment of 
were ratified in February. ${ }^{66}$ On March 4, 1865, in an election also conducted under that oath requirement, a Governor and legislature were chosen. ${ }^{67}$ With Tennessee in the fold, four states had at least the show of loyalist governments, three of them organized under Lincoln's proposal.

That proposal had not gone down well with everyone in Congress. Both substance and turf were at issue, and in 1864 the first session of the Thirty-eighth Congress set about considering its own plan. The result was the Wade-Davis bill, principally sponsored by Senator Benjamin Wade of Ohio and Representative Henry Winter Davis of Maryland, both Republicans. ${ }^{68}$ Their bill authorized the President to appoint for each seceded state a provisional governor who would administer state law while a new government was formed. ${ }^{69}$ Creation of such a government would require an oath of allegiance from a majority of white male citizens. ${ }^{70}$ With such oaths in place, a constitutional convention could be elected by voters who had not held Confederate office or voluntarily served in its military. ${ }^{71}$ Should the convention draft and the people ratify a constitution that abolished slavery, repudiated the Confederate war debt, and disenfranchised former Confederate officials, the state, upon a further affirmative vote of Congress, would be entitled to senators and representatives. ${ }^{72}$

Proponents of congressional primacy with respect to Reconstruction maintained that it derived from the Guarantee Clause of Article IV and the relation between executive and legislative power. ${ }^{73}$ While the President could carry out the law, and in doing so must make some legal judgments, ultimately it was up to Congress to formulate the applicable rules and conclusively determine the federal government's position on the status of state governments. ${ }^{74}$ President Lincoln took no action when the Wade-Davis bill was presented to him with under an hour (and hence less than ten days (Sundays excepted)) to go in

those ends; and further, that I take this oath freely and voluntarily and without mental reservation: So help me God.

Poore, ed, 2 Federal and State Constitutions at 1693 (cited in note 64).

66 See id at $1692 \mathrm{n} *$.

67 Tenn Const of 1834 Amend I, Schedule, $\$ 8$ (superseded 1870) (setting forth the election date).

68 See HR 244, 38th Cong, 1st Sess (Feb 15, 1864), reprinted in Richardson, ed, 6 Messages and Papers of the Presidents at 223-26 (cited in note 14).

69 Id \& 1 .

70 Id $\S 2$.

71 Id $\$ \$ 2-4$.

72 Id \$\$ 7-8.

73 See Cong Globe, 38th Cong, 1st Sess Appendix 82-85 (Mar 22, 1864) (remarks of Rep Davis).

74 See id. 
the congressional session. ${ }^{75}$ Lincoln did issue a pocket veto proclamation explaining that he was "unprepared to declare that the free State constitutions and governments already adopted and installed in Arkansas and Louisiana shall be set aside and held for naught." ${ }^{, 6}$ But he was flexible: if the loyal people of a state liked the Wade-Davis formula better than they liked his, he would support them by appointing military governors who would proceed in accordance with the bill."

When the second session of the Thirty-eighth Congress convened in December 1864, it took up a constitutional amendment abolishing slavery. After some pulling and hauling both Houses mustered the two-thirds majority needed to approve what became the Thirteenth Amendment. ${ }^{78}$ For reasons that have never been entirely clear, the amendment was presented to the President pursuant to Article I, Section 7, of the Constitution, and signed. ${ }^{79}$ Ratifications began to pour in.

75 See Abraham Lincoln, Proclamation, July 8, 1864, in Richardson, ed, 6 Messages and Papers of the Presidents at 222-23 (cited in note 14) (explaining pocket veto of Wade-Davis bill).

76 Id at 223.

77 Id. To be more exact, Lincoln was prepared to appoint military governors who would administer the Wade-Davis terms as soon as military resistance had been suppressed and the people had returned to their obedience to the Constitution and laws of the United States. Id.

78 See Herman Belz, A New Birth of Freedom: The Republican Party and Freedmen's Rights, 1861-1866 114 (Greenwood 1976) (noting difficulty in passing the amendment and its passage on January 31,1865 ). Drafting the amendment was not as straightforward a matter as one may think. See id at 113-34 (recounting debates). As Belz explains, associated with the abolition of slavery was the question of the status of freed slaves, and in particular the question whether emancipation automatically conferred on them civil or even political rights. Id at 11634. Belz maintains that the drafters deliberately drew on the language of the Northwest Ordinance because that language, as applied in the states created under it, was understood as providing mere liberty and no particular set of civil or political rights. Id at 114-15, 125-26.

79 See Francis Newton Thorpe, 3 The Constitutional History of the United States, 1765-1895: 1861-1895 154 (Callaghan 1901) (noting that Lincoln followed the normal process for approval of legislation). Article I, Section 7, requires that every bill, vote, resolution, or order "to which the Concurrence of the Senate and House of Representatives may be necessary (except on a question of Adjournment) shall be presented to the President of the United States" for signature or veto. US Const Art I, $\S 7, \mathrm{cl} 3$. Whether it applies to constitutional amendments is a longstanding puzzle. With the exception of the Thirteenth, amendments proposed by Congress have not been submitted to the President, evidently on the theory that they are a special case not covered by Section 7 . The issue was raised in the 1790 s with respect to the Eleventh Amendment. In Hollingsworth $v$ Virginia, 3 US ( 3 Dall) 378 (1798), the Court ruled against the party objecting to the amendment (part of the objection was that the President had not signed the amendment), but the extremely brief account in Dallas's report gives no explanation for the holding. See id at 381. In 1865 , Senator Trumbull quickly moved to scotch any precedential effect of the submission of the Thirteenth Amendment to Lincoln, introducing a resolution stating that the President's signature was not required. See Cong Globe, 38th Cong, 2d Sess 588, 629-31 (Feb 4, 1865) (resolution and amendment); Thorpe, 3 Constitutional History at 154.

80 See Thorpe, 3 Constitutional History at $157 \& \mathrm{nn} 2-4$ (cited in note 79) (providing chronology of rapid ratifications). 


\section{Theories of reconstruction.}

Those ratifications raised some tricky questions. Four of them came from organizations purporting to be the legislatures of Virginia, Louisiana, Tennessee, and Arkansas. ${ }^{81}$ What about them? How many states were there, how many of them had legally valid legislatures, and if there were fewer legislatures than states, did Article $V$ require ratification by three-fourths of the states or three-fourths of the legally valid state legislatures? In response to these and related questions concerning the legal capacities of the states, Americans produced many theories of reconstruction. From the mountain of words devoted to this subject during the 1860 s, I think it is possible to extract a few gold nuggets identifying the leading positions taken by participants in the debate. ${ }^{82}$

All theories of what had happened since 1860 addressed this basic question: what was the legal effect of the ordinances of secession and the acts the southerners had taken to make them stick? At one end of the spectrum was Thaddeus Stevens, who maintained that the southern states had left the Union and been conquered by the United States. Under this "conquered provinces" theory, the states as political entities no longer existed and their inhabitants had the legal status of alien enemies, which meant that their property was subject to expropriation by the conqueror. ${ }^{83}$ Almost as radical was the theory that secession had destroyed the states as such, without removing their territory or people from the jurisdiction of the United States. Propounded

81 By mid-April 1865, twenty-one legislatures had ratified if one counts Virginia (February 9), Louisiana (February 17), Tennessee (April 7), and Arkansas (April 14). 1 USC LXII. (The Virginia legislature was the one sitting in Alexandria. See Randall, Constitutional Problems at 397, 461 (cited in note 21).) The other seventeen states were Illinois, Rhode Island, Michigan, Maryland, New York, Pennsylvania, West Virginia, Missouri, Maine, Kansas, Massachusetts, Ohio, Indiana, Nevada, Minnesota, Wisconsin, and Vermont. See 1 USC LXII. Connecticut ratified on May 4,1865, and New Hampshire on July 1, see id, bringing the total to twenty-three or nineteen, depending on how one counts.

82 This of course requires suppressing many complexities, not the least of which involves the inconsistency through time of individuals.

The classic treatment, which I think has largely stood the test of time but requires some modification, is Dunning's. William Archibald Dunning, Essays on the Civil War and Reconstruction and Related Topics 100-12 (Peter Smith 1931) (explaining five major classes of theories of Reconstruction: the southern theory, the presidential theory, the theory of forfeited rights, the theory of state suicide, and the conquered provinces theory). Torrents have passed under the historiographic bridge since Dunning wrote, but his work on this topic is largely unaffected. (Theories relating specifically to Article V will receive separate treatment in Part I.B below.)

83 See, for example, Cong Globe, 39th Cong, 2d Sess 251-53 (Jan 3, 1867) (remarks of Rep Stevens); Cong Globe, 40th Cong, 1st Sess 545-46 (July 9, 1867) (same). In Stevens's view, Reconstruction and similar measures taken during the war were taken outside of the Constitution. Examples included the admission of West Virginia and military reconstruction. Cong Globe, 40th Cong, 2d Sess 2214 (Mar 28, 1868) (remarks of Rep Stevens, citing these examples). See also Dunning, Essays on the Civil War at 107-09 (cited in note 82) (discussing Stevens's conquered province theory). 
by Charles Sumner early in the war, this "territorial status" thesis implied that Congress could rule the former states with its Article IV power over territories, and could admit new states from that territory if, when, and in the form it chose.

Although those theories had attractions for those who controlled the national government, they laid the Republicans open to charges of gross hypocrisy. Early in the war, both Houses of Congress had endorsed resolutions explaining that the war was not one of conquest or subjugation, but was to preserve the Union and the Constitution, with all the rights of the states and the national government intact. ${ }^{\text {ss }}$

Much more popular among Republicans was the theory first propounded by Representative Samuel Shellabarger of Ohio in January 1866 and subsequently refined until it achieved the status of boilerplate. ${ }^{86}$ According to Shellabarger, secession did not take the states out of the Union; there was still a State of South Carolina with the same territory and largely the same population it had in October 1860. But something legally significant did happen when the people of the seceded states replaced their loyal governments with governments attached to the Confederacy: they destroyed their earlier governments, those that had maintained political relations with the other states and

84 See Cong Globe, 37th Cong, 2d Sess 736-37 (Feb 11, 1862) (Sumner's resolutions). See also Dunning, Essays on the Civil War at 105-07 (cited in note 82) (discussing Sumner's thesis). This approach was also called the "state suicide" theory. Id.

85 McPherson, Rebellion at 286 (cited in note 18) (resolutions of July 22, 1861 (House) and July 25,1861 (Senate)).

86 See Cong Globe, 39th Cong, 1st Sess 142-45 (Jan 8, 1866) (remarks of Rep Shellabarger). He began by rejecting the thesis that "any territory passed from under" the jurisdiction of the United States, as well as the claim that any state "lost its territorial character or defined boundaries." Id at 142. As far as he was concerned, both the conquered provinces and territorial status theories were off the table. Rather, the question was whether it was

under our Constitution possible to, and the late rebellion did in fact so, overthrow and usurp in the insurrectionary States the loyal State governments as that, during such usurpation, such States and their people ceased to have any of the rights or powers of government as States of this Union; and this loss of the rights and powers of government was such that the United States may and ought to assume and exercise local powers of the lost State governments, and may control the readmission of such States to their powers of government in this Union, subject to and in accordance with the obligation to "guaranty to each State a republican form of government."

Id. James G. Blaine of Maine, then a representative, later Speaker of the House, and in 1884 the Republican candidate for President, later described the influence Shellabarger's speech had on members of his party. "Other speeches have gained greater celebrity, but it may well be doubted whether any speech in the House of Representatives ever made a more enduring impression, or exerted greater convincing power, upon the minds of those to whom it was addressed." James G. Blaine, 2 Twenty Years of Congress: From Lincoln to Garfield 135 (Henry Bill 1886) (recounting debates over theories of Reconstruction). According to McKitrick, "Shellabarger's theory ultimately became, in one form or another, the majority position on reconstruction." Eric L. McKitrick, Andrew Johnson and Reconstruction 113 (Chicago 1960) (explaining and evaluating theories). 
the national government. ${ }^{87}$ It was as if the people of South Carolina, assembled in convention, had abrogated all the laws that established and empowered the South Carolina government, and then gone home to think about what to do next.

War Democrats, typified by Andrew Johnson, seem generally to have believed that secession and the creation of Confederate state governments had suspended the operation of the states' political laws without abrogating them. ${ }^{89}$ Like the Republicans, Johnson was unwill-

87 Shellabarger argued that of course the Confederate state governments had no right to participate in the United States government and then rejected the possibility that during the course of the rebellion the states' political powers were simply in "suspended animation." Cong Globe, 39th Cong, 1st Sess 143 (Jan 8, 1866). Rather, the "old State governments were so effectually overthrown that they do not come into force at the end of the war so as to furnish the basis of republican governments to these States." Id at 143-44. Almost two years later, by which time the theory had become routine Republican doctrine, Senator Lot Morrill of Maine repeated the argument: by rejecting the Article VI oath, the ligament that binds states to the Union, the people of the states destroyed their state governments. Cong Globe, 40th Cong, 2d Sess Appendix 111-12 (Feb 5, 1868).

88 Dunning seems to have had in mind Shellabarger's thesis when he referred to the theory that the southern states had forfeited their rights in the national government without eliminating themselves as states. Dunning, Essays on the Civil War at 109-11 (cited in note 82). Although that is not a bad way of putting the point, it can easily lead one to slip into the less plausible theory that the states as such had committed a crime and the forfeiture worked as a punishment. That is one reason to refer to Shellabarger's idea as the theory of destroyed governments; that reminds us that the reason the states no longer had their federal rights was not a crime but a political act of their people.

From early 1866 on, Republicans routinely referred and alluded to the destroyed governments thesis. See, for example, Cong Globe, 39th Cong, 2d Sess 159-60 (Dec 17, 1866) (Sen Trumbull); id at 1082 (Feb 7, 1867) (Rep Bingham); Cong Globe, 40th Cong, 2d Sess 4140-44 (July 16, 1868) (Rep Van Horn).

At least one Republican took this position to the extreme, arguing that the southerners had abolished all their laws, not just their political laws, and were living in a state of nature. Cong Globe, 39th Cong, 2d Sess 559-60 (Jan 18, 1867) (Rep Donnelly).

One Democrat, Senator Saulsbury of Delaware, got off a good line in response to the theory:

It is said that though it is true that Virginia, North Carolina, South Carolina, and Georgia had State governments prior to the late war; somehow or other, during the continuance of the war, they lost those State governments, have not been able to find them, and must appeal to Congress to set up State governments for them.

Id at 1448 (Feb 16, 1867) (Sen Saulsbury).

The destroyed governments thesis was also the preferred theory of the leading Republican journal of opinion, The Nation, which endorsed the idea as early as April 1866 and drew what would become the standard Republican conclusion, that acting under the Guarantee Clause Congress could provide for the creation of new state governments based on race-blind suffrage. 2 Nation 518 (Apr 26, 1866). The Nation at the same time rejected Stevens's conquered provinces theory, claiming that it was "almost as unpalatable to the conquerors as to the conquered," and that even those who believed in it as a legal theory were unwilling to act on it. Id. See also $4 \mathrm{Na}$. tion 10 (Jan 3, 1867) (reiterating destroyed governments theory); 4 Nation 61 (Jan 23, 1868) (same).

89 In his first State of the Union message, Johnson explained that the "States attempting to secede placed themselves in a condition where their vitality was impaired, but not extinguished; their functions suspended, but not destroyed." Andrew Johnson, First Annual Message, Dec 4, 1865, in Richardson, ed, 6 Messages and Papers of the Presidents at 357 (cited in note 14). 
ing to accept the possibility that the organization headquartered in Columbia, South Carolina, during the war was the government of the State of South Carolina. By definition, they all agreed, the government of a state is one attached to the Union and the Constitution, so an organization that is not so attached is not the government of a state. One could tell a Confederate State from a United State by finding out which oath its officers are required to take. Hence there was no United State government of South Carolina during the war. It was as if all the state's officers had resigned or perished in a plague.

\section{When the war was over.}

As the Confederate armies surrendered in the spring of 1865 , a few of the Confederate state governments sought to come back into the Union more or less intact. Presidents Lincoln and then Johnson quickly put paid to that idea, dispersing the rebel regimes and leaving seven states with no functioning state government. ${ }^{92}$ Johnson had his own plans for restoration, and those plans involved neither the Confederate authorities nor a special session of Congress. In his view the former Confederate States fell into two categories: those that already had loyal state governments and those that needed a little help in establishing one. Johnson's thinking about the first group came out in

90 The terminology I adopt, under which Francis Pierpont was Governor of the United State of Virginia while John Letcher was Governor of the Confederate State of Virginia, places some strain on the reader by requiring careful attention to the absence or presence of the letter "s". It seems the most natural nomenclature, however, and I hope it is worth the trouble.

91 Representative Andrew Jackson Rogers of New Jersey, who was as Democratic as his name, was another subscriber to the theory that during the war the southern states remained in the Union but had no valid government for purposes of their federal relations. Cong Globe, 39 th Cong, 2d Sess Appendix 84-85 (Feb 7, 1867).

92 The seven states were North Carolina, South Carolina, Georgia, Florida, Alabama, Mississippi, and Texas. See notes 96-100 and accompanying text. After some to-ing and fro-ing as to whether the Confederate Virginia legislature would be allowed to meet in order to take Virginia out of the war, Lincoln suppressed the Confederate State government of Virginia. Ambler, Pierpont at 254-60 (cited in note 17). Explaining his communications with those rebels, Lincoln pointed out that in suggesting a possible meeting he had referred to "the gentlemen who had acted as the Legislature of Virginia" specifically "on purpose to exclude the assumption that I was recognizing them as a rightful body." Abraham Lincoln, telegram to Major General Weitzel, Apr 12,1865, in Edward McPherson, The Political History of the United States of America During the Period of Reconstruction 26 (Philp \& Solomons 1871) (internal quotations omitted).

President Johnson repudiated a surrender agreement in which General Sherman suggested that North Carolina's rebel legislature could return to loyalty by taking the Article VI oath. See W.T. Sherman and J.E. Johnston, memorandum, Apr 18, 1865, in McPherson, Reconstruction at 121-22 (agreement); Edwin M. Stanton, dispatch, Apr 22, 1865, in McPherson, Reconstruction at 122 (Johnson's disapproval). In May 1865, when the Confederate Governor of Mississippi sought to call the legislature so that it could summon a reconstruction convention, President Johnson ordered the military to "prevent, by force if necessary, any attempt of any of the legislatures of the States in insurrection to assemble for legislative purposes, and [to] imprison any members or other persons who may attempt to exercise these functions in opposition to your orders." E.R.S. Canby, telegram, May 21, 1865, in McPherson, Reconstruction at 19. 
his Executive Order of May 9, 1865, respecting Virginia. Most of the order was concerned with the reestablishment of federal civil authority. ${ }^{93}$ Having dealt with the ordinary operations of the federal government within a state, Johnson's order turned to the state government of Virginia. Johnson's position was clear. Francis Pierpont was Governor. Johnson did not purport to appoint Pierpont to office; rather, he stated that as far as the federal executive was concerned, Pierpont was the Governor and would be given the assistance to which a Governor was entitled."

Seven seceded states had neither a spontaneously formed loyalist government like Pierpont's nor a government formed in response to Lincoln's invitation of December $1863 .^{\circ 6}$ Johnson made known his proposal for restoring them to their former status in two proclama-

93 See Andrew Johnson, Executive Order, May 9, 1865, in Richardson, ed, 6 Messages and Papers of the Presidents at 337-38 (cited in note 14) (directing various cabinet officers to reestablish control over Virginia). The order also swept aside the claim of the Confederate Virginia government to continue. Its Governors had been John Letcher and William Smith; Johnson put them in bad company.

All persons who shall exercise, claim, pretend, or attempt to exercise any political, military, or civil power, authority, jurisdiction, or right by, through, or under Jefferson Davis, late of the city of Richmond, and his confederates, or under John Letcher or William Smith and their confederates, or under any pretended political, military, or civil commission or authority issued by them or either of them since the 17th day of April, 1861, shall be deemed and taken as in rebellion against the United States, and shall be dealt with accordingly.

Id at 337.

94 Johnson proclaimed

[t]hat to carry into effect the guaranty by the Federal Constitution of a republican form of State government and afford the advantage and security of domestic laws, as well as to complete the reestablishment of the authority and laws of the United States and the full and complete restoration of peace within the limits aforesaid, Francis H. Peirpont, governor of the State of Virginia, will be aided by the Federal Government so far as may be necessary in the lawful measures which he may take for the extension and administration of the State government throughout the geographical limits of said State.

Id at 338.

95 Id. Pierpont arrived in Richmond from Alexandria on May 26, 1865, in a captured blockade runner provided by the Navy. Ambler, Pierpont at 262-63 (cited in note 17). Once he and his administration were in place, they set about turning their rump into a genuine government of Virginia. As far as Pierpont was concerned, Virginia was already a free state, because a constitutional convention meeting at Alexandria in 1864 had adopted a new constitution that abolished slavery. See Va Const of 1864 Art IV, $\$ \S 19-21$ (superseded 1870) (prohibiting slavery and involuntary servitude). The 1864 document provided for adult white male suffrage, subject to a test oath that excluded those who had voluntarily served the Confederacy after January 1 , 1864. Id Art III, § 1. The legislature was empowered to provide for the restoration of the franchise to the disqualified. Id. Pierpont called a special session of the Alexandria legislature in June 1865 , which removed the disqualification and provided for fall elections for the state legislature and Congress. See Ambler, Pierpont at 274. See also 1865 Va Acts ch vi (extra session of June 19) (removing disqualifications); id ch viii (providing for elections).

96 They were North Carolina, South Carolina, Georgia, Florida, Alabama, Mississippi, and Texas. See text accompanying notes 98-100 (noting that President Johnson authorized provisional governors for these states). 
tions of May 29, 1865. The first offered a pardon to most former rebels, provided they would take an oath to support the Constitution and emancipation. ${ }^{97}$ The second set in motion a plan to reconstruct North Carolina, a plan that was then used as a blueprint for the other six states.

Johnson began with the appointment of a provisional Governor, William Holden, for North Carolina. Holden was then authorized to convene a convention to be chosen by the loyal people of North Carolina, a convention

for the purpose of altering or amending the constitution thereof, and with authority to exercise within the limits of said State all the powers necessary and proper to enable such loyal people of the State of North Carolina to restore said State to its constitutional relations to the Federal Government and to present such a republican form of State government as will entitle the State to the guaranty of the United States therefor and its people to protection by the United States against invasion, insurrection, and domestic violence.

Then came the kicker: the President decided who was loyal, prescribing suffrage qualifications for electing the convention."

In due course similar proclamations were issued for Mississippi on June 13, Georgia and Texas on June 17, Alabama on June 21, South Carolina on June 30 , and finally Florida on July $13 .^{100}$ Pursuant to Johnson's proclamations, the provisional governors organized elec-

97 To qualify, a former rebel had to swear or affirm "that I will henceforth faithfully support, protect, and defend the Constitution of the United States and the Union of the States thereunder, and that I will in like manner abide by and faithfully support all laws and proclamations which have been made during the existing rebellion with reference to the emancipation of slaves." Andrew Johnson, Proclamation, May 29, 1865, in Richardson, ed, 6 Messages and Papers of the Presidents at 310-11 (cited in note 14).

Not all ex-Confederates were entitled to the blanket pardon Johnson offered. His proclamation excluded various categories of Confederate leaders, such as those who had specially offended the United States by, for example, raiding Union commerce, and owners of more than $\$ 20,000$ worth of property who voluntarily aided the rebellion. Id at $311-12$. Former rebels excluded from the offer had to apply for personal pardons. Id at 312.

$98 \quad$ Id at 313.

99 The Proclamation included the following provision:

[I]n any election that may be hereafter held for choosing delegates to any State convention as aforesaid no person shall be qualified as an elector or shall be eligible as a member of such convention unless he shall have previously taken and subscribed the oath of amnesty as set forth in the President's proclamation of May 29, A.D. 1865, and is a voter qualified as prescribed by the constitution and laws of the State of North Carolina in force immediately before the 20th day of May, A.D. 1861, the date of the so-called ordinance of secession.

Id at 313 .

100 Id at 314-16 (Mississippi); id at 318-20 (Georgia); id at 321-23 (Texas); id at 323-25 (Alabama); id at 326-28 (South Carolina); id at 329-31 (Florida). 
tions for conventions. Six met in 1865, while Texas's convention did not organize until March $1866 .{ }^{101}$ Three leading issues came before the conventions: secession itself, the abolition of slavery, and the Confederate war debt.

The six conventions that met in 1865 complied with what they perceived as northern demands with varying degrees of contumacy. ${ }^{102}$ All rejected secession, although not necessarily in terms calculated to please Union sentiment. ${ }^{103}$ All legislated against slavery in one way or another, although once again not always with much grace. ${ }^{104}$ All but Mississippi's and South Carolina's repudiated the rebel war debt. ${ }^{105}$ Only North Carolina's convention submitted any of its actions to the people for ratification; North Carolina voters approved the repudiation of secession and the abolition of slavery. ${ }^{106}$

During their deliberations the conventions received some guidance from the Executive in Washington. Mississippi's was the first to meet, and as it was organizing the President telegraphed Provisional Governor Sharkey expressing his hope that the convention would abolish slavery and ratify the Thirteenth Amendment. ${ }^{107}$ Next was Alabama, where the convention promptly complied with everything it thought the President wanted. ${ }^{108}$ South Carolina turned out to be a little tone deaf, repealing rather than declaring null its ordinance of secession and doing nothing about the rebel debt. ${ }^{109}$ North Carolina's

101 See McPherson, Reconstruction at 18-28 (cited in note 92) (giving chronological accounts of actions of the various conventions and legislatures). Mississippi's convention assembled on August 14, Alabama's on September 12, South Carolina's on September 13, North Carolina's on October 2, Florida's and Georgia's on October 25. Id.

102 See John W. Burgess, Reconstruction and the Constitution, 1866-1876 38-39 (Scribner's 1911) (summarizing state responses); McPherson, Reconstruction at 18-28 (cited in note 92) (same).

103 South Carolina's convention, for example, repealed its predecessor's ordinance of secession as if it had been valid. McPherson, Reconstruction at 22 (cited in note 92). North Carolina's was more conciliatory, declaring the ordinance "null and void." Id at 18.

104 See id at 18-28 (describing the actions of the conventions and legislatures with respect to slavery). Georgia's convention, for example, explained that slavery was abolished because the Government of the United States had freed the slaves as a war measure and had carried that plan into effect. Id at 20.

105 Id at $18-28$.

106 Poore, ed, 2 The Federal and State Constitutions at 1419 (cited in note 64) (reprinting ordinance); McPherson, Reconstruction at 19 (cited in note 92) (listing November 9 as date of popular approval of ordinances).

107 McKitrick, Andrew Johnson at 166 (cited in note 86).

108 Id at $166-67$.

109 Id at 167 (discussing the obstinate attitude of the South Carolina convention and provisional governor). One should judge the South Carolina convention's action by appropriate local standards. In his penetrating study of self-reconstruction and the first-round governments, Dan Carter explains that the conventions were not mainly composed of ardent secessionists:

Overwhelmingly, southern voters chose cautious and conservative post-war leaders who had opposed secession until the movement for southern independence was an accomplished fact. The clearest evidence of this predilection for antebellum southern unionists 
convention met shortly after South Carolina's, and when it showed signs of wavering on the repudiation question, President Johnson cabled Provisional Governor Holden that "[e]very dollar" of the rebel debt "should be repudiated finally and forever," and it was." Georgia's convention also balked on the Confederate war debt and was given some candid advice about the President's views: Secretary Seward cabled Provisional Governor Johnson that the President "cannot recognize the people of any State as having resumed the relations of loyalty to the Union that admits as legal, obligations contracted or debts created in their name, to promote the war of the rebellion." That did the trick. ${ }^{1.2}$ Sixth and last in 1865 , Florida's convention did all that was called for."

In addition to modifying their state constitutions, the conventions needed to get their ordinary governments going again. That meant elections for state offices and representatives in Congress. By the end of November all six Johnson states that held conventions in $1865 \mathrm{had}$ also conducted those elections. ${ }^{114}$ When the new legislatures met, high on their agenda was the proposed constitutional amendment. Five ratified, beginning with South Carolina on, November $13 .^{1.15}$ South Carolina acted in the shadow of an exchange of telegrams between Provisional Governor Perry and the Executive in which Secretary Seward had stated that the President regarded ratification as "indispensable to a restoration of [South Carolina's] relations with the other States of the Union." 116 Alabama ratified on December 2, North Caro-

can be seen in the background of those 1865 convention delegates who had also served in their state's secession convention.

Dan T. Carter, When the War Was Over: The Failure of Self-Reconstruction in the South, 1865186765 (LSU 1985). Carter discusses the moderates from North Carolina, Mississippi, and Georgia and then comes to the Palmetto State. Id. "Even in South Carolina, where secession had been the overwhelming choice of the people, fifteen of the twenty postwar delegates who had served in the 1860 secession convention had opposed their state's separation from the Union until after Lincoln's election. By South Carolina standards, this was unionism." Id.

110 McKitrick, Andrew Johnson at 168 (cited in note 86).

111 McPherson, Reconstruction at 21 (cited in note 92) (providing chronology of actions of the Georgia convention).

112 McKitrick, Andrew Johnson at 168 (cited in note 86).

113 McPherson, Reconstruction at 24 (cited in note 92) (providing chronology of actions of the Florida convention); McKitrick, Andrew Johnson at 168 (cited in note 86) (noting that at the Florida convention "everything went off without a hitch"). Despite Johnson's interventions, McKitrick concludes that "[a]ll had been, in the last analysis, voluntary." Id (Florida was last in 1865 because Texas's convention did not meet until 1866.).

114 McPherson, Reconstruction at 18-28 (cited in note 92) (giving chronologies of the actions of the conventions and legislatures of the former Confederate States).

115 Id at 23.

116 William H. Seward, telegram to Provisional Governor B.F. Perry, Nov 6, 1865, in McPherson, Reconstruction at 23 (cited in note 92). Apparently the South Carolinians still did not quite get it; their resolution of ratification included a clause stating that the amendment gave Congress no power to legislate as to the civil or political rights of the freed slaves. Id. 
lina on December 4, Georgia on December 6, and Florida on December 28. ${ }^{117}$ Mississippi's legislature did not ratify. ${ }^{118}$

Secretary Seward had not only been sending telegrams, he had been counting. He counted thirty-six states in all, thus rejecting the possibility that any had left the Union or been destroyed. With Georgia's action on December 6, he counted twenty-seven ratifications. So on December 18, 1865, in keeping with a duty imposed on the Secretary of State by a statute from 1818 , he issued a certificate stating that Congress had proposed a constitutional amendment by the requisite two-thirds vote, that twenty-seven states had ratified, that the whole number of states in the Union was thirty-six, that twenty-seven was the requisite three-fourths majority, and that the amendment had "be[come] valid, to all intents and purposes, as a part of the Constitution of the United States."

While the southern state legislatures were engaged in this process, the national legislators were preparing for the session that would open on December 4,1865 , the first meeting of the full Congress after nine eventful months. ${ }^{120}$ Senators- and representatives-elect would present themselves from almost all the southern states, and the great question was whether they would be seated. ${ }^{121}$ Before Congress opened, the Republican leadership of House and Senate concerted a procedure to deal with the southern claimants. ${ }^{122}$ A Joint Committee

1171 USC LXII. Alabama and Florida joined South Carolina in expressing a limited view of congressional power over the status of the freed people. See McPherson, Reconstruction at 21 (cited in note 92) (Alabama denied congressional power to legislate on the political status of freedmen.); id at 24-25 (Florida did the same.). Secretary Seward had advised the Provisional Governor of Florida that the President regarded ratification as indispensable to Florida's restoration to her true legal relations with the other states. Id at 25 (reproducing correspondence).

118 Id at 20.

119 William H. Seward, Certificate of the Anti-Slavery Amendment, known as the 13th Amendment, Dec 18,1865, in McPherson, Reconstruction at 6 (cited in note 92). Although the latest state on Seward's list was Georgia, which ratified on December 6, by the date of his proclamation Oregon had also ratified. California ratified on December 19, Florida did so on December 28 , Iowa on January 15,1866 , and New Jersey (where the legislature had voted down ratification on March 16,1865) on January 23, 1866. Texas, where reconstruction was an even dicier affair than elsewhere, ratified on February 18, 1870. See 1 USC LXII (listing ratifications).

120 See Cong Globe, 39th Cong, 1st Sess 1 (Dec 4,1865) (opening the session).

121 The personal histories of the southern claimants varied widely. At one end of the spectrum was Representative-elect Horace Maynard of Tennessee, an impeccable unionist who had sat in the Thirty-fifth, Thirty-sixth, and Thirty-seventh Congresses. See Dumas Malone, ed, 12 Dictionary of American Biography 460-61 (Scribner's 1933) (reviewing Maynard's political career). At the other end was a senator-elect from Georgia: Alexander H. Stephens, last heard from as Vice President of the Confederate States of America. See McPherson, Reconstruction at 10709 (cited in note 92) (listing the southern claimants and the Confederate credentials of those who had them).

122 Kendrick gave an account of the plan's genesis that made it seem a Machiavellian stroke put over on unsuspecting conservative Republicans by the arch-manipulator, Thaddeus Stevens. See Benj. B. Kendrick, The Journal of the Joint Committee of Fifteen on Reconstruction: 39th Congress, 1865-1867 139-41 (Columbia 1914). McKitrick is less impressed by the conspiracy the- 
on Reconstruction would be formed, and all credentials presented by senators- and representatives-elect from the seceded states would be referred to it without further debate. ${ }^{123}$ House and Senate agreed to act jointly; no southerner would be seated by either body until the Joint Committee had reported and its report had been acted on.

This decision led to a memorable scene when the House of Representatives convened on December 4. Edward McPherson, Clerk of the House for the Thirty-eighth Congress, began to read the roll, omitting representatives-elect from the southern states. ${ }^{125}$ When McPherson came to the letter "M" and did not call Horace Maynard of Tennessee, Maynard rose and demanded to know whether the Clerk would call his name. ${ }^{126}$ McPherson responded that he could not recognize anyone whose name was not on the roll (which he had made himself), and Representative-elect James Brooks, a prominent Democrat from New York, objected vigorously lest the House proceed on any "revolutionary step." ${ }^{127}$ But the roll call continued without the southerners, and Schuyler Colfax of Indiana was elected Speaker. ${ }^{128}$ Shortly after Colfax's acceptance speech, Stevens offered a joint resolution creating the

ory, arguing that something like creation of the Joint Committee was a routine decision that could just as easily have been proposed by almost any Republican representative as by Stevens. See McKitrick, Andrew Johnson at 259 (cited in note 86).

The Republicans were able to make their plans with confidence because of a crucial political fact: their party held an absolute majority of both houses of Congress, even if all the states were counted. See Congressional Quarterly's Guide to Congress Appendix 94-A (Cong Q 4th ed 1991) (giving political party affiliations in Congress, 1789-1991). It was therefore impossible for the northern Democrats to combine with the southerners and claim to organize the House or Senate, because they would have been unable to muster a quorum. See US Const Art I, \& 5, cl 1 ("a Majority of each [house] shall constitute a Quorum to do Business").

123 See McKitrick, Andrew Johnson at 258-59 (cited in note 86) (reproducing part of a joint resolution introduced by $R$ ep Stevens to establish the committee).

124 See Cong Globe, 39th Cong, 1st Sess 6 (Dec 4, 1865) (approval of the resolution).

125 By its own tradition the House of Representatives is not continuous; every two years it is created anew, like the phoenix rising from its ashes. A more apt metaphor in this context would be that at the beginning of every congressional term the House is reduced to a state of nature. It has no rules, no Speaker, and indeed no fixed membership, because the elections, qualifications, and returns of its members are to be decided by the House itself. In order to bootstrap the House into existence at its first sitting of every term, the federal statutes have long provided that at the time set for the beginning of the first session of every term the Clerk of the House of Representatives from the prior term is to call the roll of those who have presented credentials as representatives-elect. See Act of March 3, 1863, ch CVIII, 12 Stat 804.

126 Cong Globe, 39th Cong, 1st Sess 3 (Dec 4, 1865).

127 Id.

128 Id at 5 . No such theatrics took place in the Senate, which by tradition considers itself a continuous body. Moreover, the first meeting of the Senate of the Thirty-ninth Congress had taken place already, in the special session in March 1865 that sat to confirm President Lincoln's new nominees. See Cong Globe, 38th Cong, 2d Sess 1424-25 (Mar 4, 1865) (convening of a special session of the Senate). So the Senate already had a fixed membership and a presiding officer, and could meet and consider the credentials of new senators-elect. See Cong Globe, 39th Cong, 1st Sess 1-3 (Dec 4, 1865) (meeting of Senate). 
Joint Committee, which was promptly passed without debate under a suspension of the rules. ${ }^{129}$

Shortly after this excitement the House turned to the reading of President Johnson's first State of the Union message, the opening line of which might have been mere rhetoric under any other circumstances: "To express gratitude to God in the name of the people for the preservation of the United States is my first duty in addressing you." ${ }^{130}$ Johnson went on to set out his theory of a Union and states alike indissoluble, and to explain what he had done in the preceding months. ${ }^{131}$ He had found the seceded states "in a condition where their vitality was impaired, but not extinguished; their functions suspended, but not destroyed." In response, he had put the federal government's machinery largely back into operation and through his provisional governors helped the states put themselves back into operation. ${ }^{133}$ After describing how much the abolition amendment would help the country, he indicated that Congress could do its part to encourage the healing of the rift of slavery:

The amendment to the Constitution being adopted, it would remain for the States whose powers have been so long in abeyance to resume their places in the two branches of the National Legislature, and thereby complete the work of restoration. Here it is for you, fellow-citizens of the Senate, and for you, fellow-citizens of the House of Representatives, to judge, each of you for yourselves, of the elections, returns, and qualifications of your own members. $^{1.34}$

Their judgment was that they were going to think about it, and the first session of the Thirty-ninth Congress had a lot to think about. Probably the most important issue for practical purposes was a classic example of the principle of unintended consequences. By freeing the slaves, the Union had made the South politically more powerful. As free people the former slaves would count as whole persons for appor-

129 Cong Globe, 39th Cong, 1st Sess 6 (Dec 4, 1865). As Kendrick pointed out, the resolution as Stevens formulated it seemed almost calculated to offend the President; joint resolutions are legislative actions under Article I, $\S 7$, and as such are presented to the President for signature or veto. Kendrick, Journal of the Joint Committee at 143-44 (cited in note 122). The Senate's version was a concurrent resolution, the kind of action that governs internal congressional affairs and is not presented to the President, and that is the version in which it eventually passed both Houses. See id (noting that it was fortunate that the Senate, unlike the House, passed the resolution in concurrent, rather than joint form, because this avoided offending the President).

130 Andrew Johnson, First Annual Message, Dec 4, 1865, in Richardson, ed, 6 Messages and Papers of the Presidents at 353 (cited in note 14).

131 Id at 353-58.

132 Id at 357.

133 Id.

134 Id at 358. 
tionment, not as three-fifths. ${ }^{135}$ They remained disenfranchised, however, so rather than having a voice of their own they amplified that of their former masters. If nothing were done about this, the Constitution would substantially increase the power in the federal government of southern whites, most of whom the Republicans regarded as traitors. ${ }^{136}$

What to do about the political rights of those traitors was another question. So was the legal status of the freed slaves, which the new southern legislatures often treated harshly. Those legislatures passed the infamous Black Codes, adopted in 1865 and 1866. Provisions that, for example, limited the capacity of blacks to own real property and to testify in court infuriated Republicans. ${ }^{137}$

The intricate workings of Congress on these issues in the winter and spring of 1865 to 1866 has been gone over many times and a detailed account is not necessary here..$^{138}$ The important point is that the Joint Committee on Reconstruction, after a few false starts, produced a proposed constitutional amendment, a report setting out its theory of reconstruction, and a bill that linked the two. The amendment, which with two alterations became the Fourteenth, sought a comprehensive solution to the problems the Republicans thought the country faced. ${ }^{139}$

\section{The Constitution mandates:}

Representatives and direct Taxes shall be apportioned among the several States which may be included within this Union, according to their respective Numbers, which shall be determined by adding to the whole Number of free Persons, including those bound to Service for a Term of Years, and excluding Indians not taxed, three fifths of all other Persons.

US Const Art I, $\S 2$, cl 3. This affected not only the House, but also the Electoral College, because every state has as many electors as it has senators and representatives combined. See id Art II, $\S$ $1, \mathrm{cl} 2$.

136 Eric Foner, Reconstruction: America's Unfinished Revolution, 1863-1877 251-52 (Harper \& Row 1988). Foner describes one Republican parade of horribles, which included the election of Robert E. Lee as President in 1868. Id at 252.

137 Fairman summarizes the timing and content of the Codes. Charles Fairman, 6 History of the Supreme Court of the United States: Reconstruction and Reunion, 1864-88, Part One 110-15 (Macmillan 1971). McPherson provided extensive excerpts from every state's legislation. McPherson, Reconstruction at 29-44 (cited in note 92). Carter offers an insightful account of the social and political factors that led to the Codes. Carter, When the War Was Over at 176-231 (cited in note 109). As to the political disaster for the South that resulted from the Codes and similar behavior, Carter points out that "[b]y January of 1866, Republican notions of southern perfidy and political unreliability were firmly established." Id at 232.

138 For the historian of constitutional law, the most useful contemporary work is Earl M. Maltz, Civil Rights, the Constitution, and Congress, 1863-1869 (Kansas 1990). Maltz's account of the maneuverings in drafting the Fourteenth Amendment, id at 79-92, is especially illuminating.

139 Section 1 was aimed at the Black Codes. See McPherson, Reconstruction at 103 (cited in note 92) (reproducing amendment proposed in the House, Apr 30,1866). Section 2 was a clever solution to the problem of the enhanced Slave Power, giving states with large black populations a choice between enfranchising the freed slaves and losing representation in the House and the Electoral College. Id. Section 3 as proposed by the Joint Committee was a fairly harsh disenfranchisement aimed at ex-Confederates. It provided that "[u]ntil the 4th day of July, in the year 1870 , all persons who voluntarily adhered to the late insurrection, giving it aid and comfort, shall 
The report of the Joint Committee's majority maintained that the ex-Confederate States were not entitled to representation and that the amendment represented the terms on which it would be safe to readmit them. It relied heavily on Shellabarger's thinking. Those states, the report argued, had destroyed their former constitutions and were without civil government. ${ }^{100}$ Their recent attempts to establish new constitutions were at best doubtful under established American principles of constitution-making. ${ }^{141}$ Worst of all, the new governments, with the possible exception of Tennessee's, were dominated by traitors and in truth were the rebellion carried on by other means. ${ }^{142}$ And while President Johnson may have concluded that the new governments were lawful and loyal, his view could not bind Congress. ${ }^{143}$ The Committee concluded that the former Confederate States were not entitled to representation and that before they could be readmitted, "adequate security for future peace and safety should be required," security consisting of the Committee's proposed constitutional amendment.

be excluded from the right to vote for representatives in Congress and for electors for President and Vice-President of the United States." Id. As finally proposed by Congress it was substantially milder, forbidding office holding by anyone who had once taken the Article VI oath and then served the Confederacy. See Cong Globe, 39th Cong, 1st Sess 3146 (June 13, 1866) (describing the categories of people precluded from holding certain elected offices). Section 4 dealt with the hot-button issue of the Union and Confederate debts, and Section 5 gave Congress enforcement power. McPherson, Reconstruction at 103.

140 Through rebellion "they destroyed their State constitutions in respect to the vital principle which connected their respective States with the Union and secured their federal relations; and nothing of those constitutions was left of which the United States were bound to take notice." Majority Report of the Joint Committee on Reconstruction, June 18, 1866, in McPherson, Reconstruction at 85 (cited in note 92). Thus the state conventions were wrong if they acted against the background of pre-existing state constitutions; those had been "repudiated and overthrown." Id at 89.

141 "No State constitution, or amendment to a State constitution, has had the sanction of the people. All the so-called legislation of State conventions and legislatures has been had under military dictation." Id at 93 .

142 "The question before Congress is ... whether conquered rebels may change their theatre of operations from the battle-field, where they were defeated and overthrown, to the halls of Congress, and, through their representatives, seize upon the Government which they fought to destroy." Id at 93 . As for whether they were really rebels

[t] he character of the conventions and legislatures thus assembled was not such as to inspire confidence in the good faith of their members... There is no evidence of the loyalty or disloyalty of the members of those conventions and legislatures except the fact of pardons being asked for on their account.

Id at 89. Again, Tennessee may have been different. See, for example, id at 92 ("The State of Tennessee occupies a position distinct from all the other insurrectionary States.").

143 "The powers of conqueror are not so vested in the President that he can fix and regulate the terms of settlement and confer congressional representation on conquered rebels and traitors." Id at 93.

144 Id. 
A minority report by the three Democrats on the Joint Committee claimed that the states were already entitled to representation. A state could neither leave the Union nor, through the crimes of some of its citizens, forfeit its rights under the Constitution. ${ }^{145}$ During the rebellion, the state laws had been suspended in their practical operation, but were revived once the rebellion was suppressed. ${ }^{146}$ The restored state governments were republican in form, and any irregularities in their restoration were no concern of Congress: all that mattered was that the people of the states were satisfied with what had been done in their name. ${ }^{147}$ In particular, it did not matter whether what President Johnson had done was lawful or not, and indeed the argument that he had no business interfering with state constitutional processes applied just as well to Congress as to the President. ${ }^{148}$ What counted was that the states had republican governments that their people accepted. Loyal individuals elected to the Senate and the House under the auspices of those governments were entitled to their seats. ${ }^{149}$

145 Minority Report of the Joint Committee on Reconstruction, June 22, 1866, in McPherson, Reconstruction at 94-95 (cited in note 92). "Tested, therefore, either by the nature of our Government or by the terms of the Constitution, the insurrection, now happily and utterly suppressed, has in no respect changed the relations of the States, where it prevailed, to the General Government." Id at 95.

146 See id at 95-96 (citing decisions of the United States Supreme Court and a United States district court to support this argument).

147 The minority report explained:

It is not pretended that the existing governments of the States in question are not of the required form. The objection is that they were not legally established. But it is confidently submitted that that is a matter with which Congress has nothing to do. The power to establish or modify a State government belongs exclusively to the people of the State. When they shall exercise it, how they shall exercise it, what provisions it shall contain, it is their exclusive right to decide, and when decided, their decision is obligatory upon everybody, and independent of all congressional control, if such government be republican.

Id at 97.

148 The minority report continued:

If it be said that the President did illegally interfere in the organization of such governments, the answers are obvious: First. If it was true, if the people of such States not only have not, but do not, complain of it, but, on the contrary, have pursued his advice, and are satisfied with and are living under the governments they have adopted, and those governments are republican in form, what right has Congress to interfere or deny their legal existence. Second. Conceding, for argument's sake, that the President's alleged interference was unauthorized, does it not, and for the same reason, follow that any like interference by Congress would be equally unauthorized? A different view is not to be maintained because of the difference in the nature of the powers conferred upon Congress and the President, the one being legislative and the other executive; for it is equally, and upon the same ground, beyond the scope of either to form a government for a people of a State once in the Union, or to expel such a State from the Union, or to deny, temporarily or permanently, the rights which belong to a State and her people under the Constitution.

Id.

149 Id (The states must not be denied "the right of having a voice in the legislative department."). 
Along with the report and the amendment was a bill setting out the terms of readmission. Southern states were to ratify the amendment and bring their laws into compliance with it. When the amendment had become part of the Constitution, their senators and representatives would be eligible to be considered on their individual merits. ${ }^{150}$ This proposal was not adopted by the first session of the Thirtyninth Congress. ${ }^{151}$

The Fourteenth Amendment passed Congress on June 13, $1866 .{ }^{1.52}$ One ex-Confederate State promptly accepted the offer. Tennessee, with a Republican legislature, ratified on July $19,1866 .{ }^{153}$ Even more promptly, Congress provided by joint resolution that "Tennessee is hereby restored to her former proper, practical relations to the Union, and is again entitled to be represented by senators and representatives in Congress." ${ }^{\text {"154 }}$ President Johnson, in an early example of a presidential signing statement, gave the legislation his signature, but sent the House of Representatives a message explaining that in his view Tennessee had been entitled to representation well before the resolution passed. ${ }^{155}$

Tennessee had a lot of company in ratifying, but none of it was in the South. ${ }^{156}$ Southerners were encouraged in resisting the amendment by President Johnson, who participated vigorously in the off-year

150 Bill reported in the House (Apr 30, 1866), in McPherson, Reconstruction at 103-04 (cited in note 92).

151 See Cong Globe, 39th Cong, 1st Sess 2286-87 (Apr 30,1866) (tabling both the resolution for an amendment and the readmission); id at 2530-45 (May 10, 1866) (adopting the resolution but not passing the bill).

152 See id at 3148-49 (June 13, 1866) (reporting vote and passage).

1531 USC LXIII (listing ratifications).

154 JR 73 (July 24, 1866), 14 Stat 364.

155 President Johnson registered his objections to the congressional reconstruction plan:

Earnestly desiring to remove every cause of further delay, whether real or imaginary, on the part of Congress to the admission to seats of loyal Senators and Representatives from the State of Tennessee, I have, notwithstanding the anomalous character of this proceeding, affixed my signature to the resolution. My approval, however, is not to be construed as an acknowledgment of the right of Congress to pass laws preliminary to the admission of duly qualified Representatives from any of the States.

Andrew Johnson, Special Message to the House of Representatives (July 24, 1866), in Richardson, ed, 6 Messages and Papers of the Presidents at 397 (cited in note 14). Once again, Johnson disclaimed any power to interfere with the duty of each house of Congress, acting separately, to judge the elections, returns, and qualifications of individual claimants to seats. Id. But he reiterated the view that there was nothing wrong with the southern states as such, and that they were entitled to representation "when they present themselves in the persons of loyal Senators and Representatives who can comply with all the requirements of the Constitution and the laws." Id.

156 Six states, including Tennessee, ratified in 1866: Connecticut (June 25), New Hampshire (July 6), Tennessee (July 19), New Jersey (September 11), Oregon (September 19), and Vermont (October 30). 1 USC LXIII. McKitrick lists the dates on which the ten other ex-Confederate States voted down ratification. See McKitrick, Andrew Johnson at $358 \mathrm{n} 54$ (cited in note 86). 
campaigning, denouncing Congress for extremism in reconstruction. ${ }^{157}$ When the voters went to the polls, the Democrats, whom Johnson had in effect supported, got their clock cleaned. The Fortieth Congress would have crushing Republican majorities. ${ }^{158}$

Before the new Congress convened, however, the Thirty-ninth Congress would meet for its lame duck session starting in December 1866. After much debate and intricate parliamentary infighting, that session passed the first Military Reconstruction Act over Johnson's veto. ${ }^{159}$ Due to last minute maneuvering the Act sought to deal with two distinct but related problems: the failure of the first-round regimes to provide adequate protection to freed people and Unionists, and the need to replace the first-round governments with more regularly established regimes that would rest on race-blind loyal suffrage.

The Act began by announcing that "no legal State governments or adequate protection for life or property now exists" in the ten states not represented in Congress, and that it was necessary "that peace and good order should be enforced in said States until loyal and republican State governments can be legally established."161 The first step was military government. The South was divided into five military districts, each to have a commander, whose duty it would be "to protect all persons in their rights of person and property, to suppress insurrection, disorder, and violence, and to punish, or cause to be punished, all disturbers of the public peace and criminals." ${ }^{, 162}$ To that end the commander could allow the local tribunals to take jurisdiction and punish offenders or could "organize military commissions or tribunals for that purpose, and all interference under color of State authority with the exercise of military authority under this act shall be null and void." ${ }^{163}$ That is, no habeas corpus relief was to be granted by the state courts.

157 See Randall and Donald, The Civil War and Reconstruction at 589-91 (cited in note 40) (recounting the election campaign of 1866). The best known episode was his speaking tour in August and September, the "swing around the circle" of large cities, in which Johnson railed on his opponents in intemperate terms and traded insults with critics in the crowd. Id at 589 (internal quotations omitted).

158 Not counting ex-Confederate States other than Tennessee, the Senate would have fortyfive Republicans and nine Democrats, although according to James G. Blaine three of the Republicans supported President Johnson. Blaine, 2 Twenty Years at 284 (cited in note 86). The House would have 148 Republicans and 41 Democrats. Id at 285-86.

159 Act of March 2, 1867, ch CLIII, 14 Stat 428.

160 McKitrick describes the sometimes confusing process by which the act was drafted. McKitrick, Andrew Johnson at 473 85 (cited in note 86 ). As he explains, the statute that emerged was "a product of intense and extended debate, the results of which were not anticipated at the beginning nor the implications entirely appreciated even at the end." Id at 473.

161 Act of March 2, 1867, ch CLIII, Preamble, § 2, 14 Stat 428.

162 Id $\S 3$.

163 Id.

164 Interference by the state judiciaries with military control of violence had been an issue 
Having put the southern states under military supervision, Congress offered them a way out: form new governments that satisfied Congress's notions of validity and republican form, and ratify the Fourteenth Amendment. Republican form and loyalty meant raceblind loyal suffrage. ${ }^{165}$ Until senators and representatives had been admitted pursuant to those terms, the Act provided that "any civil governments which may exist therein shall be deemed provisional only, and in all respects subject to the paramount authority of the United States at any time to abolish, modify, control, or supersede the same." $" 166$

Republicans quickly realized that, whether by accident or design, they had left out an important piece of the reconstruction machinery: a starter. Although the first act described the kind of new southern constitution that would satisfy Congress, it did not charge anyone with conducting the elections that would produce those constitutions." When the Fortieth Congress convened immediately in the wake of the Thirty-ninth, it had to decide whether the federal government should set the process going. ${ }^{168}$ Before the end of March it had passed another reconstruction act designed to do just that. ${ }^{169}$ The first supplementary act instructed the military commanders to register voters and then conduct an election at which the people would vote both for delegates to a convention and on the question whether to hold the convention." If a majority of all registered voters decided to have a convention, the commanding general was to summon the delegates and then to con-

in the debates. McKitrick, Andrew Johnson at 455-60 (cited in note 86).

165 Section 5 of the Act provided that military rule would end, and the state involved would be "declared entitled to representation in Congress, and senators and representatives [would] be admitted therefrom on their taking the [ironclad] oath prescribed by law" when the following had happened:

(1) a convention had formed and a majority of the people had ratified a constitution in conformity with the Constitution of the United States, suffrage in electing the convention and voting on the proposed constitution being confined to "the male citizens of said State, twenty-one years old and upward, of whatever race, color, or previous condition, who have been resident in said State for one year previous to the day of such election, except such as may be disenfranchised for participation in the rebellion or for felony at common law";

(2) the new constitution provided for suffrage by those who could vote for the convention;

(3) Congress had approved the new constitution;

(4) the state legislature had ratified the Fourteenth Amendment; and

(5) the amendment had become part of the Constitution.

Act of March 2, 1867, $\$ 5,14$ Stat at 429. Moreover, the Act barred from voting for or serving in the convention anyone barred from federal office by Section 3 of the proposed amendment.

166 Id $\S 6$.

167 See McKitrick, Andrew Johnson at 483-84 (cited in note 86) (noting confusion over the bill).

168 Id at 484.

169 Act of March 23, 1867, ch VI, 15 Stat 2.

170 Id $\S \S 1-4,15$ Stat at 2-3. 
duct a referendum on the constitution they drafted. ${ }^{171}$ If that constitution was approved, it was to be submitted to Congress, which was to decide whether the referendum had been free and fair, whether the requisite majority had been obtained, and whether the new constitution was in conformity with the reconstruction acts. ${ }^{172}$ If Congress so declared, the state involved was to be entitled to representation and its senators and representatives to be admitted, assuming they were individually qualified."

Congress, however, was not finished with reconstruction legislation. In May and June 1867, Attorney General Stanbery produced opinions that took a restrictive view of the first two reconstruction acts. ${ }^{174}$ Stanbery concluded that the military's power with respect to the existing civil governments was restricted to that which was necessary to maintain order, prevent insurrection, and punish crime. ${ }^{175}$ Congress responded in July with another supplementary act that gave the military authorities complete power over the existing civil governments, undid most of the rest of Stanbery's work, and instructed the military officers to stop listening to the Attorney General. ${ }^{176}$

While all this took place in Washington in the first half of 1867 , states were acting on the Fourteenth Amendment. As more legislatures convened, more ratifications came in. By the end of June twentytwo states had ratified, counting Tennessee. ${ }^{17}$ As will be discussed presently, some Republicans thought that the amendment itself had thereby been ratified too.

As the federally sponsored elections and conventions got under way, opponents of the proposed new regimes thought they saw a weakness in the congressional plan. Under the Reconstruction acts, ratification of a new constitution required a majority of all registered voters, not just a majority of those who voted on ratification. So the lazy southerner's way to resist was to register, but then not show up on

171 Id \& 4, 15 Stat at 3.

172 Id $\S 5,15$ Stat at $3-4$.

173 Id.

17412 Op Atty Gen 141 (May 24, 1867) (Henry Stanbery, AG); 12 Op Atty Gen 182 (June 12, 1867) (Henry Stanbery, AG).

17512 Op Atty Gen at 188-89.

176 Act of July 19,1867 , ch XXX, 15 Stat 14 . Section 2 gave the military commanders power "to suspend or remove from office, or from the performance of official duties and the exercise of official powers, any officer or person holding or exercising, or professing to hold or exercise, any civil or military office or duty," and "to provide from time to time for the performance of the said duties of such officer or person so suspended or removed, by the detail of some competent officer or soldier of the army, or by the appointment of some other person, to perform the same, and to fill vacancies occasioned by death, resignation, or otherwise." Id $\S 2$. Section 10 provided that no commander would be "bound in his action by any opinion of any civil officer of the United States." Id $\S 10,15$ Stat at 16.

177 See 1 USC LXIII (listing ratifications). 
election day. A concerted effort in this regard worked in Alabama, at least according to General Meade's initial count. ${ }^{178}$ To keep this trick from working again, the Republicans passed another Reconstruction Act in March 1868 that authorized ratification by a majority of the votes cast."

On June 22, 1868, Congress enacted a statute declaring that Arkansas, first of the congressionally-reconstructed states to qualify, had complied with all requirements and was entitled to representation. ${ }^{180} \mathrm{~A}$ few days later, the dam burst and an omnibus bill provided for the admission to representation of North Carolina, South Carolina, Louisiana, Georgia, Alabama, and Florida as soon as their legislatures ratified the Fourteenth Amendment. ${ }^{181}$ Including Alabama in that list had been controversial, because its referendum on the new constitution had been held before Congress moved the goalposts. ${ }^{182}$

The remaining three southern states presented greater difficulties, and misbehavior by the Georgia legislature for a while cast that state's status into doubt. ${ }^{183}$ Virginia was restored in January 1870, Mississippi in February, Texas in March, and Georgia (again) in July $1870 .^{184} \mathrm{Be}-$ fore their admission Virginia and Mississippi ratified the Fourteenth Amendment, and Texas, where the first-round convention had not met until 1866, ratified the Thirteenth Amendment as well. ${ }^{185}$ With the restoration of Georgia, congressional reconstruction was over, and no state has been excluded from Congress since.

As the ratifications came in from the congressionallyreconstructed legislatures in 1868 , the federal executive branch played a game with them. Under the omnibus readmission act, the President was required to certify ratifications to Congress. ${ }^{186}$ President Johnson, having taken the position in his veto messages that the earlier regimes had been valid and that Congress therefore had no business arranging for the creation of new ones, referred to notice of ratification coming from someone who "writes himself Governor." In similar fashion,

178 See Walter L. Fleming, Civil War and Reconstruction In Alabama 536-42 (Columbia 1905) (recounting difficulties with ratification of Alabama Constitution).

179 Act of March 11,1868, ch XXV, 15 Stat 41.

180 Act of June 22, 1868, ch LXIX, 15 Stat 72.

181 Act of June 25, 1868, ch LXX, 15 Stat 73.

182 See Fleming, Civil War at 540-41 (cited in note 178) (noting that the voting occurred in February).

183 See C. Mildred Thompson, Reconstruction in Georgia: Economic, Social, Political, 18651872 255-75 (Columbia 1915) (describing events in Georgia).

184 See Act of January 26, 1870, ch X, 16 Stat 62 (restoring Virginia); Act of February 23, 1870, ch XIX, 16 Stat 67 (restoring Mississippi); Act of March 30, 1870, ch XXXIX, 16 Stat 80 (restoring Texas); Act of July 15, 1870, ch CCXCIX, 16 Stat 363 (restoring Georgia).

185 See 1 USC LXII-LXIII (listing ratifications).

186 Act of June 25,1868 , ch LXX, $\$ 3,15$ Stat at 74.

187 In response to notification from South Carolina, President Johnson proclaimed that "on 
Secretary of State Seward issued a conditional proclamation of the amendment, one that did not actually take a position as to whether it had been ratified. In describing the situation he referred to ratifications from "newly constituted and newly established bodies avowing themselves to be and acting as the legislatures, respectively, of the States of Arkansas, Florida, North Carolina, Louisiana, South Carolina, and Alabama." majority passed a concurrent resolution declaring the amendment adopted and directing the Secretary to promulgate it, which he did. ${ }^{189}$

And as Chief Justice Hughes put it about a lifetime later, " $[\mathrm{t}] \mathrm{his}$ decision by the political departments of the Government as to the validity of the adoption of the Fourteenth Amendment has been accepted." ${ }^{190}$ The Thirteenth and Fifteenth Amendments have been accepted too.

\section{B. What Were They Thinking?}

But should they have been? The process just described was, to say the least, extraordinary. Eleven states had gone through political convulsions in which governments were created and destroyed. Objections were raised to the legality of the processes that created all twenty-one of the reconstructed governments and to the validity of their official acts. It was also unheard of to use federal power to press constitutional amendments on the states. All those who participated in reconstruction, including those who were paying attention to the process of constitutional amendment, knew that something very unusual and legally doubtful was going on. Yet the vast bulk of Republicans and some Democrats seem to have believed that both the Thir-

the eighteenth day of July, one thousand eight hundred and sixty-eight, a letter was received by the President, which letter ... was transmitted by and under the name of R. K. Scott, who therein writes himself Governor of South Carolina" and which announced that South Carolina had ratified. Andrew Johnson, Proclamation No 8, July 18, 1868, 15 Stat Appendix 704, 704.

188 William H. Seward, Proclamation No 11, July 20, 1868, 15 Stat Appendix 706, 707. In addition to alluding to the problem of the congressionally-reconstructed states, Seward also recited that the legislatures of Ohio and New Jersey had adopted resolutions purporting to rescind their earlier ratifications and that it was "a matter of doubt and uncertainty whether such resolutions are not irregular, invalid, and therefore ineffectual for withdrawing the consent of the two said States." Id. Seward certified "that if the resolutions of the legislatures of Ohio and New Jersey ratifying the aforesaid amendment are to be deemed as remaining of full force and effect, notwithstanding the subsequent resolutions of the legislatures of those States, which purport to withdraw the consent of said States from such ratification, then the aforesaid amendment has been ratified." Id.

189 William H. Seward, Proclamation No 13, July 28, 1868, 15 Stat Appendix 708. Seward quoted in full the concurrent resolution directing him to promulgate the amendment. Id at 709 10 (stating that the validity of the ratification of the Fourteenth Amendment by a state legislature that had previously rejected the Amendment was to be determined by the Congress, not the Court).

190 Coleman v Miller, 307 US 433, 449-50 (1939). 
teenth and Fourteenth Amendments had been validly ratified. What were they thinking?

No doubt many of them were thinking that ratifying the Amendments was right or at least an unavoidable political compromise, that the law authorizes what the country needs, and that the details could take care of themselves. Many participants, however, did address the legal issues more explicitly.

\section{The reduced denominator theory.}

A large number of Republicans believed, or at least asserted, that southern ratifications were irrelevant because the seceded states were not properly included in the Article $\mathrm{V}$ denominator. It is exceptionally important to understand that this conclusion could be reached by more or less radical routes, and that those who took the truly radical routes seem to have been in the minority among Republicans. Two of the main theories of reconstruction led automatically to a reduced denominator. If the eleven states had in fact seceded and been conquered, they did not count any more than the Mexican province of Alta California counted after American troops seized it (but before it became the State of California). ${ }^{191}$ If a political act of the people had destroyed those states as such, making their land into federal territory and their inhabitants into American citizens not resident in any state, then once again they were irrelevant to Article V. ${ }^{192}$

But while the conquered provinces and territorial status theories attracted few followers among Republicans, many members of that party nevertheless believed that the extraordinary events of the preceding years had removed the ex-Confederate States from the Article $\mathrm{V}$ denominator without removing them from the Union. The germ of this more moderate theory seems to have come from Representative Shellabarger's destroyed governments thesis, according to which the seceding states had wiped clean the slate of their political laws. ${ }^{193}$

One result was that they had, for the time being, no lawful legislature that could act on a constitutional amendment. According to Charles Sumner, a state without a legislature did not count in calculating the Article V supermajority. ${ }^{194}$ In broader terms, the seceded states

191 See the conquered provinces thesis in text accompanying note 83 .

192 See text accompanying note 84 . Representative George W. Julian in 1867 embraced the territorial status theory and deduced the consequence that the former states did not count under Article V. Cong Globe, 39th Cong, 2d Sess Appendix 77-80 (Jan 28, 1867).

193 See Cong Globe, 39 th Cong, 1st Sess $142-45$ (Jan 8, 1866). See also notes 86-88 and accompanying text.

194 Early in the second session of the Thirty-ninth Congress, Sumner introduced a resolution stating that states without lawful legislatures were not entitled to representation in Congress and did not count in the Article V denominator. Cong Globe, 39th Cong, 2d Sess 15 (Dec 5, 1866). In January 1868 Sumner explained his textual reasoning. 
were out of their practical relations with the Union, and therefore did not count in the denominator. That was John Bingham's formulation." By disrupting the election of senators and representatives, rebellion could take a state out of those relations, just as it could paralyze the state domestically by eliminating its loyal government. Bingham's formulation seems to have been especially attractive to Republicans because it naturally suggested, and Bingham espoused, a test to determine whether a state was or was not maintaining practical relations with the United States: whether Congress believed it currently entitled to senators and representatives. As long as the southerners were excluded from Congress, Bingham believed, their states were temporarily excluded for Article $V$ purposes.

If this theory is correct, most of the objections to the amendment process vanish, and the Amendments were ratified well before the Secretary of State promulgated them. When the Thirteenth Amendment was proposed, twenty-six out of thirty-six states were represented in Congress, if one counts Virginia, which was hanging on by a single senator. ${ }^{196}$ After March 4, 1865, twenty-five states were repre-

An amendment, when proposed, "shall be valid to all intents and purposes as part of this Constitution when ratified by the Legislatures of three fourths of the several States." It does not say "when ratified by three fourths of the several States," but "by the 'legislatures' of three fourths of the several States." Now, if there are States without Legislatures, they can have no voice in the ratification.

Cong Globe, 40th Cong, $2 \mathrm{~d}$ Sess 878 (Jan 31,1868 ). Evidently Sumner had moved away from the theory that the states had simply destroyed themselves as such.

195 "I believe that the sovereignty of the nation is alone in the organized constitutional States of this Union, maintaining their relations to the Federal Government, and represented in the Congress of the United States." Cong Globe, 39th Cong, 2d Sess 500 (Jan 16, 1867) (Rep Bingham). From that premise Bingham deduced several conclusions, one of which had to do with Article V. He sustained "the power of the loyal organized States here represented to ratify [the pending Fourteenth Amendment] and make it part of the Constitution of the United States." Id at 501. Bingham also asserted that while a state was disorganized, Congress had exclusive power to legislate for it. Id at 500 .

196 At that point claimants from Louisiana and Arkansas had not been seated. Virginia's only member of either house was Senator John Carlile, whose term was about to expire at the end of the Thirty-eighth Congress in March 1865. (Carlile had been elected by the Wheeling, Virginia legislature to fill out a term that began in March, 1859.) Ambler, Pierpont at 113 (cited in note 17). His colleague, Lemuel Bowden, had died in January, 1864. Cong Globe, 30th Cong, 1st Sess 147 (Jan 11, 1864) (announcing Bowden's death). (Bowden had been elected to a six-year term beginning in March, 1863. Cong Globe, 37th Cong, 3d Sess 1426 (Mar 2, 1863).) The Alexandria, Virginia legislature elected John Segar to serve out Bowden's term, and on February 17, 1865, Waitman Willey, then a senator from West Virginia and previously a senator from Virginia elected by the Wheeling legislature, presented Segar's credentials. Cong Globe, 38th Cong, 2d Sess 845 (Feb 17, 1865). After a debate on the status of the Alexandria government, Segar's credentials were tabled. Id at 845-49. Meanwhile, the Alexandria legislature had elected John C. Underwood to succeed Carlile for a term that would run from March, 1865 through March, 1871. Ambler, Pierpont at 227 (cited in note 17). A Special Session of the Senate of the Thirty-ninth Congress convened in March 1865, and Senator Doolittle presented Underwood's credentials. See Cong Globe, 38th Cong, 2d Sess 1433 (Mar 9, 1865). (The records of the Special Session of the Senate of the Thirty-ninth Congress appear in the Congressional Globe for the second ses- 
sented. ${ }^{197}$ Three-fourths of twenty-five is nineteen, and on July 1,1865 , New Hampshire was the nineteenth represented state to ratify. ${ }^{198}$ By the time the Fourteenth Amendment had been proposed, Nebraska had been admitted to the Union and to representation in Congress, so the total number of states was thirty-seven and the number of represented states was twenty-six. Tennessee was admitted to representation before three-fourths of the represented states had ratified, raising the denominator to twenty-seven. Three-fourths of twenty-seven is twenty-one, and on March 20,1867, Massachusetts was the twenty-first represented state to ratify, counting Tennessee. ${ }^{199}$ If one believes that Tennessee should not count in the numerator because its ratification had been coerced, the Amendment went into effect when Nebraska ratified on June 15,1867 , while the number of represented states was still twenty-seven.

Those who embraced this theory were unembarrassed by the claim that the Military Reconstruction Acts called the Thirteenth Amendment into question when they branded the first-round governments as illegal. ${ }^{201}$ Nor were they troubled by the assertion that the ratifications of the Fourteenth Amendment by unrepresented states

sion of the Thirty-eighth Congress.) The Senate postponed consideration of Underwood's credentials until its next session, the first session of the Thirty-ninth Congress, which would convene in December 1865. Id at 1434. It then took Segar's credentials from its files and postponed them too. Id at 1434-35. Segar and Underwood were thus included among the southern claimants whose credentials were referred to the Joint Committee on Reconstruction. From the expiration of Carlile's term in March, 1865, to Virginia's readmission to representation in 1870, no senator or representative from Virginia sat in Congress.

197 See Cong Globe, 38th Cong, 2d Sess 1424 (Mar 4, 1865) (listing Senators from twentyfive states).

1981 USC LXIII. Counting New Hampshire as the nineteenth and decisive state assumes that the denominator fell from twenty-six to twenty-five when Virginia ceased to be in practical relations with the Union. It does not count the ratification by the Alexandria, Virginia legislature on February 2,1865. That ratification did take place while Virginia was represented by Senator Carlile, so if the denominator was fixed at twenty-six and twenty states were needed even after Virginia ceased its practical relations, then Virginia should count and New Hampshire was the twentieth and conclusive ratifying state. The nineteen or twenty that culminates with New Hampshire does not count ratifications by the Lincoln-reconstructed legislatures of Louisiana, Tennessee, and Arkansas, which ratified on February 17, April 7, and April 14, respectively. Id. According to Bingham's theory, those states would in no circumstances count in the denominator because they were not represented when the amendment was proposed or when it was adopted.

199 Id. On March 11, 1867, Representative Bingham stated that the Fourteenth Amendment had been ratified. Cong Globe, 40th Cong, 1st Sess 64 (Mar 11, 1867). On January 11, 1868, Senator Sumner introduced Senate Resolution 86, declaring the Fourteenth Amendment ratified. Cong Globe, 40th Cong, 2d Sess 453 (Jan 11, 1868).

200 Cong Globe, 40th Cong, 2d Sess 453 (Jan 11, 1868).

201 See Andrew Johnson, Veto Message, Mar 2, 1867, in Richardson, ed, 6 Messages and Papers of the Presidents at 508 (cited in note 14). 
were being extorted from them. According to this view those ratifications were a pledge of loyalty, not a constitutional necessity. ${ }^{202}$

It is impossible to be sure how many Republicans believed that a state did not count in the denominator while it was out of its practical relations with the Union. Not everyone addressed the issue, a few equivocated, and some who professed the theory may not really have believed it. But quite a few professed it. As noted, the list includes Charles Sumner and John Bingham, who were important and influential figures despite a talent for rubbing their colleagues the wrong way. A more politick proponent was Schuyler Colfax, Speaker of the House (and Grant's first Vice President). ${ }^{203}$ Senator Lyman Trumbull, Chairman of the Senate Judiciary Committee and a prominent Supreme Court lawyer, at one point counted himself a supporter, although at another time he was softer in his endorsement. ${ }^{204}$ Several other Republicans adopted the theory. ${ }^{205}$ A few came out explicitly

202 See remarks of Senator Stewart in note 205.

203 On March 17, 1868, Speaker Colfax stated that in his view the Fourteenth Amendment was part of the Constitution. See Cong Globe, 40th Cong, 2d Sess 1928 (Mar 17, 1868).

204 On January 23, 1868, Senator Trumbull, responding to Senator Doolittle's argument that the Thirteenth Amendment had been submitted to the seceded states, said that their votes were not necessary for its ratification. See Cong Globe, 40th Cong, 2d Sess 709 (Jan 23, 1868). In March 1868, discussing a bill to remove political disabilities, Trumbull explained that the Judiciary Committee had drafted the bill so as to avoid the question whether the Fourteenth Amendment, which would add to the disabilities imposed by statute, was part of the Constitution. Id at 1978 (Mar 19, 1868). A few months later, during debate on the readmission of Arkansas, Trumbull was cagey, stating that some said the Fourteenth Amendment was already ratified and he was not prepared to say they were wrong, but that it soon would be ratified beyond all doubt. Id at 2602 (May 27, 1868). Two days later, Senator Edmunds addressed these remarks to Trumbull: "I ask my honorable friend from Illinois, has it become so [ratified]? My friend is unwilling to say that it has. I do not know what his individual opinion is. I can scarcely say that I know what my own is." Id at 2662 (May 29, 1868). Senator Edmunds went on to say that he was inclined against the reduced denominator theory, but that in any event ratification should not be left in doubt. Id.

205 On January 28, 1867, Representative Collum said that the Fourteenth Amendment would become part of the Constitution when ratified "by three fourths of the States in their practical relations to the Government." Cong Globe, 39th Cong, 2d Sess 814 (Jan 28, 1867). The next month Senator Stewart said that "we all hold that that [Amendment] may be ratified by the loyally represented States without them, and the only object of having them recognize it is to show their loyalty to this Government." Id at 1392 (Feb 15, 1867). See also id Appendix at 176 (Feb 9, 1867) (Rep Banks stating that three-fourths of represented states may ratify an amendment); Cong Globe, 40th Cong, 1st Sess, Appendix 28 (July 20,1867) (Rep Lawrence stating that three-fourths of the states with legal state governments can ratify).

Senator Wilson said that in his view the Fourteenth Amendment had already been ratified as of May 30,1868, but that many able minds doubted or denied it, so the southern states should be admitted to representation and their ratifications counted. See Cong Globe, 40th Cong, $2 \mathrm{~d}$ Sess 2691 (May 30, 1868).

The Nation likewise adopted the reduced denominator theory. When the Fourteenth Amendment was close to passage in Congress, that Republican journal stated that the consent of the revolted states was not needed for its ratification. 2 Nation 673 (May 28, 1866). A few days after Congress proposed the amendment, The Nation prophesied that it was "almost certain to be ratified by three-fourths of the States at present lawfully organized." 2 Nation 744 (June 11, 
against. ${ }^{206}$ Some were uncertain. ${ }^{207}$ Some endorsed a reduced denominator theory without saying which one. ${ }^{208}$

As should not surprise us, their stated views on this legal question depended on the political situation. In 1868, as Congress was deciding whether to admit the congressionally-reconstructed regimes to representation in Congress, some said that it would be wise to have threefourths of all the states to quell all doubts. ${ }^{209}$ Admission would ratify the states' ratification of the Amendment. It also would bring in $\mathrm{Re}$ publican senators and representatives. At that point, ratification to dispel doubts seems to have become more important to some Republicans.

\section{The congressional recognition power.}

While a substantial number of Republicans espoused this theory and at least some of them probably believed it, they knew that not everyone did and in particular that not every judge or justice necessarily would. They also knew that not everyone agreed with their claim, based on Shellabarger's destroyed governments theory, that Congress had substantial authority under the Guarantee Clause to rebuild the political structures that the seceding states had razed to the ground. ${ }^{210}$ By what must have struck them as a wonderful irony, however, Chief Justice Taney had supplied them with a powerful weapon in the legal struggle over reconstruction.

1866). The southern states, it maintained, were disorganized, and Congress had power to summon conventions that would create lawful governments for them. Id at 745 .

206 Senator Charles Drake, Republican of Missouri, rejected the reduced denominator theory during the debate on Arkansas's admission to representation on May 28, 1868. Cong Globe, 40th Cong, 2d Sess 2628 (May 28, 1868). He then hedged a little, saying that it would take twentyeight states "to give satisfaction and peace to the people of this country, and the conviction that it is rightfully done." Id.

207 Representative George Miller, Republican of Pennsylvania, said on January 19, 1867: "[Determination of the number of states needed for ratification] is a question too important to theorize upon, as there is no telling what the Supreme Court of the United States, as now or shall hereafter be constituted, may decide in regard to the status of these ten insurrectionary States." Cong Globe, 39th Cong, 2d Sess, Appendix 83 (Jan 19, 1867).

208 See, for example, Cong Globe, 39th Cong, 2d Sess 255 (Jan 3, 1867) (Rep Pike stating, "[w]e shall adopt the amendment by means of three fourths of the loyal States"); id at 288 (Jan 5, 1867) (Rep Spaulding stating "ratification of that amendment by three fourths of the loyal States was sufficient to make it part of the Constitution").

209 In the summer of 1868 , while the Senate was considering the readmission of six states, Senator Sherman maintained that it was a matter of doubt whether the Fourteenth Amendment had been ratified, because it was not clear how many states counted in the denominator, and that admission of the southern states would dispel those doubts. See Cong Globe, 40th Cong, 2d Sess 2860 (June 5, 1868).

210 See Andrew Johnson, Veto Message, Mar 2, 1867, in Richardson, ed, 6 Messages and Papers of the Presidents at 498-511 (cited in note 14). 
Under Luther $v$ Borden ${ }^{211}$ as they understood it, Congress could quell any doubts about the validity of the second-round regimes by admitting them to representation and thereby blessing them as republican and lawful. ${ }^{212}$ The courts would be bound by that determination. Lyman Trumbull announced this doctrine in both the old and new Senate chambers, expounding it in debate and before the Supreme Court in Ex parte McCardle. ${ }^{213}$ Many Republicans were familiar with the principle.

Luther would give the Fourteenth Amendment a firm footing. Once Congress had declared a state entitled to representation, the actions of the state government so recognized would be conclusively established as the actions of the state. 213 Ratification by Tennessee and

21148 US ( 7 How) 1 (1840).

212 Id at 42. Luther and its doctrine are discussed in detail in Part II.B.1.

213 In the Senate on July 1,1868 , Senator Trumbull relied on Luther for the proposition that congressional recognition of the new southern governments was final and binding, and that resistance to them would be revolution. See Cong Globe, 40th Cong, 2d Sess 3630-31 (July 1, 1868). In the Court, Trumbull invoked Luther for the proposition that the status of a state was a political question for Congress. See Oral Argument of Lyman Trumbull, Ex Parte McCardle, 74 US (7 Wall) 506 (1869), reprinted in Philip B. Kurland and Gerhard Casper, eds, 5 Landmark Briefs and Arguments of the Supreme Court of the United States: Constitutional Law 375, 377 (University Publications 1975). Trumbull also used the opportunity to expound the destroyed governments theory:

That chain which made Mississippi a State in 1817 was broken when she set up a government in hostility to the government of the United States. It ceased then to be a State of the American Union; that is to say, its political organization as a State of the American Union was destroyed.

Id at 379.

214 See, for example, Cong Globe, 40th Cong, 2d Sess 512-13 (Jan 14, 1868) (Rep Bingham stating that congressional judgments under the Guarantee Clause are binding on the courts); id at 2118-19 (Mar 26,1868) (Sen Stewart explaining that Republicans have no fear of the Supreme Court because it has no power to decide the status of the southern states); id at 3912 (July 10, 1868) (Sen Conkling, referring to Luther as supporting the premise "that to Congress as the lawmaking power, or political power of the country, belongs the recognition or the refusal to recognize a State government in any particular State as the legitimate government there.").

Democrats and Johnson Republicans had read the case too. Senator Buckalew of Pennsylvania, a Democrat for practical purposes, was asked by Senator Edmunds, "where does the rightful power in this Government reside of determining what is a State; what political community pretending or asserting itself to be a State is a true State that belongs to the Union?" Id at 3879 (July 9, 1868). Buckalew replied that he was familiar with Luther, but that in certain cases the courts may have to decide the question for themselves as an original matter. Id.

The Nation also had considerable confidence in the doctrine of Luther. In early 1867 it explained that under that case the courts would be bound by Congress's endorsement of the second-round governments: Congress's choice between two sets of state conventions, both representing only part of the people and both summoned by national authority, would not be questioned. 4 Nation 10 (Jan 3,1867). Later that year the point was made again. "The work of reorganization must go on; and when it is completed, the decision of Congress will make valid whatever may have been irregular, leaving no choice for the courts but to recognize the governments which Congress has approved." 4 Nation 394 (May 16, 1867).

215 Republicans also seemed to be confident that congressional recognition would relate back to prior state actions, including especially ratification of constitutional amendments. See 
the congressionally-reconstructed states would be unassailable. ${ }^{216}$ At least, the actions of the congressionally-recognized governments would be unassailable. But most of the southern ratifications of the Thirteenth Amendment had come from first-round governments, of which all but Tennessee's had been declared illegal and provisional only by the first Military Reconstruction Act. How did the Republicans think they could keep those ratifications?

I have been unable to find a straight answer to this question, perhaps because Republicans were unwilling to commit themselves to any one theory. It is possible, however, to engage in some informed speculation. First, many Republicans may have believed that the southern ratifications of the Thirteenth Amendment had been valid of their own force, even without congressional sanction. When it came to the legal effectiveness of the first-round governments, Republicans' bark generally was worse than their bite. Both before and after the first Military Reconstruction Act was adopted, many of them recognized that the southern governments were effective for at least some purposes. ${ }^{217}$ Indeed, the Act recognized those governments as provisional, a backhanded way of saying that they had some authority.

Cong Globe, 39th Cong, 2d Sess 501 (Jan 16,1867) (Rep Bingham noted that the "insurrectionary States may proceed with ... the formal ratification of the constitutional amendment and all that they do in that behalf may by the subsequent act of the national sovereignty by resolution be made valid.") (Jan 16, 1867); id Appendix 75 (Jan 17, 1867) (Rep Baker also noted that not until the bill that restored the states to their full political rights passed would the "de facto State governments" be recognized.).

216 Representative Lawrence gave another example of political-branch finality at work. The Virginia government at Wheeling had been recognized by the political departments, he explained, and therefore its consent to the creation of West Virginia could not be questioned. See Cong Globe, 40th Cong, 2d Sess 182 (Dec 13, 1867).

217 Before the first Military Reconstruction Act passed, even Thaddeus Stevens said that the first-round governments were municipal institutions for going on from day to day. Cong Globe, 39th Cong, 2d Sess 291 (Jan 5, 1867). After the first Act had been adopted, Senator Frelinghuysen of New Jersey maintained that the first-round governments retained some authority, so that their courts could exercise judicial power and their legislatures could borrow on the credit of the state. See Cong Globe, 40th Cong, 1st Sess 136 (Mar 16, 1867). In the summer of 1867, Senator Trumbull maintained that the southern governments were provisional in the sense that they were not utterly null and void but were subject to congressional control. Id at 523 (July 9, 1867). Trumbull must not have believed that the first-round governments were void ab initio and totally hopeless as a legal matter, for in that speech he also said that had they been in the hands of loyal men Congress would have recognized them and military reconstruction never would have happened. Id. Even arch-Radical Senator Howard of Michigan recognized that the first-round governments existed as a matter of fact, although he took a very narrow view of their legal authority. Id at 550-51 (July 10,1867). He believed that their de facto status meant that their citizens would have to pay the debts the governments contracted. Id at 654 (July 15, 1867).

218 Senator Fessenden, Chairman for the Senate of the Joint Committee on Reconstruction, believed that the first Reconstruction Act gave considerable recognition to the very regimes it denounced:

They were governments elected by the people in a certain way. We have recognized their legal existence as governments in these States. We have said in the very act that we passed at the last session that they are provisional governments. We have established that fact. It is 
Some may have thought that the first-round governments retained their legal authority until Congress explicitly legislated to the contrary. $^{219}$ Whatever individuals may have thought, we do know that Congress, aware of the continued operation of the first-round governments, never accepted the suggestion that they simply be dissolved and never provided that nothing they did or had done had any legal effect. ${ }^{20}$ While Congress on a few occasions acted to undo some specified act of a "provisional" government, it certainly never did so with respect to ratification of the Thirteenth Amendment.

Second, some may have believed that congressional recognition of the second-round governments would retrospectively validate actions of the first-round governments. The idea seems to have been that a new permanent government, as the successor to a provisional government, would take over what had been done in the state's name during the provisional period. Both were governments of the same state and hence there was inevitably substantial continuity. ${ }^{222}$ That continuity was stressed by the second-round Supreme Court of North Carolina in a case upholding the jurisdiction of a lower state court established under the first-round regime. "Our present government was formed under the same authority which organized and sustained the

no longer in our mouths to deny, in any shape or form, that they are legal provisional governments in these States after we have made them so-not legal State governments; that we deny; but legal provisional governments. We have legalized them.

Cong Globe, 40th Cong, 1st Sess 96 (Mar 14, 1867).

219 Senator Timothy Howe, for example, stated in March 1867 that Congress, through the first Military Reconstruction Act, had just changed the legal status of the existing southern governments. Id at 137 (Mar 16,1867).

While the Republicans were tying themselves into the knot that Senator Fessenden described, Senator Thomas Hendricks of Indiana, a Democrat, had some fun with their equivocation, asking just what it meant to have an unlawful but lawful provisional government subject to a military government. Id at 157.

220 For example, in January 1868 Senator Morton introduced a resolution that would have abrogated the then-existing southern governments and replaced them with congressionallycreated provisional governments, see Cong Globe, 40th Cong, 2d Sess 384 (Jan 8, 1868), but the resolution was not adopted. Recognition of the southern regimes even as provisional had been a subject of controversy while the first Military Reconstruction Act was drafted. Representative Paine, for example, objected to acceptance of those governments even for municipal purposes. He maintained that they were highly objectionable and should get no recognition from Congress. See Cong Globe, 39th Cong, 2d Sess 499 (Jan 16, 1867).

221 See, for example, Resolution No 8 (Feb 18, 1869), 15 Stat 344 (providing for removal of officers in provisional governments of Virginia and Mississippi who could not take the specified oath).

222 Representative Lawrence of Ohio seemed to think that there was substantial continuity between the two sets of southern governments. Lawrence was among those who stated explicitly that congressional recognition of a doubtful state government would relate back and thereby regularize that government's earlier actions, see Cong Globe, 40th Cong, 1st Sess Appendix at 23, 28 (July 20, 1867), and in December 1867 he explained that the purpose of military reconstruction was the "modification and ratification of the illegal governments." Cong Globe, 40th Cong, 2d Sess 183 (Dec 13, 1867). 
Provisional Government. The two governments are part of the same system and the laws of the preliminary government are properly continued until they are altered by the legislation of the permanent government."223

\section{Coercion.}

That leaves the problem of coercion to ratify, a subject the Republicans said very little about. ${ }^{24}$ Republicans knew that they were imposing conditions on readmission to representation in Congress, and some of them may have believed those conditions to be an unlawful but necessary step. According to the official story, however, the conditions were lawful. In the exercise of its power to decide whether a state was entitled to representation, Congress could take into account its loyalty and the effect of its readmission on the preservation of the Union.

The answer may go deeper, however. Some indirect but still probative evidence suggests that most Republicans were not much worried about the problem of duress, even though they of course knew that their decision to keep the southerners out was bitterly criticized on both legal and political grounds. This implication comes from an instructive silence. When Congress readmitted southern states to representation it often did so on the basis of fundamental conditions. ${ }^{20}$

223 State v Jarvis, 63 NC 556, 557 (1869).

224 A typical Republican attitude was probably that of Representative Miller, who in March of 1868 argued that it was wise to condition readmission on ratification of the Fourteenth Amendment, because that way it would be unnecessary to decide whether three-fourths of the non-seceding states would be enough. See Cong Globe, 40th Cong, 2d Sess 2209 (Mar 28, 1868). Miller did not mention the possibility that a coerced ratification would be invalid. Some Democrats did make the point. See, for example, Cong Globe, 39th Cong, 2d Sess 507 (Jan 16, 1867) (Rep Dawson arguing that "[t]he imposition by the adhering States of conditions upon the seceding ... is ... in gross and flagrant violation of the principles on which the war was presumed to be waged"); id at 1333 (Feb 18, 1867) (Rep Finck) ("You go to the people of these ten States with the bayonet in one hand and your proposed constitutional amendment in the other, and ask them to make their choice.").

225 This was the conclusion of the Joint Committee's majority.

The conclusion of your committee therefore is, that the so-called Confederate States are not at present entitled to representation in the Congress of the United States; that, before allowing such representation, adequate security for future peace and safety should be required; that this can only be found in such changes of the organic law as shall [be found in the Joint Committee's proposed constitutional amendment].

Majority Report of the Joint Committee on Reconstruction, reprinted in McPherson, Reconstruction at 93 (cited in note 92 ).

226 Arkansas, first of the congressionally-reconstructed states to be readmitted, was declared entitled to representation in Congress "upon the following fundamental condition: That the constitution of Arkansas shall never be so amended or changed as to deprive any citizen or class of citizens of the United States of the right to vote who are entitled to vote by the constitution herein recognized." An Act to admit the State of Arkansas to Representation in Congress, 15 Stat 72, 72 (June 22,1868). 
Some in Congress doubted whether those conditions provided any meaningful protection, however, because there was good theoretical and doctrinal support for the proposition that Congress has no power to make an enforceable contract with a state as a condition upon admission, or at least that it has no such power with respect to political matters that are beyond congressional concern. ${ }^{227}$ But while many Republicans took seriously the possibility that their fundamental conditions would not stick, I have found none who expressed fear that the political coercion they employed would keep the constitutional amendments from sticking.

It is possible that, if asked, many legally sophisticated Republicans would have explained that what they were doing did not constitute duress under the analogous law of contract. In the nineteenth century there was good authority for the proposition that a contract was invalid because of duress only if major violence was used or threatened. Lesser threats did not invalidate a contract. ${ }^{228}$ Despite metaphors to the contrary, Congress was not demanding ratification of the Fourteenth Amendment at the point of a bayonet. It was imposing a political price on non-ratification, and political coercion may not have looked like invalidating duress to lawyers in Congress.

\section{THEORIES OF LAWFULNESS}

In deciding whether enough valid state governments validly ratified the amendments, the first point is to decide how many ratifications were needed. Part II.A considers the possibility that the unrepresented states did not count in calculating the necessary supermajor-

227 During the debate on the fundamental conditions in the Arkansas bill, some Republicans expressed doubts while others sought to assuage those doubts. Senator Roscoe Conkling of New York worried that there was no clear precedent for a condition that would stick and noted that many Radicals had expressed doubts on the issue. See Cong Globe, 40th Cong, 2d Sess 2604 (May 27, 1868). Senator Drake assured his colleagues that fundamental conditions were fine. Id at 2600 . But Lyman Trumbull thought that the issue was attended with "great difficulties." Id at 2601. Senator Morton believed that once a state was admitted to representation it could do as it pleased despite fundamental conditions, see id at 2603, and Senator Ferry announced that he would vote to readmit Arkansas despite his belief that the fundamental condition was "simply waste paper, and utterly void," id at 2608.

228 The exact magnitude of threat required to constitute duress was a matter of doubt and the doctrine seems to have been in transition. The 1839 edition of Chitty described English authority according to which only very serious threats will make a contract voidable, whereas the threat of mere battery will not. Joseph Chitty, Jr., A Practical Treatise of the Law of Contracts, Not Under Seal; and Upon the Usual Defenses to Actions Thereon 167-69 (4th American ed 1839). Chitty then described American authorities holding that duress of goods makes a contract voidable. Id. According to Theophilus Parsons in 1855 , the then-current doctrine probably was that a threat would make a contract voidable if it "was of sufficient importance to destroy the threatened party's freedom." Theophilus Parsons, 1 The Law of Contracts 321-22 (Little, Brown $2 \mathrm{~d}$ ed 1855). The important point here is that the illegality of the threat was not enough, by itself, to make a contract voidable. 
ity because of their disorganized condition. If all the states did count under Article V, then some of the southern ratifications were required, and it becomes necessary to decide whether they were effective. Part II.B considers this issue. Two objections are relevant. One is the claim that either the first-round or second-round southern governments (or possibly all of them) were not lawful state governments and hence were not capable of performing any legal act, including ratifying a constitutional amendment. Next is the claim that even if some or all of the southern legislatures were capable of acting for their states, the federal pressure designed to ensure ratification constituted the kind of duress that made the ratifications invalid.

\section{A. Disorganized States and the Denominator}

Article V requires ratification of proposed amendments "by the Legislatures of three fourths of the several States, or by Conventions in three fourths thereof, as the one or the other Mode of Ratification may be proposed by the Congress." ${ }^{229}$ As discussed above, many Republicans believed that the seceded states did not count in the denominator. A few thought that was true because those states had left the Union altogether, while a few more believed it to be true because they had ceased to exist as states, leaving their population and territory under the control of the United States. ${ }^{230}$

Much more common, possibly dominant among Republicans, was the view that although states could not leave the Union, they could be out of their practical relations with the United States, and that a state out of its practical relations did not count in the denominator. While that argument has some appeal, I find it ultimately unpersuasive.

Charles Sumner proposed a textual argument in favor of excluding the southern states, but it is not very strong. He pointed out that Article $\mathrm{V}$ refers to ratifications by legislatures, not by states, and said that if a state has no legislature then it cannot be counted among the legislatures that make up the requisite majority. ${ }^{231}$ Article V, however, does not say quite what Sumner would have liked it to say. "Threefourths" modifies "States," not legislatures. ${ }^{232}$ Thus, the question Article $\mathrm{V}$ asks is whether, as to any group of states that make up three-fourths

229 US Const Art V.

230 James G. Blaine said that very few Republicans accepted Stevens's theory of successful secession, and that the proof of this was their "absolute unwillingness to attempt an amendment to the Constitution by the ratification of three-fourths of the Loyal States only." Blaine, 2 Twenty Years at 140 (cited in note 86). Blaine in this passage did not discuss more conservative reduced denominator theories like Bingham's.

231 Cong Globe, 40th Cong, 2d Sess 878 (Jan 31, 1868).

232 US Const Art V ("Amendments ... shall be valid ... when ratified by the Legislatures of three fourths of the several States, or by Convention in three fourths thereof."). 
of the states, the legislatures of those states have ratified. Sumner's argument might have worked had Article $\mathrm{V}$ instead referred to threefourths of the legislatures of the states. If it had, one would look to the state legislatures, which could mean looking at states that had legislatures, and ask whether three-fourths had ratified. But the Constitution, for fairly obvious reasons, is interested primarily in the states and only secondarily in their legislatures, so the three-fourths requirement modifies the states.

A more powerful argument for the reduced denominator thesis comes, not from the text, but from common sense. Common sense says that a government cannot allow itself to be paralyzed by treason. As the war demonstrated, treason can wholly subvert the government of a state and temporarily expel all federal power, leaving the state with no lawful legislature and no means of holding an Article $\cdot V$ ratifying convention. If subverted states are still in the denominator, a violently disloyal minority can freeze the Article $V$ process. That process may be very important during a rebellion. There were major disputes in the North about the draft, paper money, and the use of military tribunals to try civilians. One response to a constitutional dispute is to resolve it through a constitutional amendment. For example, the country might well have benefited from an amendment that explicitly authorized the use of military tribunals to try civilians while at the same time defining more precisely the circumstances under which they could operate. As Ex parte Milligan ${ }^{233}$ demonstrates, the then-existing principles of the law of war were hardly clear enough to give much guidance. ${ }^{234}$ With all the seceded states still counting, however, such an amendment would have been impossible. According to John Bingham and those who thought as he did, it is simply inconceivable that the Constitution allows traitors so to interfere with its operation. ${ }^{235}$

Bingham's principle states a reasonable purpose to ascribe to an unclear provision. Article V, however, is pretty clear about this: threefourths of the states. If South Carolina was still a state, it counted. Moreover, implementing the concept of practical relations with the United States introduces another layer of uncertainty into Article V, which performs its function better the clearer it is. Despite what most Republicans maintained, it was an open question whether Alabama, for example, was in practical relations with the Union in 1866. While

23371 US (4 Wall) 2 (1867).

234 According to the majority in Milligan, "no usage of war could sanction a military trial" in a state where federal authority was unopposed. Id at 121. Yet the Chief Justice, speaking for himself and three others, concurred in the Court's judgment but not in its views about the operation of the law of war. "We think that Congress had power, though not exercised, to authorize the military commission which was held in Indiana." Id at 137 (Chase concurring).

235 See Cong Globe, 39th Cong, 2d Sess 501 (Jan 16, 1867). 
no senators or representatives had been admitted to Congress, neither had the state been officially declared ineligible for representation by either house, let alone Congress itself. Credentials had been referred to the Joint Committee and the applicants had not been seated, but as far as one could tell from official congressional pronouncements the whole thing was still under advisement. ${ }^{26}$ Meanwhile, the President was taking the position that the states were restored, and, as I will discuss in more detail presently, the Supreme Court was accepting cases from and remanding cases to the state courts. ${ }^{237}$ The latter in particular is a very practical relation to the Union. Practical relations is a fuzzy concept, as to which different components of the complicated federal machine can return different answers. It is not a natural for Article V. ${ }^{238}$

\section{B. Full Denominator Theories}

Although the reduced denominator theory has merits, it is also subject to doubt. While many Republicans endorsed it to varying degrees, they still did not pull the trigger and proclaim the Fourteenth Amendment ratified by three-fourths of the represented states. Instead, they waited until three-fourths of all the states had, in their view at least, agreed to the Amendment. It seems that they were not prepared to try the more aggressive theory unless they absolutely had to.

If the ex-Confederate States were in the denominator, at least some of them had to be in the numerator, because eleven was throughout this period more than one-fourth of the number of states in the Union. Any theory that proposes to count them in calculating the three-fourths must deal with the claim that their governments were bogus and inoperative, and the charge that their ratifications were coerced by President Johnson or Congress.

I will present two lines of argument concerning the ratifying governments' legal capacity. One is based on the principle of Luther, which says that when the political branches recognize a state government, that recognition is binding elsewhere. The other argument suggests that de facto state governments may take legally effective action

236 See Fleming, Civil War at 473-75 (cited in note 178).

237 In his first State of the Union message, President Johnson said that the states would be fully restored to their rightful place in the Union as soon as Congress admitted individually loyal senators and representatives; everything else already had been accomplished. Richardson, ed, 6 Messages and Papers of the Presidents at 356 (cited in note 14). The Supreme Court's conduct is described below. See Part II.B.1.b.

238 Although the Republicans controlled both houses of Congress and hence those two institutions acted in concert, it is common for the House and the Senate to be dominated by opposing parties. The constitutional system nearly ground to a halt during the Hayes-Tilden presidential contest of 1876 to 1877, mainly because the House was Democratic and the Senate Republican. See Congressional Quarterly's Guide to Congress at Appendix 94-A (cited in note 122). 
on behalf of the states they govern, despite defects in their claim to sovereign power. As to coercion, I will argue that it is doubtful whether there was any coercion that mattered, and that even if there was, the best reading of Article V is that a state's capacity to ratify is not compromised by political pressure brought to bear by the federal government.

\section{The legal capacity of the southern governments.}

a) The recognition power. For many years American courts acted on the assumption that the government in Taipei was the government of all China, although everyone knew that in fact it was not. But the Executive, the relevant political branch, recognized the Taipei regime and that was that. The courts were bound by the political branch's judgment and would not independently inquire into the question. ${ }^{239}$ What is true internationally is also true, the Supreme Court says, domestically. When the political branches decide that some political organization is the government of a state of the Union, the judiciary will act on that assumption. ${ }^{240}$ Private people and the courts thus will be bound by what the President and Congress have decided whether they

239 The Court explained its decision to defer to the executive branch:

The status of the Republic of China in our courts is a matter for determination by the Executive and is outside the competence of this Court. Accordingly, we start with the fact that the Republic and its governmental agencies enjoy a foreign sovereign's immunities to the same extent as any other country duly recognized by the United States.

National City Bank of New York v Republic of China, 348 US 356, 358 (1955).

240 The standard quotation from Luther is this passage:

Moreover, the Constitution of the United States, as far as it has provided for an emergency of this kind, and authorized the general government to interfere in the domestic concerns of a State, has treated the subject as political in its nature, and placed the power in the hands of that department.

The fourth section of the fourth article of the Constitution of the United States provides that the United States shall guarantee to every State in the Union a republican form of government, and shall protect each of them against invasion; and on the application of the legislature or of the executive (when the legislature cannot be convened) against domestic violence.

Under this article of the Constitution it rests with Congress to decide what government is the established one in a State. For as the United States guarantee to each State a republican government, Congress must necessarily decide what government is established in the State before it can determine whether it is republican or not. And when the senators and representatives of a State are admitted into the councils of the Union, the authority of the government under which they are appointed, as well as its republican character, is recognized by the proper constitutional authority. And its decision is binding on every other department of the government, and could not be questioned in a judicial tribunal. It is true that the contest in this case did not last long enough to bring the matter to this issue; and as no senators or representatives were elected under the authority of the government of which Mr. Dorr was the head, Congress was not called upon to decide the controversy. Yet the right to decide is placed there, and not in the courts. 
were right or not, just as parties are bound by judgments whether the judgments were right or not.

Participants in Reconstruction were well aware of this principle, according to which the identification of a legitimate state government was a political question to be finally decided by the political branches. Indeed, my impression is that during the Fortieth Congress, Republicans spent much more time endorsing Luther $v$ Borden than they did denouncing Dred Scott, suggesting that on balance they liked Chief Justice Taney after all. ${ }^{241}$ As announced in Luther, however, the political question doctrine is too coarse-grained to resolve the issues presented during Reconstruction, when the President and Congress were not of one mind as to the legality of different state regimes. I will develop and evaluate two variants on the doctrine, one of which gives more weight than the other to what the President does while Congress is mulling the issue.

241 Luther arose out of the remarkable events in Rhode Island in 1841 and 1842 known as Dorr's Rebellion. Rhode Island had gone through the revolutionary period without creating a written constitution. In 1841 it was still governed under the colonial charter granted by King Charles II in 1663. William M. Wiecek, The Guarantee Clause of the US Constitution 86 (Cornell 1972). The suffrage was limited to owners of $\$ 134$ worth of real property and their eldest sons and the legislature was apportioned so as to disfavor the towns that had grown in population in the first half of the nineteenth century, so that by 1840 a rural minority controlled the state government. Id at 86-87. In 1841 and 1842 proponents of a broader suffrage organized their own constitutional convention, held their own referendum on it under their own rule of suffrage, declared that they had won, and held elections for a new state government, in which their leader, Thomas W. Dorr, was chosen as Governor. Id at 91-95. After Dorr and his supporters made an unsuccessful attempt to take over the Providence arsenal in the name of their new government, the Charter Government's Governor, Samuel King, called out the militia. Id at 98-99. Governor King had the support of President John Tyler. In response to King's request for federal assistance in putting down domestic violence, Tyler had declined to use force while assuring King that if Dorr and his supporters did resort to violence, the federal authorities would support King. Id at 104-07.

Luther itself was an attempt to bring before the Supreme Court the validity of the Dorrites' attempt to exercise direct popular sovereignty. While martial law was in force in Rhode Island, Luther Borden, acting for the Charter government, had broken into the house of Martin Luther, a Dorrite. Luther, 48 US at 34-35. Luther later brought a trespass action under the federal diversity jurisdiction in which Borden justified his actions on grounds of official privilege (including martial law). Id. Luther replied that Borden was not a public officer because the lawful government at the time was Dorr's, not the government under the Charter. Id at 38. The Supreme Court held itself bound to treat the Charter government as lawful and rejected the claim for trespass. Id at $40,45-47$.

In order to understand the power of this form of the political question doctrine, it is important to see that the doctrine is not exactly one of judicial abstention. Rather, it is one of nonjudicial finality under which the courts are bound by the political branches' judgments and must decide cases in accordance with that judgment. The Court did not dismiss Luther for want of jurisdiction; it decided the case on the merits based on what it took to be the political branches' decision as to the identity of the rightful government of Rhode Island. If Congress could finally decide that the second-round governments were lawful, its decision would render legally irrelevant any judge's or citizen's view that those governments were not lawful because Congress had acted unconstitutionally in creating them. 
According to the first variant, the President's decision concerning recognition binds everyone but Congress, and Congress may override what the President has done. If it does not, the President's decision stands. If Congress decides on a different course, it then must decide whether to make its decision retroactive or to accept as final what was done under the President's dispensation. In the political catch-phrase, the President proposes and Congress disposes. ${ }^{242}$ According to the second variant, only Congress can generate a truly binding recognition of a state government. Because Congress officially blessed only Tennessee's first-round government and the ten second-round governments, for this theory to vindicate the Thirteenth Amendment it is necessary to conclude that either Congress or the second-round governments of the states involved had ratified the first-round ratifications of that amendment.

In evaluating either variant of the political question thesis, the main issue is whether recognition of state governments really is a political question in this sense. This aspect of the political question doctrine is a familiar and long-standing feature of American constitutional law, so the case for it can be stated briefly. The doctrine attaches finality to the political branches' decisions on a matter that is very much about politics, so it is natural that the rationale involves both finality and politicality.

Finality, whether of judgments or other governmental decisions, is desirable when the need for a certain and fixed answer prevails over the attraction of trying again and again to get the right answer. As Chief Justice Taney explained in Luther, it is especially important to know for certain whether a political organization is the government of a state. ${ }^{243}$ That is easy enough to see. The more interesting question concerning Luther is Taney's willingness to assign the role of answering that question to the political branches and to disclaim it for the judiciary, including his Court. ${ }^{24}$

One argument from Luther is simply about timing. In the kind of tense situation that is likely to give rise to this sort of problem, the po-

242 Formulating the point in terms of the President and Congress suppresses a complexity that needs to be addressed, at least in a footnote. In this context the President is not the only political institution other than Congress, because each House separately may face the question of a state government's validity. In principle, the question arises every time a claimant presents credentials as a senator or representative, because such claimants are elected under the auspices of or by an institution of a state government. I will not speculate on what should happen were only one House to disagree with the President, or were both Houses to do so but be unable to enact their position as law because they were unable to muster the supermajorities needed to override a veto.

24348 US at 38-39 (Grave consequences follow if an operating state government is later determined to have been unlawful.).

244 Id at 42. 
litical branches are almost certain to act first. During Dorr's rebellion, the federal officer who actually confronted the issue and made a decision was the President. President Tyler, called on by Governor King of the established Charter government, made it known that if necessary he would use the militia to support King's regime. ${ }^{245}$ For a court then to come in and interfere would be "a guarantee of anarchy, and not of order., ${ }^{246}$

A deeper reason to allocate this judgment to the political branches is that the legitimacy of a state government, although to some extent a legal question, is also a political question in the nontechnical sense of that term. It is virtually impossible to decide a dispute like this without deciding questions that are political in the sense of being normative. In part that is because the applicable standards are fuzzy, in part because the standards may be to some extent explicitly normative, and in part because individuals' convictions tend to be so strongly held. On the first point, the initial question about any putative government concerns the extent of its control of people and territory. Although that is a question of fact and easier than a lot of other questions of fact, it is by no means free from difficulty. On the second point, it is widely believed that the legitimate government of an American state must be republican, and in a republic that concept has for many people strong normative components. And last it is impossible to read the history of Reconstruction without noticing that people's views as to whether a regime was legitimate closely tracked their views as to whether it was desirable. No doubt when Republicans said that Tennessee was loyal and the other ex-Confederate States were not, they meant to say something other than that Tennessee was Republican and the others were not, but the latter fact strongly influenced views about the former issue.

Courts inevitably make normative judgments, but doing so puts a strain on the principle that they are supposed to enforce legal norms that are not necessarily their own. At some point policy so dominates an issue that having judges decide it is unnatural. The political question doctrine works in part by identifying such issues, and according to the Supreme Court the recognition of state governments is one of them.

Against all this is a simple but serious textual difficulty. Congress has the legislative and the President has the executive power, but it is the judicial power that has as its central function the final resolution of disputed questions of law and fact. If there is a political question

245 See id at 44 (In response to King's request, President Tyler took measures to call out the militia "if it should be found necessary for the general government to interfere.").

246 Id at 43.

247 Id at 42. 
principle, it is a departure from the structure in which those outside Congress, including especially the courts, are not finally bound by the legal judgments that Congress makes in the exercise of its legislative function. Moreover, there is an expressio unius problem here. In a few instances the Constitution gives some actor other than a court final decisional authority in some dispute. Each House of Congress is the "judge" of the elections, qualifications, and returns of its members, and the Senate has the sole power to "try" all impeachments. ${ }^{248}$ To use the cliché, when the Constitution's authors wanted to make Congress final on some topic, they knew how to say so.

Nonjudicial finality presents one of the hardest questions of American constitutional law, and I will not be able to resolve it to anyone's satisfaction here (nor resolve it to everyone's satisfaction anywhere). It should be enough to say that Luther states a venerable and seemingly well-established principle, the arguments for which must be taken seriously.

Because the political branches were in conflict during Reconstruction, Luther by itself does not actually provide enough of a political question doctrine to answer the questions in this Article. ${ }^{249}$ As suggested above, the doctrine can be extended in two ways. One holds that what the President does is dispositive unless Congress overrules him, and that if it does so Congress then has the choice whether to undo what the President has done. If there is a political question principle for state-government recognition, this is probably the best form of it. Both Congress and the President are political actors, and both must sometimes identify the lawful government of a state in order to perform their constitutional duties. Congress, however, is entitled to the pre-eminent role simply because it has the legislative power, which is the power to adopt norms. This point is especially strong insofar as the recognition power grows out of the Guarantee Clause. That provision imposes a duty on the United States and, by implication, grants the necessary power to carry out that duty. The Necessary and Proper Clause in turn vests Congress with authority to legislate in order to

248 See US Const Art I, $\S 5$ (Each House is the judge of its own elections.); id $\S 3$ (Senate is sole judge of impeachments.).

249 Ackerman points out that the often-quoted statement in Luther about congressional finality is a dictum, because neither house of Congress ever considered and rejected the credentials of Dorrite senators or representatives. Ackerman, 2 We the People at 443-44 n 23 (cited in note 8 ). He suggests that the case's true holding supports presidential authority, because President Tyler, unlike Congress, actually did something. See id. That is true, but it is also true that the President was exercising power specifically conferred on him by Congress in the exercise of Congress's power to carry out the Article IV guarantee against domestic violence. Luther, 48 US at 42-44. Ackerman is thus correct that the holding of Luther does not address the situation in which Congress and the President are at odds. See Ackerman, 2 We the People at 443-44. 
carry into execution all the powers vested in the United States or any of its officers or departments.

If this view is correct both amendments were ratified by valid state governments. President Johnson recognized the first-round regimes, both the four he found when he took office and the seven he helped create, and Congress never declared their ratifications invalid. It branded ten of those governments illegal, but recognized their provisional status and did not purport to delegitimize their actions with respect to the amendment. Congress then endorsed Tennessee's firstround government and the ten regimes Congress had brought into existence, thus providing valid ratifications of the Fourteenth Amendment.

The other extension of Luther simply eliminates the President and holds that only Congress may speak with final authority on this question. If that is right then we must inquire into the consequences of Congress's declaration that Tennessee's first-round government, and the other ten states' second-round governments, entitled them to representation. It is easy enough to conclude that Congress's imprimatur relates back with respect to the particular state government at issue. In identifying a lawful state government Congress is performing a judicial function, and judicial actors operate on the conceit that they declare what the law already was rather than making it anew. ${ }^{251}$

Congress's imprimatur thus validated Tennessee's ratifications of both amendments and the other ten states' ratifications of the Fourteenth Amendment. It is harder to say how to treat the other states' earlier ratifications of the Thirteenth Amendment, ratifications undertaken by governments that Congress deemed illegal but provisional. We can of course be pretty confident that the congressional majority would have wanted to ratify those ratifications too, but the tricky question is whether the recognition statutes are reasonably read to do so. I think the answer is to be found in the relationship between a provisional or temporary government and a permanent government. The latter succeeds to and perfects the former rather than simply rejecting it. $^{252}$ The natural inference, unless there is some indication to the contrary, is that the permanent government takes up where the provisional government left off, endorsing its decisions and continuing its

250 US Const, Art I ("Congress shall have Power ... To make all Laws which shall be necessary and proper for carrying into Execution the foregoing Powers.").

251 As Justice Scalia explained in a case about the retroactive effect of judicial decisions, judges make law, but "they make it as judges make $i t$, which is to say as though they were 'finding' it." James B. Beam Distilling Co v Georgia, 501 US 529, 549 (1991) (Scalia concurring).

252 State $v$ Jarvis, $63 \mathrm{NC} 556,556$ (1869) (First-round and second-round governments are parts of the same system, organized under the same authority.). 
functions. No second-round government indicated a desire to repudiate the ratification of the Thirteenth Amendment.

As Lyman Trumbull understood, Luther provides one possible way out of the difficulties that everyone confronted in the 186 \%s when seeking to identify the lawful governments of the southern states.

b) The legal capacity of de facto state governments. A recurrent theme during Reconstruction was that the southern governments were illegal, bogus, void, and apparently under Persian influence, because they were run by satraps. ${ }^{254}$ Such accusations were made about both the first-round and second-round governments. ${ }^{255}$ If a political organization is truly void it cannot perform any legal act and cannot ratify a constitutional amendment. In order for either of the amendments to have been validly ratified, some of those governments must have been capable of ratification.

On its face the ratification process appeared to be regular. In Secretary Seward's language, all but one of the ratifications came from an organization avowing itself to be, and acting as, the legislature of a state. (The exception is the Virginia legislature sitting in Alexandria, which ratified the Thirteenth Amendment; whether it was acting as the legislature of Virginia is a subject of dispute, because its practical authority was quite limited.) From the documents that were received by the Secretary of State, one could not tell the difference between the legislature of Ohio that sat at Columbus and the legislature of South Carolina that sat at Columbia.

Yet critics of both sets of southern legislatures maintained that there were differences so profound that the group in Columbus validly could bind the State of Ohio, while their counterparts in Columbia had no power to act on behalf of South Carolina. I will argue that

253 See Cong Globe, 40th Cong, 2d Sess 3630 (July 1, 1868).

254 See Cong Globe, 39th Cong, 2d Sess 252 (Jan 3,1867) (Rep Stevens stating that "this is not a Government of kings and satraps"). Reference to satrapies had become enough of a cliché that President Johnson could make jokes about it during his politically disastrous series of speeches in the run-up to the fall 1866 elections. Johnson explained how he had resisted the temptations of power offered by the Freedman's Bureau bill:

With an army, which it placed at my discretion, I could have remained at the capital of the nation, and with fifty or sixty millions of appropriations at my disposal, with the machinery to be unlocked by my own hands, with my satraps and dependants in every town and village, with the civil rights bill following on as an auxiliary, \{laughter, $\}$ and with the patronage and other appliances of the Government, I could have proclaimed myself dictator.

Andrew Johnson, On receiving the Proceedings of the Philadelphia 14th of August Convention, reprinted in McPherson, Reconstruction at 129 (cited in note 92).

255 Charles Sumner said that the first-round governments were shams and bogus and hence incapable of ratifying a constitutional amendment. Cong Globe, 39th Cong, 2d Sess 1392 (Feb 15, 1867). President Johnson returned the compliment, arguing that the second-round governments were "illegitimate and of no validity whatever." Andrew Johnson, Veto Message (July 20, 1868), reprinted in Richardson, ed, 6 Messages and Papers of the Presidents at 653 (cited in note 14). 
most of their objections raise no real difficulty. Not all can be disposed of, however, so it is necessary to confront a fundamental question: may a political organization that rules a state but that has serious defects in its claim to do so act on behalf of the state in the ratification process? My answer is yes.

One set of criticisms, mainly leveled at the first-round regimes but applicable to both, is that they were formed through means unknown to or inconsistent with state law. The conventions that organized the first-round governments performed two functions, although not all of them performed both. One function was to set back in motion the machine of loyal government that had been stopped by the rebellion. The second function was to form new state constitutions or to amend existing constitutions; this was done by all the first-round conventions except Virginia's. None of those conventions, however, was summoned in accordance with existing state law.

This is no objection. Before the war, three states had amended their constitutions through processes inconsistent with the mechanisms provided by their prior constitutions. ${ }^{256}$ In many more the legislature had called a constitutional convention even though it had no explicit power to do so. ${ }^{2.7}$ Discussing the first three examples, Judge Jameson drew what seems to me the correct conclusion: these were revolutionary acts. ${ }^{238}$ They were not violent, at least not overtly, but they were revolutionary in that they were illegal exercises of power. ${ }^{25}$

Yet all three states remained comfortably in the Union, as did the many that took the less doubtful but still troublesome step of amending their constitutions through conventions that were not called pursuant to any specific authority. It is not hard to explain this in terms familiar to American constitutional theory. The people of a state are sovereign, at least within the limits set by the Constitution of the United States, and the sovereign is superior to the law. The people

256 John Alexander Jameson, A Treatise On the Principles of American Constitutional Law and Legislation: The Constitutional Convention; Its History, Powers, and Modes of Proceeding 211-16 (Myers 1869). The three were Pennsylvania in 1789, Delaware in 1792, and Maryland in 1850. Id at 211 . In each a convention was called although some other mechanism was identified by the state constitution as the exclusive mode of amendment. Id.

257 Judge Jameson listed twenty-five such conventions when he wrote in 1869 . Id at $209 \mathrm{n} 1$. He distinguished those conventions from the three just discussed on the ground that calling a convention is a legitimate exercise of a legislature's general legislative power. Id at 209.

258 Id at 215-16.

259 In a sense the experience of those states supports Ackerman's larger thesis that Americans sometimes change their constitutions through extralegal means. Ackerman, 2 We the People at $14,22-23$ (cited in note 8). In a sense it does not, because the extralegal changes in those states resulted in new constitutions, not simply amendments to old constitutions, which could be taken to indicate that when the people exercise their ultimate sovereignty they do so in no uncertain terms. In any event this Article is concerned with the narrower question whether the Reconstruction amendments can be accounted for only as extralegal amendments. 
make constitutions and can unmake them. In doing the latter, they can use the regular forms set out in the standing constitution or such other forms as they choose.

Which means that the weightier objections will come from federal law, which must somewhere contain the conditions that a political organization must meet to qualify as the legally effective government of a state of the Union. Two suggested conditions that came up repeatedly during Reconstruction should be treated together because they have a similar structure. These are the requirements of loyalty and republican form.

Article VI indicates that a state government, in order to qualify as such, must through its law recognize the supremacy of federal law. ${ }^{201}$ Its officers must in general be bound by the Article VI oath. ${ }^{262}$ Hence whatever else they were, the organizations that sent senators to Richmond were not governments of United States. Article VI imposes a necessary condition for loyalty: a state government must represent itself as such in its law. The Confederate governments did not.

But is that a sufficient condition? The most fundamental objection Republicans raised to the first-round governments was that they were not loyal. ${ }^{263}$ They were nothing but Confederate governments in disguise. ${ }^{264}$ Many Republicans believed that the state institutions, like the people who ran them, had falsely asserted that they adhered to a Union they intended to destroy. It was as if in 1863 the Confederate legislatures had come up with a scheme to pretend to rejoin the Union, send senators to Washington, and paralyze the opposition politically.

260 The issue came up during the debates on fundamental conditions in the readmission of the southern states. Discussing the effectiveness of entrenching provisions in state constitutions, Senator Morton noted that the right of the people to change their constitution is inalienable, and several states had engaged in constitutional change contrary to prior limitations on the amendment process. Cong Globe, 40th Cong, 2d Sess 2742-43 (June 1, 1868). Senator Edmunds interjected that such changes were an exercise of the "right of revolution," but he did not deny that the people retained that right with respect to the state constitutions. Id at 2743.

261 US Const, Art VI ("This Constitution and, the Laws of the United States ... shall be the supreme Law of the Land.").

262 Id ("[T]he Members of the several State Legislatures, and all executive and judicial Officers ... of the several States, shall be bound by Oath or Affirmation, to support this Constitution."). The qualifier "in general" reflects the point that an entire state would not be paralyzed were it discovered that a small number of officers, contrary to the state's law and policy, had failed to subscribe to the requisite oath or affirmation.

263 See, for example, Cong Globe, 39th Cong, 2d Sess 159 (Dec 17, 1866) (Sen Trumbull); id at 626 (Jan 21, 1867) (Rep Higby); id at 814 (Jan 28,1867) (Rep Collum); id at 1100 (Feb 8, 1867) (Rep Hotchkiss).

264 In January 1867, for example, Representative Broomall complained that southern loyalists were being ruled by "organizations as thoroughly rebel as those which formed constituent parts of the late confederacy." Id at 349 (Jan 8, 1867). About ten days later Representative Scofield charged that those governments were "only the confederate governments revived." Id at 597 (Jan 19, 1867). 
That would be a serious problem, and one would hope that the Constitution provides some remedy for it. Very likely there is such a remedy, but it does not consist of a self-executing rule that disloyal governments are legally ineffective even if they comply with the forms of Article VI. First, the Constitution does not indicate this explicitly. Second, once we move beyond the requirements of Article VI, the concept of loyalty becomes both vague and difficult to implement. Consider the Virginia government that convened in the late fall of 1865 . No doubt many of its legislators and the voters who elected them were unrepentant Confederates. A few may have been repentant Confederates. Many were probably Confederates who had given up on secession and were prepared, however grudgingly, to try to make the Union thing work. Whatever the legislators may have felt, their Governor was a rock-solid Union man. To implement the extended notion of loyalty, it would be necessary to have at least a rough idea of how much tincture of treason it takes to render a whole institution incapable. It would then be necessary to know at least something of the evil that lurks in the hearts of state officers, because by hypothesis they will have sworn or affirmed to support the Constitution. It would be very troublesome to conclude that the Constitution had a norm this squishy on a question this fundamental.

To reject disloyalty as a criterion of state governmental authority, however, is not to say that the Constitution provides no response to ostensibly loyal state governments that are run by traitors. The United States has power to put down rebellion, and Congress has power to legislate to that end. ${ }^{2.5}$ And while it would be extraordinary for Congress to legislate that a seemingly regular state government was without legal power because it was in fact an instrument of treason, rebellion presents extraordinary problems. When it occurs, Congress may take the extreme step of suspending the writ of habeas corpus, thereby temporarily withdrawing natural liberty itself from judicial protection and placing it in the hands of the executive authority. ${ }^{266}$ Suspending a state government is also an extreme step, but as the Civil War demonstrates the Constitution can confront some pretty extreme times.

While this approach does not dispose of the difficulties in judging the loyalty of state governments, it does largely remove them from the legal realm. Of course, Congress's power to invalidate a state govern-

265 See, for example, Prize Cases, 67 US (2 Black) 635, 666-67 (1863) (While civil wars are not formally declared, the actions of the Confederate States created a state of war nonetheless.).

266 "The Privilege of the Writ of Habeas Corpus shall not be suspended, unless when in Cases of Rebellion or Invasion the public Safety may require it." US Const, Art I, $\S 9, \mathrm{cl} 2$. There is no expressio unius argument here, because the Suspension Clause is not the source of the authority to suspend the writ; it is a limitation on that authority, the existence of which is assumed. The Constitution takes it for granted that the United States may suppress rebellion. 
ment in order to suppress rebellion is subject to some constitutional limits, as is its power to charter national banks. ${ }^{267}$ In order to exercise the former authority, Congress must have good grounds to believe that a state government is an instrument of treason. But whether Congress reasonably could reach a conclusion and whether the conclusion is true are very different questions, as constitutional doctrine has demonstrated ever since $M^{\prime}$ 'Culloch $v$ Maryland. ${ }^{268}$ And while it is dangerous to give any institution the power to overturn a state government, it is dangerous to give any institution the power to suspend the writ of habeas corpus or indeed to declare war.

Similar reasoning applies to the objection that the first-round governments were not republican in form. Many proponents of congressional reconstruction maintained that some or all of those governments were unrepublican because they disenfranchised so many citizens. ${ }^{269}$ Whatever one makes of that argument, the question need not be resolved in order to decide whether the Guarantee Clause invalidated the first-round governments. As the Supreme Court subsequently held, that provision is not self-executing.

The Clause is formulated, not as a limitation on the states like the Contracts Clause, but as a duty of the United States. ${ }^{271}$ In addition to the verbal distinction, the imposition of a duty with a corresponding implied power suggests discretion in carrying out the duty. The reason the Constitution would tell Congress to do something rather than simply doing it directly is that the best way to guarantee a republican form of government is not always obvious. In particular, it is not obvious that invalidation of official acts is a good idea. As Chief Justice Taney explained in Luther, to say that a government was unlawful has immense and damaging consequences, usually much more so than saying that some particular statute is invalid. ${ }^{272}$ So Congress may remedy a

267 See M'Culloch v Maryland,17 US (4 Wheat) 316,421 (1819) (holding that Congress may utilize all means which are appropriate to achieve a legitimate end and which "consist with the letter and spirit of the constitution").

268 Id at 413-19 (Congress has discretion in deciding whether a means is necessary and proper to carry out a constitutional end.).

269 Representative Broomall presented a sophisticated form of this argument, one designed to deal with the obvious objection that in some states most of the adult citizens could not vote. He maintained that a republic was a government in which all citizens have suffrage either directly or through someone who represents them because of "legal, social, or family relations." See Cong Globe, 39th Cong, 2d Sess 350-51 (Jan 8, 1867). Although slaves had been part of their masters' households, freed people were not and had no one to represent them. They were therefore entitled to vote, and a state in which they could not vote was unrepublican. Id.

270 See Pacific States Telephone and Telegraph Co v Oregon, 223 US 118 (1912) (Enforcement of Guarantee Clause is with Congress, not the judiciary.).

271 "The United States shall guarantee to every State in this Union a Republican Form of Government." US Const Art IV, §4.

27248 US at 38-39 (holding, since the decision whether the charter government had legal existence could lead to serious results, the Court must "examine very carefully its own powers 
failure of republican form in a variety of ways that need not include completely disrupting the rule of law in a state.

As to disloyalty and unrepublican form, the proper question thus is not about the state governments themselves but about what Congress did. In particular, the question is whether Congress retrospectively invalidated the acts of the ten state governments that the first Military Reconstruction Act declared to be illegal. It did not. The Act went on to recognize those governments as provisional and to assume that they would continue to operate on a provisional basis. ${ }^{273}$ And of course it is difficult to believe that anyone who supported military reconstruction meant to reach out and undo the southern ratifications of the Thirteenth Amendment.

From the standpoint of constitutional architecture, the preceding difficulties are small beer compared to the central fact about Reconstruction: it was almost all federally driven. Of the twenty-one reconstructed governments, twenty were in substantial measure the result of federal action. Three first-round governments were organized pursuant to President Lincoln's proclamation of December 8, 1863, ${ }^{274}$ and seven under President Johnson's plan, typified by his North Carolina proclamation in May $18655^{275}$ All ten second-round governments were organized under the Reconstruction Acts. ${ }^{276}$ Only Virginia's first-round government was the product of genuine self-reconstruction.

The federal role was unusual and was highly controversial at the time, and its legitimacy is one of the central questions in this Article. This is a subtle problem, one that requires some careful analysis simply to see what the questions are. Much ink was spilled as to whether the President and Congress were ${ }_{\mathrm{c}}$ acting within the powers granted them by the Constitution. Opponents of presidential action maintained that the Commander in Chief was supposed to put down rebellion by military force but had no role in reviving civil government. ${ }^{27}$ Opponents of congressional action maintained either that Congress had no power that ever could be used to rebuild a state government, or that if it had such a power in the Guaranty Clause the conditions for its use had not been fulfilled. ${ }^{27}$

before it undertakes to exercise jurisdiction").

273 See 14 Stat 428, 429 (Mar 2,1867) ("[A]ny civil governments which may exist [within the ex-Confederate States] shall be deemed provisional only.").

274 See Richardson, ed, 6 Messages and Papers of the Presidents at 213-15 (cited in note 14).

275 See id at 312-14.

276 See 14 Stat 428 (Mar 2, 1867) (first Military Reconstruction Act); 15 Stat 2 (Mar 23, 1867) (first supplementary Military Reconstruction Act).

277 See, for example, McPherson, Reconstruction at 84-85 (cited in note 92) (Report of Joint Committee arguing that President Johnson exceeded his powers in creating new state governments).

278 See, for example, id at 97 (Report of Joint Committee minority, arguing that Congress 
In this form the argument about federal power is irrelevant. An act by a federal officer or institution in excess of constitutional power is a legal nullity; that is a first principle of the Constitution. ${ }^{279}$ Hence if Congress or the President acted ultra vires, their acts could have no legal effect, and in particular could not confer sovereign authority on a state government. State governments, however, derive their sovereign power from the people, not from any act of President or Congress. Because the states do not rely on federal power, the question whether federal power was available is beside the point.

This is not to say that federal involvement in state formation is irrelevant, only that the question is not whether the federal actors were within their legal authority. Rather, the question is whether the federal action violated an implicit affirmative limitation in favor of state autonomy, and if it did whether the resulting state regimes were legally effective nevertheless. Congressional reconstruction involved a major federal interference with state autonomy. Although the Reconstruction Acts do not mention bayonets, their implication is clear enough. State governments organized by the electorates described in the legislation would be recognized as legitimate, which meant that those governments would be entitled to federal protection against domestic violence under Article IV. ${ }^{280}$ Attempts to resist the new regimes' authority on the ground that the earlier governments were legitimate and these were usurpations would get the treatment President Tyler told Governor King he would give to Governor-pretender Dorr. ${ }^{281}$ Only this time it would be the insurgents who would get federal support. ${ }^{282}$ Moreover, the Reconstruction Acts promised represen-

has no power to interfere with a state's choice of government). One of the primary functions of the destroyed governments thesis was to support congressional action under the Guaranty Clause. The argument was that if a state has no government at all then Congress's obligation to guarantee a republican form of government entails creating a government that will be republican.

279 See, for example, Marbury v Madison, 5 US (1 Cranch) 137, 176 (1803) ("[A]n act of the legislature, repugnant to the constitution, is void."). "The sanction of nullity is pervasive in the whole theory of American public law." Henry M. Hart, Jr. and Albert M. Sacks, The Legal Process: Basic Problems in the Making and Application of Law 154 (Foundation 1994) (William N. Eskridge, Jr. and Philip P. Frickey, eds).

280 See US Const Art IV, $\$ 4$ ("The United States shall ... protect [every state in this Union] against Invasion.").

281 See Luther, 48 US at 44.

282 I focus on congressional reconstruction because the case against what the Presidents did is much weaker. For one thing, their interference with state suffrage rules was on stronger ground because it was plausibly tied to suppression of insurrection. Lincoln was dealing with still-flagrant rebellion and Johnson with a rebellion that had just been put down. Keeping the disloyal out of state governments that were being reorganized was a reasonable way to fight the rebellion, and the loyalty oaths were designed to do that. Moreover, the actual influence of presidential commands on the resulting state regimes was more limited than those of Congress. President Lincoln in his proclamation said nothing about suffrage rules under the new constitutions, see Richardson, ed, 6 Messages and Papers of the Presidents at 213-15 (cited in note 14), 
tation in Congress to states in which new governments were established, thus creating a possibly unlawful incentive to accept a new constitution.

Whether that action really violated constitutional principles of state autonomy is a hard question. If Shellabarger was right and the states were without lawful governments, then what Congress did is easy to defend. ${ }^{284}$ Congress was obliged to help the states get a republican form of government, and in decreeing race-blind suffrage it was not displacing state law because there was no state law. Moreover, anyone who believes that Congress or the President legitimately could have recognized Governor Dorr should believe that the Reconstruction Acts were valid. In South Carolina as in Rhode Island a new, broader electorate claimed legitimacy through a referendum carried on outside of ordinary state law.

It is not necessary to resolve these deep questions, because it is easier to resolve an even deeper question: what does it take for a state government, whatever its flaws, to take legally effective action on behalf of the state? I will suggest that a de facto government can act for the state, and sometimes even limited de facto authority will be enough. (The qualification concerns the Virginia government at Alexandria.)

A standard principle of international law is that a de facto government can bind a state internationally, even though that government's authority is usurped. As John Bassett Moore wrote in 1906, "The state is bound by engagements entered into by governments that have ceased to exist; the restored government is generally liable for the acts of the usurper." ${ }^{285}$ Debts contracted and treaties entered into

and President Johnson explicitly made the point that once the conventions had met the question of suffrage would be in the hands of the states, where it had always been, see, for example, id at 313 (North Carolina's proclamation). They did not try to reshape the states' electorates over the long term, so the federal impress on the resulting state governments was much fainter.

283 The issue of federal political coercion through denial of representation in Congress thus enters into this problem twice. The second-round regimes were created in response to that stick (or carrot, if Congress was justified in what it did), and they ratified in response to the same incentive.

284 See Cong Globe, 39th Cong, 1st Sess 142 (Jan 8, 1866).

285 John Bassett Moore, 1 A Digest of International Law 249 (GPO 1906). Moore went on to quote an 1827 letter from Secretary of State Henry Clay to the American Minister to France, laying out the United States's position as to the restored royal government's responsibility for the depredations of Napoleon:

It is not necessary to discuss the question of usurpation which is put forward. It is sufficient for us that those acts and depredations proceeded from the actual Government of France; and that the responsibility of France to make reparations for wrongs committed under the authority of any form of government which she may have adopted, or to which she may have submitted, from time to time, can not be contested.

Id at 249-50. Moore then quoted a letter of the same tenor from Clay's successor, Martin van Buren. Id at 250. 
by the regime with practical control bind future governments, including future governments that come to power denying that the earlier regime was lawful. During the nineteenth century, the Supreme Court's favorite illustration of this principle seems to have been the international treatment of the English Commonwealth under Cromwell. The crowned heads of Europe were not much enthused about a soldier who had put a King to death, but they maintained relations with Cromwell's government, and the restored monarchy claimed Cromwell's acquisitions and accepted the responsibilities he had undertaken.

One especially striking application of the underlying principle was found in the domestic public law of Great Britain as described by Blackstone. Discussing the treason statute, Blackstone explained:

[t]he king here intended is the king in possession, without any respect to his title; for it is held, that a king de facto and not de jure, or, in other words, an usurper that hath got possession of the throne, is a king within the meaning of the statute: as there is a temporary allegiance due to him, for his administration of the government and temporary protection of the public. ${ }^{287}$

Kings seem to think that killing kings, even usurpers, should be discouraged.

Chief Justice William Howard Taft, sitting as an international arbitrator, quoted Moore and applied this principle in an arbitration between Great Britain and Costa Rica for claims arising from the de facto government of Frederico Tinoco in Costa Rica. See Arbitration Between Great Britain and Costa Rica, Opinion and Award of William H. Taft, Sole Arbitrator (Oct 18, 1923), reprinted in Judicial Decisions Involving Questions of International Law, 18 Am J Int L 147, 14951 (1924).

286 See, for example, Thorington $v$ Smith, 75 US (8 Wall) 1, 8 (1869):

Another example may be found in the government of England under the Commonwealth, first by Parliament, and afterwards by Cromwell as Protector. It was not, in the contemplation of law, a government de jure, but it was a government de facto in the most absolute sense. It incurred obligations and made conquests which remained the obligations and conquests of England after the restoration.

See also Williams v Bruffy, 96 US (6 Otto) 176, 185 (1878) (Treaties and contracts of governments like Cromwell's are usually enforced and its acquisitions are retained.).

287 William Blackstone, 4 Commentaries * 77. Blackstone went on to give an example.

[A]nd, therefore, treasons committed against Henry VI [grandson of Henry Bolingbroke who usurped the throne from Richard II and became Henry IV] were punished under Edward IV [whose ancestor had the rightful claim to the throne after Richard II's death], though all the line of Lancaster [Henry IV-Henry VI] had been previously declared usurpers by act of parliament. But the most rightful heir of the crown, or king de jure and not de facto, who hath never had plenary possession of the throne, as was the case of the house of York during the three reigns of the line of Lancaster, is not a king within this statute, against whom treasons may be committed. 
The logic of the de facto principle has not been lost on the Supreme Court of the United States. One obscure but very instructive example is a remarkable Waite Court case, Phillips $v$ Payne. ${ }^{288}$ In 1789 Virginia ceded to the United States some territory on the Potomac that would form part of the District of Columbia. ${ }^{289}$ Virginia's donation became the District's County of Alexandria (Maryland's contribution became the County of Washington). ${ }^{291}$ In July 1846 Congress passed an act authorizing a vote by the residents of Alexandria County to determine whether the County should be ceded back to Virginia, and it was. ${ }^{291}$ Almost thirty years later an Alexandria taxpayer challenged the retrocession, arguing that Congress had no power to let go of any of the District, and that therefore Virginia had no power to levy taxes in Alexandria. ${ }^{292}$

The Court did not reach the merits of retrocession. Instead it rejected the taxpayer's claim because "[t]he State of Virginia is de facto in possession of the territory in question." ${ }^{\text {,293 }}$ Both Virginia and the United States were satisfied with the transaction, and if the taxpayer's argument were accepted

serious consequences would follow. ... [T] axes have been illegally assessed and collected; the election of public officers, and the payment of their salaries, were without warrant of law; public accounts have been improperly settled; all sentences, judgments, and decrees of the courts were nullities, and those who carried them into execution are liable civilly, and perhaps criminally, according to the nature of what they have severally done. ${ }^{294}$

The parade of horribles was turned back, however, because a "government de facto, in firm possession of any country, is clothed, while it exists, with the same rights, powers, and duties, both at home and abroad, as a government de jure."

\author{
28892 US 130 (1875). \\ 289 Id at 131. \\ 290 Id. \\ 291 Id. \\ 292 Id at 131-32. \\ 293 Id at 133. \\ 294 Id. \\ 295 Id. Justice Swayne elaborated the point. A de facto government
}

may send ambassadors and make treaties. Such treaties bind the nation and descend in full force upon any succeeding government that may be established. The assailants of a king de facto in England are liable to be punished for treason.... The legislative and judicial authorities called into existence may proceed as if the prior government had not been displaced. All municipal functions may be performed without regard to the origin of the new policy. Cromwell's ambassadors were received everywhere. Hale accepted from him the place of a judge of the common pleas. After the Restoration, Charles II made him Chief Baron of the Exchequer, and subsequently Chief Justice of the King's Bench. The Code Napoleon was the work of a ruler whose government arose amid the ruins of a revolution, 
Maybe when he wrote that Justice Swayne, a Lincoln appointee, had been thinking about his Court's conduct during the great crisis of the Union and its aftermath. Of most interest here is the fact that the Supreme Court of the United States, apparently without missing a beat, treated the first-round and then the second-round governments as if they were legally effective. ${ }^{226}$ When the war broke out, the Supreme Court placed cases from the southern circuits and the southern state courts on hold. They were deferred, but not dropped from the docket. Then in February 1866 the Court restored those cases to the docket and called them in the regular order.

One such case was McGee v Mathis, ${ }^{299}$ which came up on a writ of error to the pre-secession Supreme Court of Arkansas. ${ }^{298}$ It was held on the docket, then finally argued in 1867. The Supreme Court reversed and remanded the case with instructions to enter a decree in conformity with its opinion. ${ }^{299}$ When the remand order was entered, the Supreme Court of Arkansas was that of the Lincoln government. Another example of this configuration came shortly thereafter in Locke $v$ New Orleans. ${ }^{300}$ Locke affirmed a judgment entered by the pre-secession Supreme Court of Louisiana. When Locke was decided Louisiana was under its first-round, presidentially-reconstructed government. Those cases came from the pre-secession state judiciaries and the Court sent them back to a court of the first-round governments.

A slightly more complicated series of events arose with respect to a case between Reuben White and Elijah Cannon in Louisiana. In January 1861 the Louisiana Supreme Court decided a lawsuit between them. ${ }^{302} \mathrm{~A}$ writ of error to the Louisiana court was filed with the Supreme Court of the United States on November 20, 1866. ${ }^{303}$ A motion to dismiss was argued on February 7,1868 , and the merits were argued

and was subsequently overthrown. The governments of both these rulers were doubtless regarded by the other governments of Europe as only de facto.

Id at 133-34.

296 Senator Reverdy Johnson of Maryland, an eminent member of the Supreme Court's bar, noticed what the Court was doing and discussed it during the debates on the first Military Reconstruction Act. He maintained that the executive and judicial branches had recognized the first-round governments, pointing out that the Court was "entertaining appeals and writs of error" from the superior courts of the southern states. Cong Globe, 39th Cong, 2d Sess 1379 (Feb $15,1867)$.

29771 US (4 Wall) 143 (1866).

298 Id at 144.

299 Id at 158.

30071 US (4 Wall) 172 (1866).

301 See New Orleans $v$ Locke, 14 La Ann 854, 854 (1859) (holding that there is no provision of law fixing the period of prescription of a tax bill at five years).

302 Cannon v White, 16 La Ann 85 (1861).

303 Dockets of the Supreme Court of the United States: August 9, 1860-October 29, 1872, No 5823 (National Archives 1954). 
on March 26 of that year. ${ }^{304}$ Less than two weeks later, on April 6, the Supreme Court affirmed the judgment below. ${ }^{305}$ That case came either from a pre-secession court or a first round court, depending on whether one looks at the decision or the writ of error, and was sent back to a first-round state court. ${ }^{306}$

In similar fashion the Court was prepared to take a case from a first-round state court and remand to its second-round successor. It did that in Steamboat Belfast $v$ Boon \& $\mathrm{Co}^{307}$ That case was decided by the Supreme Court of Alabama under the Johnson government in 1867 , after that government had been determined by Congress to be illegal and provisional only. ${ }^{308}$ On October 29,1867 , a writ of error was filed with the Supreme Court. ${ }^{309}$ The case was argued on March 23, 1869, after Alabama's new constitution had gone into effect and the state had been restored to representation..$^{310}$ On April 12, 1869, the judgment of the first-round Alabama court was reversed and the case remanded to the second-round court with directions to dismiss.

Not only was the Court prepared to remand to first-round or second-round state courts, it apparently was prepared to remand without knowing who would receive its mandate. Paul $v$ Virginia $^{312}$ involved a statute regulating insurance corporations that was passed in February 1866 by the same legislature that had adopted Virginia's Black Code. ${ }^{313}$ Paul, agent of a New York insurance firm that had been unable to obtain a Virginia license, was prosecuted for conducting business in Virginia without the license. ${ }^{314} \mathrm{He}$ was convicted in a Virginia Circuit Court, and the Supreme Court of Appeals of Virginia, organized under the Alexandria Constitution of 1864 , affirmed the conviction. A

304 Id.

305 White $v$ Cannon, 73 US (6 Wall) 443 (1867). Perhaps the most interesting feature of the case is the fact that the decision under review was rendered a few days after Louisiana's ordinance of secession was adopted. Justice Field, speaking for the Court, said that this was not important because "[t]hat ordinance was an absolute nullity, and of itself alone, neither affected the jurisdiction of that court [the Supreme Court of Louisiana] or its relation to the appellate power of this court." Id at 450 .

306 Louisiana's second-round constitution was ratified, and officers under it were elected, on April 16 and 17, 1868. Taylor, Louisiana Reconstructed at 158 (cited in note 41).

30741 Ala 50 (1867).

308 See 14 Stat $428,428(\operatorname{Mar} 2,1867)$ (" $[\mathrm{N}]$ o legal State government [ ] . . now exists in the rebel State[ ] of ... Alabama.").

309 Dockets of the Supreme Court of the United States at No 5980 (cited in note 303).

310 Id; Fleming, Civil War at 550-52 (cited in note 178).

311 Dockets of the Supreme Court of the United States at No 5980 (cited in note 303). Woodruff $v$ Parham, 75 US (8 Wall) 123,123-24 (1868), has a similar procedural history. A writ of error to the Supreme Court of Alabama was filed on November 6, 1867. See Dockets of the Supreme Court of the United States at No 5989. The case was argued on October 12 and 13, 1869, and the judgment was affirmed on November 8 of that year. Id.

31275 US (8 Wall) 168 (1870).

313 See Fairman, 6 History of the Supreme Court at 110-15 (cited in note 137).

314 See Paul, 75 US (8 Wall) at 169. 
writ of error was filed on November 16, 1867, after that government had been declared illegal but while it was still in existence, and the case was argued over several days in October $18699^{315}$ The Court affirmed the judgment below on November 1, 1869, after the secondround government had been organized but before Virginia's new Supreme Court of Appeals had met for the first time and before Congress had declared that Virginia had a republican form of government that entitled it to representation in the federal legislature. ${ }^{316}$ The Court thus had remanded the case to whatever tribunal was sitting as the highest court of Virginia.

None of the gyrations in state government, and none of the doubts about the legality of state governments, seemed to bother the Court in its practical operations. In an opinion on circuit, Chief Justice Chase allowed himself to express a little puzzlement as to how the Pierpont government of Virginia, which had been able to consent to the formation of West Virginia, had become provisional. ${ }^{317}$ Those doubts, and whatever doubts other justices may have had about what was going on, do not seem to have mattered when it came to deciding cases. Instead, the Court accepted writs of error from whatever state court seemed to be in charge, and remanded cases to whatever state court seemed to be in charge.

From the Court's actions we cannot, of course, be sure about the Justices' thinking. Maybe a majority believed that the first-round governments were genuinely lawful and that the courts were bound under Luther by Congress's endorsement of the second-round governments. We have a window into the Justices' thinking, however, because of Texas $v$ White. ${ }^{318}$ White was brought on behalf of Texas in the Court's original jurisdiction. It was a suit in equity to recover United States government bonds issued to the State of Texas and sold to private persons by the Confederate state government. Before proceeding to the merits, Chief Justice Chase sought to assure himself that Texas was still one of the United States and that it had a government that could prosecute the suit. In discussing the first issue the Court made its most famous statement about the nature of the Union, rejecting both Calhounism and Stevens-thought:

315 Dockets of the Supreme Court of the United States at No 6000 (cited in note 303).

316 Id. Paul had challenged his conviction on constitutional grounds. The Court apparently had no problem with affirming a first-round state court's decision on such an issue. Paul, 75 US (8 Wall) at 177,185 .

317 "It is unnecessary to discuss here the question whether the government of Virginia, which seems to have been not provisional, but permanent, when transferred from Alexandria to Richmond, became provisional under the subsequent legislation of congress ...." Griffin's Case, $11 \mathrm{~F}$ Cas 7,27 (CCD Va 1869).

31874 US ( 7 Wall) 700 (1868). 
Not only, therefore, can there be no loss of separate and independent autonomy to the states, through their union under the Constitution, but it may not unreasonably be said that the preservation of the states, and the maintenance of their governments, are as much within the design and care of the Constitution as the preservation of the Union and the maintenance of the National government. The Constitution, in all its provisions, looks to an indestructible Union, composed of indestructible States. ${ }^{319}$

That was good, moderate Republican orthodoxy, but the identity of Texas's government was another question: "But in order to the exercise, by a State, of the right to sue in this court, there needs to be a State government, competent to represent the State in its relations with the National government, so far at least as the institution and prosecution of a suit is concerned. ${ }^{, 320}$ When the case was decided Texas was still under military rule pursuant to the Reconstruction Acts, with a Governor appointed by the commanding general to replace one elected under the first-round constitution, who had replaced the provisional governor appointed by President Johnson. ${ }^{321}$ Chief Justice Chase recognized that there were legal difficulties with all three, but maintained that the Court did not have to address those difficulties. After describing the presidential reconstruction that produced the first two Governors, he went on: "Whether the action then taken was, in all respects, warranted by the Constitution, it is not now necessary to determine." ${ }^{322}$ The same was true for congressional reconstruction. "Nothing in the case before us requires the court to pronounce judgment upon the constitutionality of any particular provision of these acts."

Which leaves us to wonder how any of the three Governors could have taken a legally effective act, if the constitutionality of their accession to power was still an open question. The answer seems to have been their de facto authority. Right after disclaiming any need to pronounce on the Reconstruction Acts, the Chief Justice pointed out that in those acts "the governments, which had been established and had been in actual operation under executive direction, were recognized by Congress as provisional, as existing, and as capable of continu-

319 Id at 725.

320 Id at 726-27.

321 President Johnson appointed A.J. Hamilton provisional governor of Texas in June 1865, id at 707 , and J.W. Throckmorton was subsequently elected Governor of the first-round government, id at 708. Throckmorton authorized institution of the suit on behalf of Texas. Id at 708-09. General Sheridan deposed Throckmorton and appointed Elisha M. Pease pursuant to the Reconstruction Acts, and Pease renewed the appointment of counsel to maintain the suit. Id at 709. 
ance. ${ }^{, 32}$ Then came the conclusion, which again disclaimed definite inquiry into legality.

Each of the three [Governors] exercised executive functions and actually represented the State in the executive department. In the case before us each has given his sanction to the prosecution of the suit, and we find no difficulty, without investigating the legal title of either to the executive office, in holding that the sanction thus given sufficiently warranted the action of the solicitor and counsel in behalf of the State. ${ }^{325}$

The exercise of actual power made it unnecessary to investigate legal title.

If any reader of Texas $v$ White had lingering doubts about the strength of the de facto principle, the Chief Justice presently dispelled them. After resolving the jurisdictional question, he turned to the merits, and the first issue on the merits was whether the bonds had lawfully been sold by the Confederate state government of Texas. The answer was that they had not, but that answer did not follow because the Confederate Texas government was wholly without legal authority, even though it was of course quite illegal. The de facto principle is strong, and but for the Constitution it would have made legally effective everything done by the rebel government of Texas. ${ }^{326}$ It is not stronger than the Constitution, however, and the Court's compromise position was that acts of the rebel government were effective insofar as they governed private rights, but acts in support of the rebellion were in general invalid and void.

Chief Justice Chase thought pretty highly of the legal effectiveness of de facto governments.

He seems not to have been alone. Especially instructive is the conduct in this regard of the people who organized the second-round regimes. No one had a greater stake in the principle that the firstround governments were not de jure. Of course, the people of a state

324 Id.

325 Id at $731-32$.

326 The Chief Justice said that the rebel legislature

cannot be regarded, therefore, in the courts of the United States, as a lawful legislature, or its acts as lawful acts. And, yet, it is an historical fact that the government of Texas, then in full control of the State, was its only actual government; and certainly if Texas had been a separate State, and not one of the United States, the new government, having displaced the regular authority, and having established itself in the customary seats of power, and in the exercise of the ordinary functions of administration, would have constituted, in the strictest sense of the words, a de facto government, and its acts, during the period of its existence as such, would be effectual, and, in almost all respects, valid. And, to some extent, this is true of the actual government of Texas, though unlawful and revolutionary, as to the United States. 
may replace their government at their pleasure, so in ordinary circumstances the validity of a new state constitution does not rest on the invalidity of the preceding one; usually the process that produced the new constitution will have been set in motion under the old one. But the creation of the second-round regimes was not altogether spontaneous with the people of the states involved. It was prompted by Congress and conducted by federal officials under new rules of suffrage. The best justification for this extraordinary federal involvement was the claim that Congress was operating in a vacuum of state law, the states' earlier political laws having been abrogated. If that was true the first-round regimes were of doubtful validity.

Despite this strong incentive to act in accordance with the official pronouncement of the Reconstruction Acts, none of the new regimes adopted a broad repudiation of what had gone before. In general they recognized some legal force to the acts of the first-round governments, while sometimes explicitly rejecting those regimes' claims to full legitimacy.

The Texas constitution of 1869 is particularly interesting because it dealt with the continuity issue in some detail and had a sliding scale of legitimacy. Section 33 of Title XII began by branding the ordinance of secession and everything based on it "null and void from the beginning. ${ }^{328}$ As for the rebel legislature, it "had no constitutional authority to make laws binding upon the people of the State of Texas,",329 but the reconstructed state authorities were not to be inhibited from

respecting and enforcing such rules and regulations as were prescribed by the said legislatures which were not in violation of the Constitution and laws of the United States, or in aid of the rebellion against the United States, or prejudicial to the citizens of this State who were loyal to the United States, and which were actually in force or observed in Texas during the above period of time.

Continuing to ascend the hierarchy of legitimacy, the Texas constitution then came to the first-round legislature, which was neither null and void from the outset nor lacking in constitutional authority, but

provisional only, and its acts are to be respected only so far as they were not in violation of the Constitution and laws of the United States, or were not intended to reward those who partici-

328 Texas Const of 1868 Art XII, $\S 33$ (superseded 1876).

329 Id.

330 Id. Reminding the reader of the point about the reason for recognizing de facto governments, the provision continues "nor to affect, prejudicially, private rights which may have grown up under such rules and regulations." Id. 
pated in the late rebellion; or to discriminate between citizens on account of race or color; or to operate prejudicially to any class of citizens. ${ }^{331}$

That far, however, they were to be respected. And when it came to the cash nexus, the provisional legislature was recognized as having legitimately borrowed money for Texas whereas the rebel legislature was not. ${ }^{332}$

Louisiana also evinced some hesitation about its Lincoln-inspired regime, although more subtly. Its 1868 constitution explicitly superseded "the constitution adopted in 1864 , and all previous constitutions in the State of Louisiana. ${ }^{333}$ The Louisiana constitution of 1852, by contrast, had superseded only its immediate predecessor, the constitution of 1845 , without referring to any prior constitutions. ${ }^{344}$ Maybe the drafters in 1868 had doubts about the efficacy of the provision in the 1864 constitution that had superseded the 1852 document. ${ }^{335}$ Those drafters do seem to have believed that the acts of the first-round legislature had at least de facto effect, because they declared valid the laws in force when the 1868 constitution was adopted; putting that as a declaration and referring to laws in force indicates that, whatever their provenance, those laws were effective. ${ }^{336}$ Georgia too affirmed its legal continuity while casting a sidelong glance at the troubles through which it had passed, endorsing with stated exceptions "all acts passed by any legislative body, sitting in this State as such, since the 19th day of January, 1861.",33

The other second-round constitutions that dealt explicitly with legal continuity were more generous to their first-round regimes. Mississippi in 1868 provided for legal continuity without casting any aspersions on the legislatures that had produced the laws then in effect. ${ }^{338}$ By referring to the laws in force, the Mississippi convention im-

331 Id.

332 Section 34 of Article XII branded null and void all debts contracted by the rebel legislature but did not mention the first-round legislature. See id $\S 34$.

333 La Const of 1868 Title X, art 148 (superseded 1898).

334 La Const of 1852 Title X, art 142 (superseded 1864).

335 La Const of 1864 Title XIII, art 148 (superseded 1868).

$336 \mathrm{La}$ Const of 1868 Title X, art 149 . Article 149 specifically excepts from its declaration of validity several acts of the first-round legislature, including parts of its Black Code. See id.

$337 \mathrm{Ga}$ Const of $1868 \mathrm{Art}$ XI, $\mathrm{cl} 3$ (superseded 1877).

338 The Mississippi constitution of 1868 provided that "[a]ll laws now in force in this State, not enacted in furtherance of secession and rebellion, and not repugnant to this constitution, shall continue in operation until they shall expire by their own limitation, or be altered or repealed by the legislature, except the hereinafter-mentioned laws," Miss Const of 1868 Sched, $\S 2$ (superseded 1890), the first of which was the December 1865 statute, no doubt designed to conciliate the Yankees, that had changed the name of Jones County to Davis County. See id. Mississippians may have believed that by default a new constitution was a legal jubilee, because an identical provision, minus any exceptions, appeared in the schedule to their constitution of 1832 . 
plied that, whatever their source, they were indeed in force. North Carolina's 1868 constitution provided that "the laws of North Carolina, not repugnant to this constitution or to the Constitution and laws of the United States, shall be in force until lawfully altered." ${ }^{\text {,399 }}$ It is possible that the North Carolina convention believed, despite what Congress said, that the first-round government had been fully lawful and that it was engaged in ordinary state-level constitutional change that did not rest on any defect in the prior constitution. North Carolina's second-round Supreme Court, however, did not take that view. It characterized the presidentially-reconstructed government as provisional and the congressionally-reconstructed government as permanent, emphasizing both continuity and change.

Florida's constitution of 1868 was by implication relatively flattering to the first-round government. Its transition provision affirmed all "acts and resolutions of the general assembly, and all official acts of the civil officers of the State," that were consistent with it and with federal law. ${ }^{341}$ It was much less charitable to the acts of the "so-called general assembly" passed after January 10,1861 , the date on which Florida's ordinance of secession was adopted. ${ }^{342}$ In particular, the 1868 constitution purported to repudiate most debts contracted in the name of Florida between the date of secession and October 25, 1865, the date on which Florida's first-round convention met at President Johnson's call. ${ }^{343}$ For all one could tell, the first-round regime was simply valid, and not just de facto.

In similar fashion, Virginia's second-round convention may have acted on the premise that whatever Congress said, the Pierpont government had been truly valid and not just de facto or provisional. Virginia's 1870 constitution continued " $[\mathrm{t}]$ he common law and statute laws now in force, not repugnant to this constitution" as if they were indeed in force. ${ }^{344} \mathrm{~A}$ much stronger endorsement of Pierpont and his coadjutors came in the preamble, which recited Virginia's earlier constitutions of $1776,1830,1850$, and 1864 , the last of which was written and adopted by a small group of loyalists meeting in Alexandria. ${ }^{345}$ It seems likely that as far as Virginia's second-round reconstructors were

Miss Const of 1832 Sched, $\S 4$ (superseded 1868).

339 NC Const of 1868 Art IV, $\$ 24$ (superseded 1876).

340 The second-round Supreme Court of North Carolina explained that the permanent government under the new constitution was the fulfillment of the provisional government. See State v Jarvis, 63 NC 556, 557 (1869).

341 Fla Const of 1868 Art XVI, $\$ 2$ (superseded 1885).

342 Id $\$ 3$.

343 Id $\$ 4$.

344 Va Const of 1870 Sched, $\$ 1$ (superseded 1902).

345 Id Preamble. 
concerned, the Pierpont government had been the real thing. ${ }^{346}$ It is thus hard to count Virginia as recognizing the power of a merely de facto government.

Arkansas's new constitution implicitly recognized the existing regime, providing that " $[\mathrm{t}]$ he inferior courts of the State as now constituted by law, except as hereinafter provided, shall remain with the same jurisdiction as they now possess." ${ }^{, 37}$ South Carolina did not continue courts but it did continue cases, authorizing the legislature to provide for their transfer to the new judiciary; it did not require that cases be refiled. ${ }^{348}$

Judicial opinions can be more talkative than constitutions, and in 1869 the second-round Supreme Court of Alabama confronted a challenge to the legal authority of its first-round predecessor. ${ }^{349}$ Chief Justice Peck, presiding over the second-round court, agreed that President Johnson lacked the authority to reorganize the state governments and therefore should have left the matter to Congress. ${ }^{350}$ Nevertheless, Peck believed the earlier government exercised actual authority and was recognized by the Reconstruction Acts as provisional and not void, although illegal. ${ }^{351}$ Nor did it matter that the judges of the first-round Supreme Court may have been ineligible to hold their offices because of their participation in the rebellion: "so long as they were permitted to hold their offices, and to discharge the duties of a supreme court, their judgments were valid, as it regards the parties to such judgments themselves, third persons and the public." ${ }^{, 352}$ Chief Justice Peck did not use the words de facto, but that was his reasoning: the earlier regime was the actual government and Congress, the final arbiter, did not completely displace it.

If de facto authority is the key here, one ratification is still in trouble. In February 1865 a Virginia legislature sitting in Alexandria

346 Whatever its faults, the 1864 Virginia constitution was the work of Loyalists. The Alexandria convention may not have been truly representative, but unlike the Johnson conventions it could not be said to have been dominated by unrepentant rebels.

347 Ark Const of 1868 Art VII, $\S 5$ (superseded 1874). While it did not repudiate the firstround regime, the 1868 Arkansas constitution did declare null and void ab initio the ordinance of secession and the state's Confederate constitution and government. See id Art I, § 25 .

348 SC Const of 1868 Art XIV, $\$ 9$ (superseded 1895).

349 Powell v Boon \& Booth, 43 Ala 459, 487-88 (1869) (holding judgments of the courts under the provisional government of Alabama were binding).

350 Id at 473.

351 Id at $477-79$. Peck thought that he was bound by Congress's judgment on this political question. See id at 478 .

352 Id at 482.

353 The passage just discussed may have been dictum, or an alternate holding, because the court also relied on a continuity ordinance of the second-round Alabama convention that endorsed what had gone before. See id at 483 (quoting Ordinance No 15). For my purposes, the important thing is that a second-round judge like Peck thought this reasoning persuasive, not that it was his holding. 
ratified the Thirteenth Amendment. ${ }^{354}$ After the creation of West Virginia, the Pierpont government had little practical authority.

It is possible to make Governor Pierpont look like Governor Dorr, the loser in a political struggle for the people's hearts and minds and hence for practical authority based on acquiescence. If this were just a matter of internal Virginia politics, the Alexandria regime's lack of de facto control likely would be fatal to its claim to speak for Virginia. But the organization in Richmond was in rebellion against the United States. Governor Letcher, unlike Governor King of Rhode Island, did not claim to lead one of the United States; only Pierpont did. Hence the question here is not the Luther question of identifying the lawful government of one of the United States. Rather, the question is the effect of a temporarily successful rebellion against the Union on the legal authority of a loyal state government.

When Congress and the President had to decide whether to admit West Virginia, and thereby recognize the Wheeling regime, the question was whether treason, even by a majority, should be allowed to interfere with the political rights of the loyal minority. ${ }^{356}$ The majority in Congress and the President sided with the loyal minority. If a rump government was all Virginia's loyalists could muster, they were at least entitled to that. This argument that the Constitution does not favor rebels has substantial appeal.

Moreover, the domestic violence clause indicates that a state government can retain its legal authority even when its practical authority is for some time disrupted. ${ }^{357}$ A sudden outburst of violence might, perhaps for a brief time, lead to anarchy. But if the state's authorities were thereby deprived of their ability to speak for it, neither the Governor nor the legislature could make the constitutionally requisite call on the United States for assistance. As long as they struck quickly and thoroughly, violent rebels could subvert the government simply through their violence. On this theory, Dorr failed because he was not ruthless enough.

354 Ambler, Pierpont at 227 (cited in note 17).

355 That authority was limited to the Eastern Shore, Alexandria, Fairfax, and Loudon counties in Northern Virginia, and a few tidewater counties. Id at 213. Although a relatively small part of Virginia, their population was hardly negligible, amounting to about a quarter of a million people. But the Pierpont government performed only limited functions even in these areas. See id at 222 ("A bitter controversy with the military decreased the popularity and impaired the usefulness of the Alexandria Government which was at no time popular with Virginians, even those of their number who remained loyal."); id at 227 ("Notwithstanding the Governor's wise recommendations and his evidences of ability to deal with an unprecedented situation, the assembly enacted no laws of importance.").

356 See Nicolay and Hay, ed, 8 Works of Abraham Lincoln at 157-60 (cited in note 33) (opinion of President Lincoln).

357 US Const Art IV, $\S 4$ (On application of legislature or governor, the United States is to protect each state against domestic violence.). 
When opposition to its authority is plainly unlawful, a state government is entitled to some time while order is being restored. It took time in Virginia, but eventually the rebellion was put down and Francis Pierpont was established in Richmond as Governor. In the interim he was the only United State Governor Virginia had, and likely his organization was entitled to speak for the state despite its limited de facto authority.

The de facto principle is reasonably well established. It remains to be discussed whether its rationale applies in the context of constitutional amendments. To see why it does, we need to examine the considerations that underlie the de facto principle. Governments are serious business. ${ }^{38}$ To say that an organization is a de facto government is to say that it actually exercises enormous power over people's lives. That power creates strong incentives to act as if the government is indeed lawful, which of course will be what its officials claim (like Justice Catron, no one wants to be a usurper). People are thus very likely to build their lives on the assumption that what the government says will stick. It is thus immensely disruptive to conclude, perhaps years later, that a once de facto government was merely de facto and void. Justice Swayne discussed this in Phillips, and he may very well have been consciously echoing Luther. In the latter case Chief Justice Taney had emphasized the grave consequences of finding retrospectively that an operational government had been legally void.

358 The Supreme Court's best reminder of the business governments are in may be a remark by Justice Catron in his concurrence in Dred Scott. Scott v Sanford ("Dred Scott"), 60 US 393 (19 How), 522-33 (1857) (Catron concurring). While Catron agreed with Chief Justice Taney's conclusion, he did not go along with all of the reasoning. In particular, he rejected the suggestion that Congress's power over territories under Article IV was confined to the territory the country owned when the Constitution was formed, and therefore did not extend to the Louisiana Purchase. Catron was assigned the western circuit, and had long ridden the circuit in land sold to the country by Napoleon.

It is due to myself to say, that it is asking much of a judge, who has for nearly twenty years been exercising jurisdiction, from the western Missouri line to the Rocky Mountains, and, on this understanding of the Constitution, inflicting the extreme penalty of death for crimes committed where the direct legislation of Congress was the only rule, to agree that he had been all the while acting in mistake, and as an usurper.

Id at 522-33.

359 Luther, 48 US at $38-39$ :

For, if this court is authorized to enter upon this inquiry as proposed by the plaintiff, and it should be decided that the charter government had no legal existence during the period of time above mentioned, - if it had been annulled by the adoption of the opposing government, - then the laws passed by its legislature during that time were nullities; its taxes wrongfully collected; its salaries and compensation to its officers illegally paid; its public accounts improperly settled; and the judgments and sentences of its courts in civil and criminal cases null and void, and the officers who carried their decisions into operation answerable as trespassers, if not in some cases as criminals.

When the decision of this court might lead to such resuits, it becomes its duty to examine 
Sandbagging people like that will have high ex post costs. One could think that the worst scenario is thus one in which the later conclusion that the government was invalid comes as a surprise. That may be true, but the anticipation that such a thing could happen is likely to have its own bad consequences ex ante. The possibility that some future regime will find the current regime void does not substitute for the current regime here and now; it does not provide some alternative way to make a contract or a marriage, to provide public goods through taxation, or deter crime by punishing criminals. It simply makes all those things less reliable and even dangerous. Ex ante, then, the anticipation of later invalidation can paralyze much of life, imposing the costs of anarchy.

These considerations are as strong with respect to constitutional amendments as any other government action, perhaps stronger. Precisely because constitutional amendments can be about fundamental issues, retrospectively invalidating one could defeat expectations wholesale. Uprooting the Sixteenth Amendment, for example, would have incalculable consequences. ${ }^{300}$ In similar fashion, the inability to settle a basic question is very costly. Doubt about the legal effectiveness of the state governments that ratified the Twelfth Amendment, for example, would introduce uncertainty as to the legality of presidential elections. ${ }^{361}$ Adjusting to that uncertainty would put the country back some.

Reconstruction and its aftermath provide two vivid examples of the de facto principle's power. West Virginia was created in a legally doubtful fashion. Yet it was created, and in fact its government exercised power both domestically and in the national lawmaking process. Later to treat all that as invalid would be a massive penalty for the country.

As the example about the Twelfth Amendment reminds us, the whole system of the national government depends on the President of the United States. Without him laws and treaties cannot be made, judges and justices cannot be appointed. In 1876 and 1877 there was serious doubt as to who had been elected President. Rival slates of electors presented themselves in enough states to swing the choice between Hayes and Tilden. Eventually Congress came up with a political mechanism for deciding the issue. ${ }^{362}$ Neither Congress nor anyone else,

very carefully its own powers before it undertakes to exercise jurisdiction.

360 "The Congress shall have power to lay and collect taxes on incomes, from whatever source derived, without apportionment among the several States, and without regard to any census or enumeration." US Const Amend XVI.

361 US Const Amend XII (reforming the mechanism for electing the President and Vice President and providing for a congressional vote when no candidate has a majority).

362 See Charles Fairman, 7 History of the Supreme Court of the United States: Five Justices 
however, has any explicit power with respect to the presidency that resembles each house's power with respect to its own members. To this day no one really knows whether Hayes or Tilden was rightfully elected. But Hayes took the oath and became, in fact, President of the United States. His vetoes, not Tilden's, were legally effective. Any other result would have had unacceptable consequences.

\section{Federal coercion.}

Congress and President Johnson have been accused of coercing southern ratification of the Fourteenth and Thirteenth Amendments. Ratification was the result of threats to engage in unlawful conduct, goes the argument, and actions taken under such threat are themselves legally inoperative.

a) Was there coercion that mattered? Although it is easy to talk about federal coercion, it is not actually clear that there was any that made a difference. Four of the southern states that ratified the Thirteenth Amendment did so with no explicit encouragement from the federal government. The loyalist regimes of Virginia, Louisiana, Arkansas, and Tennessee, which ratified in early 1865, were not pressed to do so and did not need any pressure. Each of those governments already had eliminated slavery in its own state, not because the war was lost, but because they were in the hands of Unionists.

When President Johnson was overseeing the reconstruction process in the six states that got organized in the second half of 1865, he made fairly clear that ratification would be a good idea. ${ }^{365}$ The main inducement he offered, however, was not his to give and he did not claim that it was. Ratification, he indicated, would be necessary to induce Congress to treat the states as restored. ${ }^{366}$ While that was almost certainly true, Johnson was not acting in concert with Congress as a legal institution nor with the Republican leadership. Rather than making a threat, he was pointing out a way to curry favor with the decisionmaker. No doubt many southerners hoped that ratification would smooth the process of restoration to representation, but they had received no coercive offer from Congress with those terms.

and the Electoral Commission of 1877 53-54 (Macmillan Supp 1988) (summarizing the passage of the Electoral Commission Act of January 29, 1877).

363 This accusation is separate from the claim that federal pressure induced the states to form their reconstructed governments. That claim is dealt with in the preceding section.

364 The principle has its home in the law of contract. Old common law doctrine on the subject is discussed in Chitty, Contracts at 167-70 (cited in note 228), and nineteenth-century American developments in Parsons, 1 Law of Contracts at 321-22 (cited in note 228). The current Restatement contains a similar doctrine. Restatement (Second) of Contracts $\$ \$ 174-76$ (1981) (discussing how threat and duress can void a contract).

365 See Richardson, ed, 6 Messages and Papers of the Presidents at 358 (cited in note 14).

366 See id at 358-60. 
Eventually they did receive such an offer in the first Reconstruction Act. Ratification of the Fourteenth Amendment was made a condition to representation in Congress. ${ }^{367}$ It is doubtful, however, whether that particular threat was necessary. The coalitions that dominated most of the second-round governments had excellent reasons to ratify, including, for example, protection of their black constituents from renewed Black Codes. ${ }^{368}$ Congress had done the real work when it brought about the creation of state governments with race-blind suffrage.

b) Was the coercion unlawful? Not all agreements made under threat are invalid. Lawful "threats" in contract bargaining include the threat not to enter into the contract if the other party will not agree to one's terms. ${ }^{369}$ Such inducements are lawful because the parties are under no obligation to one another to agree. Duress comes from a threat to do something unlawful. ${ }^{370}$ No doubt most Republicans had come to believe that exclusion of the southerners was lawful, and in particular that it was lawful to demand security for the Union before they were readmitted. Part of that security was the Fourteenth Amendment.

Whether they were right or not is one of the tightly-wound knots I will not try to unravel here. It is important to see, however, that this action probably had to be treated as lawful whether it was or not. Behind the political dynamics of Reconstruction and the inducement offered by the statutes was a fact of power founded in a basic point of constitutional law: each house of Congress decides whom to admit, and there is nothing anyone else can do about that decision. ${ }^{371}$ While it

367 See 14 Stat at 429 ("[W] hen said State ... shall have adopted [the Fourteenth Amendment] and when said article shall become a part of the Constitution of the United States, said State shall be declared entitled to representation in Congress.").

368 Not all the second-round governments were dominated by mainstream Republicans. Virginia's was not. See Jack P. Maddex, Jr., The Virginia Conservatives 1867-1979: A Study in Reconstruction Politics 67-85 (UNC 1970) (describing coalition of Democrats, ex-Whigs, and Republicans that controlled Virginia's second-round government). In Georgia white supremacists had enough power to declare the elected black members of the legislature ineligible on account of color. See Thompson, Reconstruction In Georgia at 211-14 (cited in note 183) (reporting the resolution to unseat the black members passed by a vote of $83-23$; the black members did not vote).

369 "An ordinary offer to make a contract commonly involves an implicit threat by one party, the offeror, not to make the contract unless his terms are accepted by the other party, the offeree. Such threats are accepted as part of the bargaining process." Restatement (Second) of Contracts $\S 176$, cmt a.

370 See id $\$ \$ 175,176$ (a) (stating that a threat is improper and may give rise to voidability under the duress principle if it is a crime or a tort).

371 This is why it was important to the Republicans in 1866 to retain an absolute majority of all congressional seats, counting the excluded southerners. As long as the Republicans had that majority, a body of southerners and northern Democrats could not even claim to muster the quorum necessary to act as Congress. With that absolute majority, and control of each house, the Republicans held in their hands the fate of the southern claimants. 
was official Republican doctrine that decisions as to the identity of lawful state governments were for Congress collectively, the ultimate power over admission was in the House and Senate separately. The determination of majorities of each of those bodies to keep out the southerners was the real whip for the southern states.

As the Constitution says, each house is the judge of the elections, qualifications, and returns of its own members. ${ }^{3 / 2}$ Whether or not one agrees with Luther and the doctrine that Congress is final when it identifies the lawful government of a state, Section 5 of Article I gives the House and Senate the final authority to resolve contested questions of law and fact; that is what judges do. And once judgment is entered it is treated as correct whether it is or not; that is the main thing judges do. The House and Senate are the final tribunal, and appeal to them is the final remedy for unlawful exclusion.

Which means that the southerners should not have been able to challenge the legality of either house's determination in any other forum. If the question came up collaterally in a later judicial proceeding, the court should have assumed that the congressional decision was right. Contracts entered into pursuant to lawful threats are valid. The private law analog would be something like this: $A$ and $B$ are neighbors who are negotiating a sale by $A$ to $B$ of the part of $A$ 's property closest to $B$. To help matters along, $A$ erects an unsightly temporary structure on that part of the property, which $B$ will be able to take down if the parcel changes hands. $B$ sues $A$, claiming that the structure is a nuisance, and $A$ prevails. $B$ then agrees to buy at $A$ 's price and $A$ removes the structure. Then when $A$ moves to close the sale $B$ backs out, saying that the bargain was made under duress because of the unlawful threat to maintain the ugly building. $A$ replies that the earlier litigation conclusively established that the building and

The Supreme Court's current doctrine is that the courts can do at least something about it. See Powell v McCormack, 395 US 486, 550 (1969) (Courts may decide whether exclusion from the House of Representatives was legally permissible.). I think it safe to say that the Court that decided Mississippi v Johnson, 71 US (4 Wall) 475 (1867), would have disagreed. The Court in the latter case denied its own jurisdiction to hear a bill by Mississippi's first-round government to enjoin the President from executing the Reconstruction Acts. Id at 499-501.

372 See US Const Art I, $\S 5$. The two houses' finality regarding their own membership also answers the objection that by excluding the southerners the Republicans were violating not only the Qualifications Clauses, id Art I, $\S 2 \mathrm{cl} 2$; id $\S 3$, cl 3, by adding new qualifications of their own, but also the Constitution's most fundamental principle, that each state is entitled to representation in the Senate. See id Art I, $\S 3, \mathrm{cl} 1$ (two senators from each state); id Amend V (No amendment may deprive any state of equal suffrage in the Senate without its consent.). The Republicans' position was that they were not adding qualifications, but rather were refusing to seat pretended representatives and senators who had not been validly elected. On their theory the Senate was no more violating the Constitution in refusing to seat Alexander Stephens than it would have been in refusing to seat a claimant who had been chosen only by one house of a bicameral state legislature. Whether Stephens had been validly elected was a bitterly contested question, but one as to which the Senate was "the Judge." Id Art I, § 5 . 
the threat were lawful. On that point $A$ prevails on preclusion grounds.

c) Coercion and Article $V$. The foregoing argument leaves unresolved the main question: whether unlawful political threats invalidate constitutional amendments when, absent the threat, the amendment would not have been adopted. I think such threats do not, despite what may seem like the obvious analogy to the private law of contract.

Constitutional amendments are not contracts. They are exercises of sovereign power. Illegal acts that affect such exercises may or may not render them invalid. A classic instance of a binding legislative act that may have resulted from unlawful conduct is found in Fletcher $v$ Peck. ${ }^{333}$ Fletcher involved a Georgia statute that sought to undo a massive land grant that had been obtained by bribing the previous legislature. The Supreme Court held the subsequent statute invalid, thus settling the law and protecting third parties (who may or may not have been innocent), at the price of giving legal effect to a grossly wrongful action. ${ }^{374}$ In order to decide whether Article V implicitly contains a duress exception, it is necessary to think about Article $V$, not just about general principles concerning coerced action.

Thinking about Article V suggests that it has no implicit duress limitation, just as it has no explicit duress limitation. It is useful here to consider two candidate thirteenth amendments that did not make it. During the secession winter of 1860 to 1861 , efforts were made to hold the Union together. One came from the lame duck session of the Thirty-sixth Congress. That Congress mustered the two-thirds majorities to propose the so-called Corwin amendment, which would have cemented slavery in the states. ${ }^{375}$ Lincoln supported the amendment in his first inaugural address. ${ }^{376}$ Senator Corwin's proposal was a concession to the South designed to end secession and keep the Union together.

Not quite two years later, in his annual message of December 1862, President Lincoln endorsed another suggested constitutional amendment dealing with slavery. ${ }^{37}$ It too was a concession to the South, although after the already-terrible war the terms were not as juicy. Rather than protecting slavery for as long as the Constitution should last, it provided federal money to compensate slaveholders in

37310 US (6 Cranch) 87 (1810).

374 Id at 139.

375 "No amendment shall be made to the Constitution which will authorize or give to Congress the power to abolish or interfere, within any State, with the domestic institutions thereof, including that of persons held to labor or service by the laws of said State." McPherson, Rebellion at 59 (cited in note 18 ).

376 Richardson, ed, 6 Messages and Papers of the Presidents at 10-11 (cited in note 14).

377 Id at 136. 
states that arranged to emancipate their slaves before 1900 . It also secured the freedom of those slaves who had been emancipated by the war, while providing compensation for loyal owners. ${ }^{378}$

As far as Lincoln and most Republicans were concerned, secession was unlawful and civil war to make secession stick was treason. Yet supporters of the two amendments were prepared to buy the southerners off; their proposed amendments were bribes designed to dissuade the South from lawless behavior. They would not have been able to make either offer, however, had there been a strong duress principle in Article V. Both proposed amendments were made in response to action that many of their proponents thought to be illegal. Hence if duress invalidated constitutional amendments, both would have run a good chance of later being held invalid. To be sure, the southerners thought that they were within their rights in seceding and in enforcing secession through war, but Lincoln and his party disagreed. With a duress principle in place, President Lincoln would have been hard put to it to tell the southerners that the conciliatory amendments would hold good. In hindsight we know that they would not have. Lincoln's Chief Justice would hold that secession was unlawful. ${ }^{379}$

Bitter political and legal disputes like slavery may lead the parties to take steps like secession that are themselves a subject of bitter political and legal dispute. If constitutional amendments are invalid when made in response to unlawful threats and unlawful conduct, the amendment process can lock up just when it would be most helpful. Saving the Union may be worth some duress.

A natural response to this argument is to distinguish some threats from others and in particular to distinguish strategic from nonstrategic threats. A strategic threat is one made only in order to induce agreement, with no other motive behind it. When a stranger who has nothing against you personally says, "your money or your life," the threat is strategic. Such threats will be deterred if the wrongdoer cannot later enforce the agreement, because the only reason to make the threat is to obtain the agreement. When your clan's hereditary enemy says, "I'm going to kill you," the threatened action is attractive to the threatener on its own merits. That threat is non-strategic. If that enemy wants your head but would like $\$ 1,000,000$ even more, then being able to pay the money would be very useful. And if it is possible to distinguish strategic from non-strategic threats, allowing targets to buy

378 Id.

379 That was the holding of Texas $v$ White. See 74 US at 726 (declaring Texas's "ordinance of secession ... and all the acts of her legislature intended to give effect to that ordinance, were absolutely null"). 
off non-strategic threateners like the hereditary enemy will not increase the number of threats.

A sensible duress doctrine under Article $V$ probably would distinguish between strategic and non-strategic threats, because the former are much more subject to deterrence through invalidity than are the latter. Under this more limited duress doctrine it is possible to argue that the proposed thirteenth amendments would have been unproblematic because the South's behavior was non-strategic. Secession was an independently motivated response to Lincoln's election, not an attempt to extort further concessions from the North. It could not have been deterred by invalidating any constitutional amendments that resulted from it, and hence the secession crisis could have been defused through an amendment.

If Article $\mathrm{V}$ has this kind of duress principle, it is doubtful whether the Fourteenth Amendment was the product of duress. The possibly unlawful threat was exclusion of the southerners from Congress, and that threat probably was non-strategic. It is easy to lose track of the sequence of events with respect to the Fourteenth Amendment, and come to believe that the Republicans were trying to force ratification and hit upon exclusion as a means to do so. That was not the order in which matters developed. Rather, the Republican leadership agreed in the fall of 1865 that it would be unsafe to admit the southern claimants. ${ }^{380}$ As events unfolded in the winter of 1865 to 1866 , the Republicans became increasingly convinced that admitting the southerners would mean allowing the rebels to win politically what they had lost on the battlefield. The Fourteenth Amendment, with its Section 2 penalty aimed at the neo-slave-power, set out the conditions under which the South could safely be restored. Throughout this period, the driving force of exclusion was the desire to maintain loyal (or Republican, if one thinks it was really about partisan power) control of Congress. The Republicans had an excellent independent reason to keep southern Democrats out, so their mode of coercion very likely was not strategic.

Moreover, even the limited duress principle has a difficulty that makes it an unappealing reading of Article V. It requires that decisionmakers be able to distinguish strategic from non-strategic threats in situations where the threat was not carried out, or was not carried out fully. If the Corwin Amendment had been adopted and the Union saved, and a Republican Congress had later tried to back out on grounds of duress, it would have been necessary to know whether the threat of secession had been strategic. For Americans spared the Civil War, that would have been a difficult question. Many Republicans in 
1860 and 1861 seem to have thought that secession was just a southern bluff in an attempt to extract further concessions. ${ }^{381}$ Politicians who believed that could not in good faith have offered the Corwin Amendment had there been an Article $\mathrm{V}$ duress doctrine, because it would run a serious risk of invalidity were the threat found to be unlawful and strategic. Once again, a duress doctrine would cause the constitutional amendment process to break down when the country needed it most.

Sometimes the need for final and certain settlement overcomes other considerations. Constitutions are fundamental law, and they can include compromises on strongly contested issues. Those compromises can avert something worse and have to stick if they are going to do so. A similar need for conclusive agreement appears in public international law, which has its own doctrine of duress with respect to treaties. In general, if one state coerces another into agreeing to a treaty, the treaty is invalid. ${ }^{382}$ Despite that principle, the United States does not have to give California back to Mexico, because the principle has an exception. Coerced peace treaties are binding. ${ }^{383}$ This may seem upside-down, because peace treaties above all others are the result of plain military force, as was the Treaty of Guadalupe Hidalgo which included the Mexican Cession. But a state that cannot bind itself to surrender risks being obliterated. ${ }^{384}$ A country that cannot amend its constitution in response to illegal conduct may run that risk too.

\section{FORMALISM AND CONSTITUTIONAL AMENDMENT}

All the foregoing leaves in place a basic historical fact. In the 1860 s a sectionally based party used its control over the national legislature and the state legislatures of its section to bring about constitutional change. The sectional party did that despite the opposition of another sectional coalition that started out in political control of more

381 As Potter explains, "there was an overwhelming impulse in the North to discount the signals from the South and to suppose that South Carolina was merely having another temper tantrum." Potter, The Impending Crisis at 517 (footnote omitted) (cited in note 16).

382 Henry J. Wheaton, Elements of International Law $\$ 267$ at 340 (Sampson Low 8th ed 1866) (Richard Henry Dana, ed) (In general, treaties obtained through threat of force are void, like contracts made under similar threat.).

383 Id.

384 Wheaton elaborated:

On the other hand, the welfare of society requires that the engagements entered into by a nation under such duress as is implied by the defeat of its military forces, the distress of its people, and the occupation of its territories by an enemy, should be held binding; for if they were not, wars could only be terminated by the utter subjugation and ruin of the weaker party.

Id. 
than one-fourth of the states. The Republicans, that is, got away with something Article $\mathrm{V}$ probably was supposed to prevent.

This is no problem for a formalist. Legal rules often fail to accomplish their purposes. To say that the rule and its reason diverge is to identify a problem with the rule, but it demonstrates neither that on balance the rule is a bad one nor that it has been misapplied.

Many find that kind of response unpersuasive as a general matter, in large measure because they reject, not the claim that a norm can fail its reason, but the tendency of many formalists to read norms so that they do so. The problem is not conceptual but interpretive. Granted that norms can poorly serve their purposes, it is nevertheless a problem with an interpretation that it causes the norm to miss its mark. This difficulty may seem especially serious when the norm being interpreted is the Constitution's very rule of recognition, the keystone of the legal arch. If Article V misses its mark, the whole Constitution is in jeopardy.

This is a serious objection, but it does have an answer. In Hans Linde's phrase, behind the features of the norms that here seem to defeat their purpose there is still "a reason that even realists can respect. ${ }^{365}$ The aspects of the Constitution that in this context conspire against state autonomy have their own powerful justification. The justification is the leading reason for preferring rules over standards: the need for certainty.

If one concludes as I do that the reduced denominator theory is ultimately unpersuasive, and if one still has doubts as to the lawfulness of congressional reconstruction, the case in favor of the Amendments rests on two of three arguments. The Amendments are valid if Congress may finally determine a state government to be lawful and if Article $\mathrm{V}$ ignores political duress, or if de facto governments are legally effective and there is no duress exception. The question of duress arises specifically with respect to Article V, whereas both the Luther principle and the de facto government principle apply throughout the constitutional system, coming into play whenever it is necessary to identify the lawful government of a State. All three find their justification in terms of certainty. As I argued, if Article V has an implicit antiduress doctrine, its application becomes fuzzier. In similar fashion, both the recognition power and the de facto government principle are driven by the overwhelming need to identify with certainty the effective government of a state. Thus we need to know both whether Arti-

385 "The first amendment, however, is addressed expressly to lawmakers. . . Attention to text earns only professional scorn in constitutional law. But when one among many constitutional limitations is literally directed against law-making, might the text perhaps embody a reason that even realists can respect?" Hans A. Linde, "Clear and Present Danger" Reexamined: Dissonance in the Brandenburg Concerto, 22 Stan L Rev 1163, 1175 (1970). 
cle $\mathrm{V}$ itself can plausibly be read as a fairly formalistic provision, so that such purpose-defeating norms can apply to it, and whether the Constitution as a whole has strongly formalistic features, so that it would purchase certainty at the expense of more substantive goals like state autonomy.

One reason to believe that Article $\mathrm{V}$ in particular makes that trade-off in favor of clarity is that it pretty clearly does so in other contexts. A classic example involves the operation of the three-fourths requirement. As Ackerman explains, that number daunted the New Dealers when they considered putting their reforms into a constitutional amendment. ${ }^{386}$ It did so even though President Roosevelt's support was regionally quite broad. The problem was that one-fourthplus-one of the states (the blocking minority) is only a proxy for onefourth of the people, and it can be a very bad proxy. As FDR explained in a fireside chat, there was a blocking minority of thirteen states that contained five percent of the nation's population. ${ }^{387}$ The voters in those thirteen states did not have to be unanimous in their opposition, nor indeed did a majority of them have to be opposed. All that was necessary was for "powerful economic interests" to influence enough legislators to defeat the amendment, through fear-mongering public relations campaigns or crass political log-rolling or some even less savory method. ${ }^{388}$ In practice, Article $\mathrm{V}$ can give a veto to a handful of fat cats who can influence a tiny population in a small number of states. It is hard to believe that the Constitution was designed to do that. This is a side effect of the rule's formality: it says "three-fourths of the States," not "significant minority, and especially a significant minority that coheres regionally."

It works the other way too. Just as Article $\mathrm{V}$ empowers blocking minorities that are too small under any plausible view of its purpose, it empowers enacting majorities that are likewise too small. A political movement that is lucky in its location in space, time, or the space of political preferences can enact an amendment that does not reflect a long-term consensus of the substantial bulk of the politically active people. In space the key is geographical distribution. A movement that is thinly spread over a lot of congressional districts but virtually unrepresented in many others can fall well short of being a two-thirds national majority while nevertheless commanding a two-thirds majority in the House. If the movement is also fortunate in narrowly controlling many low-population states, it can have two-thirds of the Senate and three-fourths of the state legislatures. 
Another way to get lucky is to seize the moment in time, pushing an amendment through Congress and the states when unusually favorable conditions temporarily prevail. This may well be the story of the Eighteenth Amendment, proposed during World War I when prohibitionist fervor peaked. ${ }^{399}$ Another useful tactic is a willingness to be a single-issue voter, refusing to support any candidate who is not sound on the single issue. ${ }^{300}$ If there are enough such voters to swing an election, the candidates of both major parties are likely to take the pledge. A favorable location in the space of political preferences can magnify an intense minority's interest on its favorite issue.

All these are consequences of Article V's formalities. If the provision's purpose is to require a stable, regionally distributed, national supermajority for constitutional amendments, the formalities can defeat the purpose. That is a problem, but so is a constitutional amendment provision that is too much of a standard and not enough of a rule. Norms that seek certainty have a natural home in Article V.

Moreover, both the Luther doctrine and the de facto government principle can reasonably be attributed to the Constitution as a whole. With respect to Luther, the question is whether the Constitution can really give a final decider the power to identify the lawful government of a state. In the pathological case, a two-thirds majority of Congress would declare some group gathered in a bar-room to be the government of California, and the United States Army would support it against the "rebels" who had elected the real governor and legislature in Sacramento. That is a lot of finality to give to any institution's judgment.

While the natural temptation in response is to point to the finality claimed by the Supreme Court, a better answer is the finality explicitly found in the Constitution. ${ }^{391}$ The Senate has "the sole Power to try all Impeachments." ${ }^{392}$ If two-thirds of the senators convict the President of high crimes and misdemeanors, the President is removed. If two-thirds of the senators convict the President on patently trumped up charges,

389 See Kendrick A. Clements, The Presidency of Woodrow Wilson 256 (Kansas 1992) (Moral reformists, including Prohibitionists, used the war to push through their proposals.). Prohibition war hysteria seems to have been like other forms of war hysteria: "The war made it easy for drys to portray the predominantly German American brewers as subversives, if not traitors." Richard F. Hamm, Shaping the Eighteenth Amendment 240 (North Carolina 1995). On this account, prohibition was adopted in a moment of national intoxication and repealed when the country sobered up.

390 Hamm points out that a distinctive feature of the Anti-Saloon League, in contrast to the Prohibition Party, was its willingness to work with drys from all parties. Hamm, Shaping the Eighteenth Amendment at 132 (cited in note 389).

391 The Court claims final interpretive authority with respect to abstract questions of federal law, not just particular cases. See Cooper v Aaron, 358 US 1, 18 (1958) (Supreme Court's interpretation of the Constitution is itself the supreme law of the land.).

392 US Const Art I, \$ 3, cl 6. 
the President is removed. ${ }^{393}$ The reason is easy enough to see: the last thing the country needs is a doubt as to who is President.

Perhaps the most striking historical lesson of We the People: Transformations is that the identity of the President mattirs even more than we normally think, and we normally think it matters quite a lot. $^{334}$ As the events of 1865 to 1869 demonstrate, a change in the presidency can swing the nation's destiny. Yet the Constitution confers finality on a fallible, political institution charged with deciding whether to remove a President. It is no stretch to think that the same Constitution allows both houses together, either acting with the President or overriding him with a two-thirds majority, to decide whether a political organization is the government of a state.

While the de facto government principle does not identify a final decider, it is nevertheless a finality norm and rests in part on the rationale common to such norms: the need for certainty. To think that such norms are consistent with the underlying purpose of a constitution, one need only think that certainty is an important purpose of constitutions. That should not be a hard sell. For example, arguing in favor of the finality rule of Cooper $v$ Aaron, ${ }^{395}$ two leading theorists emphasize finality as the very purpose of law as such.

393 The Senate is final and there is no judicial review. The best explanation remains Charles L. Black, Jr., Impeachment: A Handbook 54 (Yale 1974) ("I don't think I possess the resources of rhetoric adequate to characterizing the absurdity of that position [that there could be judicial review]."). The Court's doctrine is that impeachment is a political question in the sense that the relevant political branch, the Senate, has the last word. See Nixon v United States, 506 US 224, 229-36 (1993). Justice Souter concurred in the judgment in Nixon, arguing that under certain circumstances there may be judicial review of an impeachment conviction. See id at 253-54. Justice Souter did not, however, indicate that there would be any review of a Supreme Court decision reviewing an impeachment conviction, so his suggestion would simply replace one final decider with another.

394 Meditating on the alternate past in which Lincoln served out his second term, Ackerman concludes,

[a]ll we do know is that John Wilkes Booth deprived Lincoln of his chance to steer Reconstruction to a conclusion, leaving Johnson to generate a fact-pattern that occurs with sufficient frequency to merit a special name: the Vice-Presidential exception. The pattern arises because. ... of the need to maximize [a Presidential candidate's] electoral chances by "balancing the ticket" with a Vice-Presidential nominee who appeals to a different constituency. This means that the death of a President ... typically yields the succession of somebody very different.

Ackerman, 2 We the People at 276 (cited in note 8).

395358 US at 18.

396 Alexander and Schauer explain the importance of finality:

Law, therefore, provides the benefits of authoritative settlement, as well as the related but still content-independent benefits of inducing socially beneficial cooperative behavior and providing solutions to Prisoners' Dilemmas and other problems of coordination. These considerations not only provide a justification for the existence of law, but also a justification for obeying it, by giving agents reasons to obey laws with which they disagree.

Larry Alexander and Frederick Schauer, On Extrajudicial Constitutional Interpretation, 110 Harv 
Another leading theorist whose work underlines the importance of clear settlement by constitutions is Bruce Ackerman. His story is built around the iron frame of American political history under the Constitution of 1787 , the federal electoral schedule. ${ }^{397}$ That schedule comes from the most rule-like kind of constitutional provision, that kind that uses numbers. ${ }^{398}$ As Ackerman has seen so clearly, the certainty those numbers induce runs through American politics. It too is a fundamental feature of the constitutional design. Less definite terms could better serve some other purpose, but those in the Constitution well serve the purpose of letting everyone know when the next election is coming.

Clarity and certainty are in substantial measure what this Constitution is about, and both the Luther doctrine and the de facto principle serve those ends. They are thus entirely plausible principles from the standpoint of the Constitution's purpose, even though they may subvert other purposes like state autonomy. Certainty can be more important than more substantive goals. Sometimes the spirit killeth, and the letter giveth life.

L Rev 1359, 1371 (1997).

397 Ackerman reveals his reliance on the electoral schedule in the following passage:

As the organizing power of ordinary legality declines, Americans discover that the Constitution contains deeper imperatives that continue to shape their struggle for power and legitimacy.

Two in particular. The first is the electoral calendar, which has proceeded remorselessly for two hundred years. Even when protagonists challenge existing rules and principles, they are well aware that the voters' judgment will not be long delayed.

Ackerman, 2 We the People at 384 (cited in note 8) (citations omitted).

398 See US Const Art I, $\$ 2$ (House of Representatives composed of "Members chosen every second Year."); id § 3, cl 1 (senators chosen for six years); id $\S 3$, cl 2 (senatorial term classes staggered so that one-third of Senate turns over every two years); id Art II, $\S 1$, cl 1 (President shall "hold his Office during the Term of four Years."). 